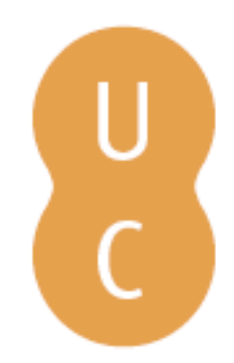

\title{
nommalina
}

\section{Em torno das relações entre o direito da família e o direito das sucessões - 0 caso particular dos pactos sucessórios no direito internacional privado}

\author{
Autor(es): $\quad$ Silva, Nuno Ascensão \\ Publicado por: Imprensa da Universidade de Coimbra \\ URL \\ persistente: URI:http://hdl.handle.net/10316.2/38891 \\ DOI: $\quad$ DOI:http://dx.doi.org/10.14195/978-989-26-1113-6_13 \\ Accessed : $\quad$ 26-Apr-2023 10:27:14
}

A navegação consulta e descarregamento dos títulos inseridos nas Bibliotecas Digitais UC Digitalis, UC Pombalina e UC Impactum, pressupõem a aceitação plena e sem reservas dos Termos e Condições de Uso destas Bibliotecas Digitais, disponíveis em https://digitalis.uc.pt/pt-pt/termos.

Conforme exposto nos referidos Termos e Condições de Uso, o descarregamento de títulos de acesso restrito requer uma licença válida de autorização devendo o utilizador aceder ao(s) documento(s) a partir de um endereço de IP da instituição detentora da supramencionada licença.

Ao utilizador é apenas permitido o descarregamento para uso pessoal, pelo que o emprego do(s) título(s) descarregado(s) para outro fim, designadamente comercial, carece de autorização do respetivo autor ou editor da obra.

Na medida em que todas as obras da UC Digitalis se encontram protegidas pelo Código do Direito de Autor e Direitos Conexos e demais legislação aplicável, toda a cópia, parcial ou total, deste documento, nos casos em que é legalmente admitida, deverá conter ou fazer-se acompanhar por este aviso.

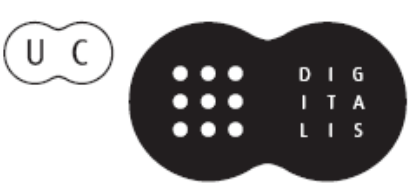




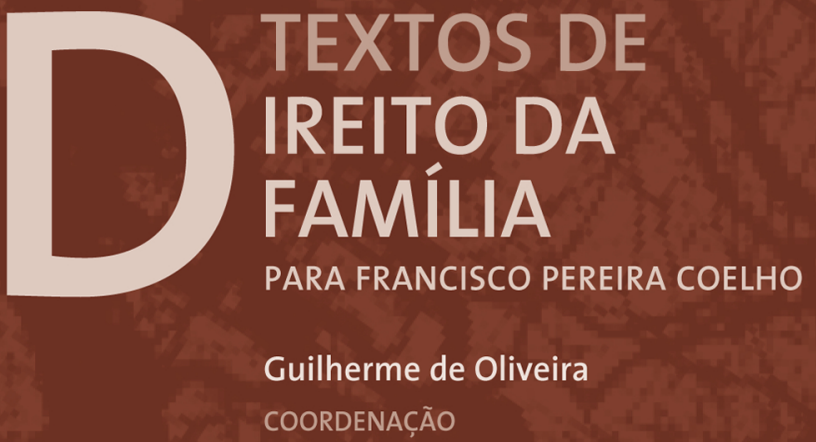




\section{EM TORNO DAS RELAÇÕES ENTRE O DIREITO DA FAMÍLAA E DIREITO DAS SUCESSÕES - O CASO PARTICULAR DOS PACTOS SUCESSÓRIOS NO DIREITO INTERNACIONAL PRIVADO}

Nuno Ascensão Silva Assistente Convidado na Faculdade de Direito da Universidade de Coimbra

\section{I - Introdução}

1. Se o direito é, como há muito aprendemos com CASTANHEIRA NEVES, "apenas uma solução possível para um problema necessário"2,

1 Tendo em consideração as limitações de espaço que rodeiam uma publicação desta índole, omitimos aqui parte significativa das reflexões complementares e das referências bibliográficas a que fomos conduzidos no decurso da presente investigação. Todavia, muitas destas encontram-se contidas em N. ASCENSÃo SILVA, "A sucessão testamentária no direito internacional privado - Algumas considerações", Cadernos do Cenor, n. ${ }^{\circ} 4$ (em publicação), pelo que, desde já, para aí remetemos in toto, ali podendo procurar-se, por conseguinte, tanto o fundamento de muito daquilo que aqui secamente afirmamos como a explicitação das soluções gerais (materiais e conflituais) mais relevantes concernentes à sucessão - mormente, à sucessão voluntária - e que aqui, por economia de linhas, apenas podemos sumariamente convocar.

Acresce ainda que a referência a qualquer disposição legal sem a menção da sua origem deverá considerar-se feita aos preceitos do Código Civil português, salvo se outra coisa resultar com evidência do contexto em que alguma delas se encontre inserida.

2 A. CASTAnheira Neves, "O direito como alternativa humana. Notas sobre o problema actual do direito", Digesta (Escritos acerca do Direito, do Pensamento Jurídico, da sua Metodologia e Outros), Coimbra: Coimbra Editora, 1995, v. I, p. 299.

Para uma interpelante e cuidada reflexão sobre as alternativas ao direito, e considerando o distinguo da juridicidade no mundo contemporâneo, cf.: A. CASTANHEIRA 
também se afigura seguro que qualquer sistema de regulamentação social que pretenda assumir-se, no contexto do nosso horizonte civilizacional, como um autêntico ordenamento jurídico haverá de predicar-se por uma específica unidade de sentido $^{3}$ e que, hic et nunc, e independentemente da diversidade muitas vezes incidental dos critérios legais acolhidos nos distintos corpos jurídicos nacionais, se vai densificando num lastro significativo de princípios normativos ${ }^{4}$.

Todavia, e para além da unidade do direito qua tale (the unity of law), são incontáveis as convergências, sobreposições e espaços de contacto que, de um modo mais ou menos notório, e em termos

NEVES, "O direito como validade", RLJ [Revista de Legislação e de Jurisprudência], ano $143 .^{\circ}$ (2013-2014), p. 154 ss.; IDEM, "O direito como alternativa humana...", cit., p. 287 ss.; IDEM, "O Direito hoje: uma sobrevivência ou uma renovada exigência", $R L J$, ano $139 .^{\circ}$ (2009-2010), p. 202 ss.; IDEM, "O problema da universalidade do Direito - ou o Direito hoje, na diferença e no encontro humano-dialogante das culturas", Internacionalização do direito no novo século, Jorge de Figueiredo Dias (org.), Coimbra: Coimbra Editora, 2009, p. 45 ss.; e F. PINTO BRONZE, Lições de introdução ao direito, 2. ${ }^{a}$ ed., Coimbra: Coimbra Editora, 2010 (reimpressão), p. 572 ss.

3 Sobre o sentido específico do direito e a unidade intencional que, no contexto do nosso espaço civilizacional, o constitui, vide, entre nós: A. CASTANHEIRA NEVES, Curso de introdução ao estudo do direito, Coimbra: [s.n.], 1971-1972, p. 44 ss.; IDEM, "Justiça e direito", Digesta, v. I, cit., p. 273 ss.; F. PINTO BRONZE, op. cit., p. 459 ss. $\mathrm{E}$, para o modo como tal problema foi assumido tanto na época pré-moderna como sob a égide do positivismo jurídico, cf. ainda F. PINTO BRONZE, op. cit., p. 307 ss. e elementos bibliográficos aí indicados.

Por fim, para mais desenvolvimentos sobre a unidade do sistema jurídico e com uma ampla reflexão sobre a sua composição e relevância metodológica, cf. ainda: A. CASTANHeira Neves, "A unidade do sistema jurídico: o seu problema e o seu sentido (Diálogo com Kelsen)", Estudos em Homenagem ao Prof. Doutor J. J. Teixeira Ribeiro, v. II, Coimbra: [s.n.], 1979, p. 73 ss.; IDEM, Curso..., cit., pp. 265 ss., 331 ss.; F. PINTO BRONZE, op. cit., p. 607 ss.

${ }^{4}$ Particularmente sobre os princípios normativos e com o esclarecimento cabal da sua função fundamentante no contexto de um constituendo sistema jurídico, vide, entre nós: A. CASTANHeira Neves, Curso..., cit., esp. p. 331 ss.; IDEM, "O sentido actual da metodologia jurídica”, Digesta (Escritos acerca do Direito, do Pensamento Jurídico, da sua Metodologia e Outros), v. III, Coimbra: Coimbra Editora, 2008, esp. pp. 394 ss. e 410 s.; IDEM, Metodologia jurídica: problemas fundamentais, Coimbra: Coimbra Editora, 1993, p. 188 ss.; F. PINTO BRONZE, op. cit., p. 627 ss.; e, ainda, J. J. Gomes CANOTILHO, "Princípios. Entre a sabedoria e a aprendizagem", Ars iudicandi. Estudos em Homenagem ao Prof. Doutor António Castanheira Neves, Jorge de Figueiredo Dias, José J. Gomes Canotilho e José de Faria Costa (org.), v. I (Filosofia, Teoria e Metodologia), Coimbra: Coimbra Editora, 2008, p. 375 ss. 
mais particulares, entretecem os diversos sectores que a dogmática jurídica, atendendo às particulares e devenientes exigências que materialmente os constituem, foi paulatinamente autonomizando no contexto do corpus iuris.

É certo que tais fenómenos, e que são o eco, na verdade, de uma comunhão intencional mais ou menos cristalina, vêm à epifania nos diversos momentos históricos de um modo diferenciado e nem sempre a sua cabal amplitude consegue ser apreendida pelos juristas, pelo menos pelos mais desatentos. Realmente, a empresa de tentar compreender a fenomenologia, mas, sobretudo, o sentido das mutáveis tendências de confluência, justaposição, dependência e osmose que convocamos nem sempre se revela fácil, tudo dependendo, desde logo, dos específicos domínios jurídicos tidos em vista, resultando até especialmente espinhosa quando o olhar comparatístico ousa perfilar ordenamentos jurídicos internos diversos.

2. Em qualquer caso, a dificuldade da análise que alvitrámos nunca impediu de se traçarem inúmeras ligações ou afinidades entre o direito da família e o direito das sucessões5.

\footnotetext{
5 Sobre as relações entre o direito da família e o das sucessões (e vice-versa), vide, por exemplo, e com ampla demonstração de tais interdependências no seio do nosso direito positivo: D. LEITE DE CAMPOS, Lições de direito da família e das sucessões, 2. ${ }^{a}$ ed., Coimbra: Almedina, 1997, p. 28 s.; J. DUARTE PINHEIRO, O direito das sucessões contemporâneo, Lisboa: AAFDL, 2011, p. 47 ss.; C. PAMPLONA CORTE-REAL, Direito da Família e das Sucessões (relatório apresentado no concurso para professor associado da Faculdade de Direito de Lisboa (DR, II série, $n .^{\circ} 235$, de 11/10/94), nos termos do artigo $44 .^{\circ}, n .^{\circ} 2$, do Estatuto da Carreira docente Universitária e relativo a programa, conteúdo e métodos de ensino da disciplina de Direito da Família e das Sucessões), Lisboa: Lex, 1995, pp. 35 ss., 48 ss.; R. CAPELO DE SOUSA, "As Partes Especiais dos Direitos da Família e das Sucessões, a Parte Geral e as Partes Especiais no Código Civil”, Comemorações dos 35 anos do Código Civil e dos 25 anos da Reforma de 1977, v. I (Direito da família e das sucessões), Coimbra: Coimbra Editora, 2004, p. 901 ss.

Por outro lado, e considerando as relações destas duas disciplinas com a Parte Geral do Código Civil, o direito das obrigações e o direito das coisas, veja-se também R. CAPELO DE SOUSA, "As Partes Especiais ...", cit., p. 894 ss. (ainda para uma ilustração de tais interdependências intra-sistemáticas, embora tendo em vista apenas o direito da família, M. R. LOBO XAVIER, "Das relações entre o Direito comum
} 
Com efeito, e não obstante as diferenças que ditam a multissecular independência destes dois domínios jurídicos e que fundamentam, por isso, a sua emancipação, conseguimos perscrutar quase espontaneamente a existência de um espaço referencial comum, consubstanciado em multiformes e recíprocas dependências, o que nos faz crer na existência de um fio condutor que os entrelaça e que desde logo se demonstra na proeminência de um "modelo familiar" do direito das sucessões ${ }^{6}$. E isto, na verdade, independentemente de se concordar com a autonomia científica das disciplinas que ao seu estudo se dedicam ou, ao invés, o que pode justificar a recente evolução do plano curricular de muitos estudos universitários, se sugerir a tendencial dissolução do direito das sucessões no direito patrimonial da família ${ }^{7}$ - privilegiando desta maneira um ponto de

e o Direito matrimonial - a propósito de atribuições patrimoniais entre cônjuges", Comemorações dos 35 anos..., v. I, cit. p. 487 ss.).

${ }^{6}$ Cf. F. Pereira Coelho, Direito das sucessões, Coimbra: [s.n.], 1992, p. 29 s. Para uma síntese dos sistemas sucessórios, cf. ainda, e para a caracterização do paradigma sucessório português, F. PEREIRA COELHO, op. cit., p. 28 ss.; R. CAPELO DE SOUSA, Direito da família e das sucessões: relatório sobre o programa, o conteúdo e os métodos de ensino de tal disciplina, Coimbra: [s.n.], 1999, p. 33 ss.; IDEM, Lições de direito das sucessões, $4^{{ }^{a}}{ }^{\text {ed }}$. renovada, Coimbra: Coimbra Editora, 2013, v. I, p. 98 ss.; L. CARVALHO FERNANDES, Teoria geral do direito civil, $6{ }^{a}{ }^{a}$ ed. revista e actualizada, v. I (Introdução. Pressupostos da relação jurídica), Lisboa: Universidade Católica Portuguesa, 2012, p. 103 ss.; IDEM, Lições de direito das sucessões, $4 .^{a}$ ed. rev. e actual., Lisboa: Quid Juris, 2012, p. 31 ss.; C. PAMPLONA CORTE-REAL, Curso de direito das sucessões, Lisboa: Quid Juris, 2012, p. 168 ss.

${ }^{7}$ Se é conhecida a tendência para o estudo do direito (patrimonial) da família e das sucessões constituir o conteúdo de uma única disciplina universitária, ainda que muitas vezes por motivações aparentemente conjunturais, certo é que se tem procurado apresentar razões de fundo para tal junção e que não se apartam significativamente daquelas a que aludimos no texto. Sobre esta questão, vejam-se, por exemplo: C. PAMPlona CORTE-ReAl, Direito da Família..., cit., pp. 12 s., 19 s., 28 ss., 167 s.; R. CAPELO DE SOUSA, Direito da família..., cit., p. 50 s.

Na verdade, e partindo da observação segundo a qual “... o Direito das Sucessões é, em grande parte, elemento integrante do estatuto patrimonial da família, dado que os bens, por morte do seu titular, circulam pelos canais do casamento e do parentesco" (D. LEITE DE CAMPOS, Direito da família e das sucessões (relatório), Coimbra: Almedina, 1998, p. 111), a referida dissolução do direito das sucessões no âmbito do direito patrimonial da família tem sido defendida entre nós por D. LEITE DE CAMPOS (por exemplo, Lições..., cit., esp. p. 377 ss.), uma vez que, situando-o no quadro da regulamentação das relações de família, tem sustentado que o regime 
vista que pressente no regime da sucessão mortis causa o fundamental desiderato de prover, à semelhança daquilo que acontece com o regime patrimonial do casamento, à organização das relações de cariz pecuniário no espaço familiar - ou, pelo menos, a sua primacial consideração como um dos múltiplos instrumentos de programação patrimonial dos sujeitos individuais - estudado a par, por isso, das doações e dos regimes de bens do casamento ${ }^{8}$. Neste mesmo sen-

das relações patrimoniais da família deve abranger o regime de bens do casamento e a sucessão mortis causa.

Todavia, tal perspectiva tem sido contrariada por parte significativa da nossa doutrina, que sublinha, desde logo, a especificidade da regulamentação sucessória relativamente ao direito da família (por exemplo, C. PAMPLONA CORTE-REAL, Direito da Família..., cit., esp. pp. 20, 32 ss.; J. DUARTE PINHEIRO, op. cit., p. 49 ss.), questionando-se mesmo, atendendo à sua relativa autonomia científica e didáctica, a possibilidade de logradamente se efectuar um estudo simultâneo (e não meramente sucessivo ou acoplado) das matérias que integram as referidas disciplinas (assim, por exemplo, R. CAPELO DE SOUSA, Direito da família..., cit., p. 53 ss.; C. PAMPLONA CORTE-REAL, Direito da família..., cit., p. 167).

8 Com efeito, tal perspectiva, e que se centra no carácter patrimonial de todos os factos jurídicos a que aludimos, encontra claro acolhimento na civilística francesa. Na verdade, o tratamento jurídico conjunto das matérias relativas à sucessão legal (Título I), às doações (liberalidades inter vivos) e testamentos (Título II) e aos regimes de bens do casamento (Título V) corresponde afinal à sistematização do Código Napoleónico, uma vez que todas elas são reguladas, conquanto em títulos diversos, e ganhando por isso autonomia, no seu Livro III (Des différentes manières dont on acquiert la propriété).

Por sua vez, no Código civil português de 1867, todas as matérias a que nos referimos eram tratadas na Parte II (Da aquisição de direitos), embora com uma cisão clara entre "os direitos originários que se adquirem por vontade própria e de outrem conjunctamente" - aqui se incluindo o regime de bens de casamento, as doações aos esposados (feitas entre si ou por terceiros) e as doações entre cônjuges [Livro II, Título II (Dos contratos em particular), Capítulo I (Do casamento)] e "os direitos que se adquirem por mero facto de outrem e dos que se adquirem por simples disposição da lei" - e onde se encontrava estabelecido o regime das sucessões (legal e testamentária) (Livro III, Título II) -, pelo que não se poderá afirmar com inteira propriedade, como o faz EDUARDO DOS SANTOS (Direito das sucessões, 2. ${ }^{a}$ ed., Lisboa: AAFDL, 2002, p. 22), que "o CC Português de 1867 adoptou a sistematização do CC francês".

Em suma, o Código de Seabra, embora assumindo um critério fundamentalmente antropocêntrico, conquanto marcadamente patrimonialista, não sancionou por inteiro a sistemática do Code civil - Des personnes, Des biens et des différentes modifications de la propriété e Des différentes manières dont on acquiert la propriété -, tanto mais que não decalcou a clássica trilogia das Institutiones, se bem que, no tangente ao conteúdo das soluções, haja bebido na codificação gaulesa tanto o princípio da 
tido, e sem que tal implique a negação da autonomia dos sectores normativos a que nos referimos, são ainda de destacar as vozes de todos aqueles que, da proximidade do regime jurídico das sucessões e das doações (inter vivos e mortis causa), apontam a imprescindível mobilização de um aparato jurídico-dogmático comum e, portanto, a conveniência na construção de uma teoria geral das liberalidades 9 .

Seja como for, e mesmo no âmbito da tradicional dicotomia - direito da família versus direito das sucessões -, sempre os civilistas mais ilustres, cultivando até concomitantemente as duas disciplinas - é o caso do Professor Pereira Coelho, que assumiu tal encargo durante largos anos na Faculdade de Direito da Universidade de Coimbra -, nunca renunciaram, perspicazmente e à medida da evolução jurídica, à inacabada tarefa de ir reconstituindo o fio de Ariadne que perpassa os mencionados sectores normativos - função que abraçam, ao contrário de Sísifo, não por punição dos deuses, mas antes pelo propósito voluntariamente assumido de tornar o mundo do direito (normativamente) inteligível - só assim se podendo dar cumprimento ao munus eminentemente prático de que o jurista se encontra investido -, e cujo fruto decerto não se assemelha aos trabalhos do ofensor dos deuses e manhoso enganador de Hades, condenado ad aeternum, no Tártaro, a um labor rotineiro, interminável e destituído de proveito.

3. Obviamente, não temos a pretensão de buscar aqui as múltiplas conexões que em geral existem entre o direito da família e o direito

imutabilidade dos regimes de bens do casamento como a proibição, que até levou mais longe, dos pactos sobre sucessão futura.

${ }^{9}$ Assim, J. DUARTE Pinheiro, op. cit., p. 501 ss., e que defende tudo aconselhar a um tratamento "global e unitário" dos negócios jurídicos gratuitos, ou seja, dos testamentos e das doações inter vivos - e cuja relevância sucessória se manifesta, desde logo, na necessidade de estas serem tidas em conta por ocasião do cálculo do montante da herança legitimária e contratual - e mortis causa - de natureza predominantemente sucessória -, convocando para isso o exemplo da sistemática adoptada no Code civil e no Código Civil italiano. 
das sucessões, nem muito menos tentar a sua fundamentação ou apontar as consequências perniciosas que a exclusiva consideração das soluções em que se corporiza cada uma dessas disciplinas tantas vezes resultado de uma visão imediatista, desconhecedora das "coerências invisíveis" e das silenciosas forças motrizes que, sem embargo de ímpetos contrários, centripetamente as enleiam, e consumada frequentemente através de reformas legislativas parciais acaba por desencadear ${ }^{10}$. Caso contrário, e se nos envolvêssemos por agora em tal tarefa, impor-se-ia arcar o estudo de um vasto leque de complexos problemas jurídicos que a articulação do regime sucessório com o direito da família suscita, passando naturalmente, desde logo, por exemplo, pela consideração crítica do modo como a tutela dos elementos da família do de cuius determina os critérios legais acolhidos no âmbito da sucessão legítima e legitimária ${ }^{11}$ - e a que

10 Pensamos, por exemplo, no modo como a tutela sucessória excessiva do cônjuge sobrevivo, a demonstrar uma inequívoca valorização da família conjugal por ocasião das transmissões mortis causa, acabará ora por travar o casamento em segundas núpcias do cônjuge supérstite ora por se tornar no motivo, caso exista um segundo matrimónio, da perturbação da paz da vida familiar e do surgimento de litígios com os descendentes.

E, na verdade, na nossa doutrina tem-se defendido estarmos face a uma protecção "exagerada" (por exemplo, D. LEITE DE CAMPOS, Lições..., cit., p. 604 ss.; IDEM, Direito da família e das sucessões (relatório), cit., p. 130) e até "obstinada" (assim, C. PAMPlONA CORTE-REAL, "Os efeitos sucessórios do casamento", Direito da família e política social [actas do Congresso Internacional organizado de 1 a 3 de Outubro de 1998 pela Faculdade de Direito da Universidade Católica Portuguesa (Porto)], Maria Clara Sottomayor e Maria João Tomé (org.), Porto: Publicações Universidade Católica, 2001, p. 63), desadequação que, efectivamente, a evolução da realidade sociológica da família tem vindo a confirmar [vide, por exemplo, embora sem incidir directamente sobre o direito português, F. AMATO, Crisi del matrimonio e coniuge superstite: gli assegni spettanti al coniuge superstite nella crisi del rapporto matrimoniale, Napoli: Edizioni Scientifiche Italiane, 1999, passim; e, entre nós, recentemente, e acompanhando a nossa melhor doutrina, P. TÁVORA VíTOR/R. CÂNDIDO MARTINS, "Depois de a morte nos separar - a protecção do cônjuge sobrevivo da perspectiva da responsabilidade", Estudos em homenagem ao Prof. Doutor José Joaquim Gomes Canotilho, Fernando Alves Correia... [et al.] (org.), Coimbra: Coimbra Editora, 2012, v. I, p. 753 ss.], solicitando-se, por conseguinte, uma revisão do estatuto sucessório do supérstite.

11 Uma vez que, esclarece C. PAMPLONA CORTE-REAL, "Os efeitos sucessórios...", cit., p. 55 ss. (ver também IDEM, Direito da Família..., cit., p. 145 s.), "a tutela qualitativa das quotas hereditárias, e em especial dos legitimários e da quota di- 
correspondem inelutáveis constrições ao princípio da livre disposição mortis causa dos bens -, pela apreciação do sentido jus-familiar dos mecanismos de protecção sucessória do cônjuge supérstite ${ }^{12}$ ou, até, e agora tendo em mente problemas técnico-jurídicos mais específicos, pela análise das incidências sucessórias de institutos - como é o caso das doações propter nuptias e das doações entre os cônjuges - que obtêm no seio do direito da família um tratamento muito particu$\operatorname{lar}^{13}$. Labor que, na verdade, e alargando o âmbito da nossa tarefa à regulamentação das situações da vida privada transfronteiriça, se tornaria por agora ainda mais insuportável, caso ambicionássemos perscrutar as possíveis irradiações de todas estas sinapses no seio do funcionamento do método conflitual14.

sponível, afectam o giro patrimonial mortis causa, determinando eventuais situações de pulverização do património do causante."

12 Com efeito, o reforço da posição sucessória do cônjuge supérstite tem o inequívoco significado de uma valorização da família conjugal no contexto do regime jurídico geral das relações de família (para mais desenvolvimentos, veja-se, particularmente, C. PAMPlONA CORTE-REAl, Direito da Família..., cit., p. 135 ss.). Por outro lado, aspecto a que voltaremos, o equilíbrio do sistema passa pela consideração conjunta do estatuto sucessório do cônjuge sobrevivo e dos regimes de bens do casamento, mormente do regime supletivo (vide infra, n. 14).

13 Seja como for, se a relevância sucessória das doações é particularmente evidente no caso das liberalidades mortis causa (por exemplo, os pactos sucessórios), ou seja, naquelas que, "produzindo efeitos só após a morte do autor, encontram nela a sua causa" (para mais desenvolvimentos sobre esta distinção, vide M. C. Pimenta COElho, "A imputação de liberalidades feitas ao cônjuge do autor da sucessão”, Estudos em Homenagem ao Professor Doutor Inocêncio Galvão Telles, António Menezes Cordeiro, Luís Menezes Leitão e Januário da Costa Gomes (org.), Coimbra: Almedina, v. IV, 2003, p. 527 ss.), também as liberalidades feitas inter vivos por um dos cônjuges ao outro têm uma inquestionável incidência do ponto de vista do direito das sucessões (pense-se, por exemplo, no problema da colação, caso se entenda que também o cônjuge está obrigado a conferir os bens que haja recebido a título gratuito, ou na sua redução por inoficiosidade).

14 O problema da conservação das "sinapses" entre o direito da família e o direito das sucessões é particularmente visível quando debatemos no plano do direito internacional privado a sucessão legitimária ou a protecção do cônjuge sobrevivo.

Quanto à primeira questão, e partindo do princípio segundo o qual os limites emergentes para a autonomia individual da sucessão legitimária decorrem da mobilização da lex successionis, sempre se poderá dizer que nem sempre esta deverá, quando implique a denegação de uma quota indisponível a certos herdeiros, ser automaticamente considerada contrária à ordem pública internacional, impondo-se 
Ao invés, cingir-nos-emos antes à questão da sucessão contratual e às relações que podem discernir-se entre o seu regime jurídico e a organização patrimonial da família, mais especificamente, o regime

na aferição da existência de uma postergação insuportável dos valores fundamentais do ordenamento jurídico do foro atender ao disposto pela lex familiae. Com efeito, afigura-se-nos que esta deverá ser ponderada aquando da determinação dos deveres de solidariedade familiar que vinculam o de cuius a certos herdeiros - e cujo cumprimento não passa pelo necessário reconhecimento de uma quota indisponível, bastando, por exemplo, como acontece no Reino Unido, ao abrigo do Inheritance (Provision for Family and Dependants) Act 1975 (entretanto modificado pelo Inheritance and Trustees' Powers Act 2014, em vigor desde 1 de Outubro de 2014), que o cônjuge ou os descendentes possam obter da herança a reasonable financial provision (para uma análise aprofundada, cf. M. TRULSEN, Pflichtteilsrecht und englische family provision im Vergleich, Tübingen: Mohr Siebeck, 2004; L. WOLFF, Pflichtteilsrecht, Forced Heirship, Family Provision: Österreich, Louisiana, Schweiz, England und Wales; ein Rechtsvergleich, Frankfurt am Main... [etc.]: Lang, 2011) -, funcionando como importante elemento coadjuvante por ocasião da concretização da excepção de ordem pública internacional.

Para mais desenvolvimentos, e não olvidando que o alastramento do princípio da autonomia da vontade no domínio do direito internacional privado sucessório, para além de constituir um importante instrumento de planificação sucessória, permite amiúde, ao facultar ao de cuius a escolha da lex successionis, a frustração das expectativas hereditárias daqueles que potencialmente - isto é , caso não houvesse escolha de lei - seriam legitimários, cf., por exemplo, P. LOKIN, "Freedom of Testation and the Protection of the Family in Private International Law", The Future of Family Property in Europe, Katharina Boele-Woelki, Jo Miles and Jens M. Scherpe (ed.), Cambridge... [etc.]: Intersentia, 2011, p. 369 ss.; T. PFUnDSTEIN, Pflichtteil und ordre public: Angehörigenschutz im internationalen Erbrecht, München: Beck, 2010; N. WATTÉ, "La réserve dans les successions internationales", De erfrechtelijke reserve in vraag gesteld: Koninklijke Federatie van Belgische Notarissen, Comite voor Studie en Wetgeving: Notarieel Congres, Dendermonde, 1997 = Examen critique de la réserve successorale: Fédération royale des notaires de Belgique, Comité d'études et de législation: Congrès notarial, Termonde, 1997, Fédération royale des notaires de Belgique (éd.), Bruxelles: Bruylant, 1997, Deel I (Rechsvergelijking)/Tome I (Droit comparé), p. 367 ss.; S. LORENZ, "Internationaler Pflichteilsschutz und Reaktionen des Erbstatuts auf lebzeitige Zuwendungen”, Die Europäische Erbrechtsverordnung: Tagungsband zum wissenschaftlichen Symposium anlässlich des 20-jährigen Bestehens des Deutschen Notarinstituts am 11. Oktober 2013 in Würzburg, Anatol Dutta und Sebastian Herrler (Hrsg.), München: Beck, 2014, p. 113 ss.; P. LAGARDE, "Les principes de base du nouveau règlement européen sur les successions", Revue Critique de Droit International Privé, v. 101 (2012), p. 709 ss.

No que concerne à protecção do cônjuge sobrevivo - e não esquecendo que, mesmo no exclusivo âmbito do direito civil, a sua tutela não se esgota no reconhecimento de direitos sucessórios, havendo igualmente que considerar os específicos direitos que decorrem do funcionamento do regime patrimonial do casamento -, também o problema da sua articulação com o regime matrimonial assume particular importância por ocasião da regulamentação das situações jurídicas dotadas de elementos internacionais relevantes. 


\section{económico do casamento, atendendo de modo particular ao nosso ordenamento jurídico, sem que isto impeça considerações pontuais}

$\mathrm{Na}$ verdade, se é claro que existe no direito material uma particular ligação entre as soluções legais relativas ao regime matrimonial (mormente, o regime supletivo) e o estatuto sucessório do cônjuge supérstite e cuja ponderação se considera imperiosa por ocasião da formulação dos critérios legais, prevalecendo até o entendimento segundo o qual a protecção sucessória do cônjuge sobrevivo deverá ser reforçada nos regimes de separação e, ao invés, reduzida quando vigorar o regime da comunhão geral ou de adquiridos (reflectindo sobre esta interdependência, C. PAMPLONA CORTE-REAl, Direito da Família..., cit., esp. pp. 51 s., 144 s., J. FERNANDO NOGUEIRA, "A Reforma de 1977 e a posição sucessória do cônjuge sobrevivo", Revista da Ordem dos Advogados, ano 40 (1980), pp. 671, 688 ss.; A. DE SOUSA LEAL, A legítima do cônjuge sobrevivo. Estudo comparado hispano-português, Coimbra: Almedina, 2004, p. 113 ss.) - conquanto, entre nós, e ao contrário daquilo que acontece noutros sistemas jurídicos, a posição de meeiro e de herdeiro se encontrem autonomizadas, não dependendo os direitos sucessórios do supérstite do específico regime de bens que haja vigorado na constância do casamento -, tal coerência poderá resultar particularmente afectada pela submissão de tais questões a ordenamentos jurídicos diversos, nem sempre se revelando transparente a natureza dos concretos preceitos jurídico-materiais que em cada sistema legal organizam a tutela do cônjuge sobrevivo no momento da dissolução por morte do regime matrimonial.

Assim será, por exemplo, como acontece face ao Código Civil brasileiro, quando o chamamento sucessório do cônjuge varie em função do regime matrimonial, não concorrendo ele com os descendentes do de cuius sempre que o casamento tenha sido celebrado no regime da comunhão geral, da separação obrigatória e da comunhão parcial de bens, aqui, apenas quando a herança não integre bens particulares (cf., para uma apreciação crítica das recentes soluções brasileiras, V. MACEDO SANTOS, "A nebulosa concorrência sucessória do cônjuge com descendentes e os regimes de bens", Temas controvertidos de direito das sucessões: o cônjuge e o companheiro, Adisson Leal, Carlos Pamplona Corte-Real, Victor Macedo dos Santos (coord.), Lisboa: AAFDL, 2015, p. 89 ss.; e L. NASCIMENTO PORTUGAL, "O direito de concorrência do cônjuge casado em separação convencional”, Temas controvertidos..., cit., p. 131 ss.).

Por seu turno, também no direito alemão podemos achar lugar para as dificuldades a que aludimos, sendo suficiente para o comprovar atender desde logo ao regime jurídico da Versorgunsausgleich [a compensação dos direitos à pensão de reforma, prevista no $\S 1587$ do Bürgerliches Gesetzbuch [BGB] e regulada no Versorgungsausgleichsgesetz [VersAusglG], de 3 de Abril de 2009, com alterações], uma vez que existe um tratamento diferenciado das situações em que a liquidação do regime matrimonial ocorra por divórcio [§ 20 ss., VersAusglG] daquelas em que esta venha a suceder por morte de um dos cônjuges, caso em que a pretensão do supérstite se dirige contra os herdeiros ( $\$ 31$, I, VersAusglG). Para uma exposição do regime da Versorgunsausgleich no direito teutónico, vide, por exemplo, F. RULAND, Versorgungsausgleich, 3. Aufl., München: Beck, 2011; Versorgungsausgleich, Rolf Sethe, Armin Höland und Notarkammer Sachsen-Anhalt (Hrsg.), Baden-Baden: Nomos Verlagsgesellschaft, 2011; N. DETHLOFF, Familienrecht, 29. Aufl., München: Beck, 2009, p. 216 ss.; D. SCHWAB, Familienrecht, 17. Aufl., München: Beck, 2009, p. 449 ss.; versando a questão do ponto de vista do direito internacional privado alemão, vejam-se ainda: R. WAGNER, Versorgungsausgleich mit Auslandsberührung, 
a propósito de sistemas jurídicos estrangeiros, tendo em vista a cabal explicitação do significado das soluções entre nós sancionadas.

Bielefeld: Verlag Ernst und Werner Gieseking, 1996; A. DÖRFLER, Durchfübrung des Versorgungsausgleichs in Auslandsfällen unter besonderer Berücksichtigung des New Yorker Equitable Distribution Law von 1980, Heidelberg: [s.n.], 1995; D. HOCHHEIM, Versorgungsausgleich und IPR: Der Versorgungsausgleich in der gesetzlichen Rentenversicherung vor und nach dem Beitritt Polens zur EU, Hamburg: Verlag Dr. Kovac, 2004; W. KRETSCHMANN, Versorgungsausgleich auf der Grundlage eines ausländischen Rechts: die völker- und kollisionsrechtliche Problematik des Art. 17 Abs. 3 EGBGB und ibre Bewältigung, dargestellt am Beispiel des Schweizer Rechts, Aachen: Shaker, 2005; C. NOLTE-SCHWARTING, Der Versorgungsausgleich in Fällen mit Auslandsberübrungen, Berlin: Duncker \& Humblot, 1984; H. J. SONNENBERGER, "Der Versorgungsausgleich im Internationalen Privatrecht", Festschrift für Günther Beitzke zum 70. Geburtstag am 26. April 1979, Otto Sandrock (Hrsg.), Berlin/NewYork: Walter de Gruyter, 1979, p. 739 ss.; G. SCHOTTEN/C. SCHMELLENKAMP, Das Internationale Privatrecht in der notariellen Praxis, 2., neu bearb. Aufl., München: Beck, 2007, p. 210 ss.; K. SIEHR, "Vermögensstatut und Geldausgleich im IPR - Gilt Art. 3 Abs. 3 EGBGB auch für den Pflichtteil, den Zugewinnausgleich und den Versorgungsausgleich?”, Balancing of Interests: Liber amicorum Peter Hay zum 70. Geburtstag, Hans-Eric Rasmussen-Bonne... [et al.] (Hrsg.), Frankfurt am Main: Verl. Recht und Wirtschaft, 2005, p. 389 ss., esp. p. 398 ss. Sobre o problema da titularidade do direito à pensão de reforma em geral, cf., entre nós, F. PEREIRA COELHO/ Guilherme DE Oliveira, Curso de direito da família, 4. ${ }^{a}$ ed., v. I (Introdução. Direito matrimonial), Coimbra: Coimbra Editora, 2008, p. 544, e ainda, com ampla informação comparatística, M. J. VAZ TOMÉ, $O$ direito à pensão de reforma enquanto bem comum do casal, Coimbra: Coimbra Editora, 1997, passim.

Por outro lado, ainda no direito alemão, se a quota hereditária do cônjuge sobrevivo corresponde, quando concorre com descendentes, a 1/4 da herança ( $\$ 1931$, I, BGB), o $\$ 1371$, I, estabelece ainda o aumento automático de $1 / 4$ no quadro do regime matrimonial supletivo ( $\$ 1363$ ), a Zugewinngemeinschaf [e que consiste num regime híbrido, uma vez que, se na constância do casamento vigora a separação, na sua dissolução por morte é reconhecido a cada um dos cônjuges um crédito de participação no enriquecimento ou ganhos obtidos pelo outro (Ausgleichanspruch)], sendo de realçar que este $1 / 4$ acresce aos direitos sucessórios do cônjuge ab intestato determinados de acordo com o $§ 1931$ e é independente da existência efectiva de tais ganhos, uma vez que é calculado de acordo com o valor da herança. De qualquer forma, e para além desta "legítima grande", que opera somente nos casos em que o supérstite é efectivamente herdeiro ou legatário, reconhece-se na Zugewinngemeinschaf uma "legítima pequena", correspondente à legítima normal ( $\S 2303$ e 1931), a que acresce o Zugewinnausgleich (caso isso decorra das regras do regime matrimonial, por força do $\S 1373$ ss.), e aplicável em caso de preterição do legitimário ( $\$ 1371$, II) ou de repúdio da herança (\$1371, III) [cf., para a caracterização do regime supletivo alemão, N. DETHLOFF, op. cit., p. 115 ss.; D. SCHWAB, op. cit., pp. 104 ss., 126 ss.; F. STURM, "La Zugewinngemeinschafi et les régimes conventionnels du droit allemand", Les régimes matrimoniaux en droit comparé et en droit international privé (Actes du Colloque de Lausanne du 30 septembre 2005), Andrea Bonomi et Marco Steiner (éd.), Genève: Droz, 2006, p. 79 ss.; e, entre nós, C. PAmplona CORTE-REAl, Direito da Família..., cit., p. 136 s.; discutindo as 
Por conseguinte, no feixe das situações em que o facto designativo sucessório é constituído por uma ou mais manifestações de vontade negocial (sucessão voluntária), atenderemos apenas aos pactos suces-

virtualidades de tal sistema do ponto de vista da harmonização do direito matrimonial europeu, vide ainda G. BRUDERMÜLLER, "Zugewinngemeinschaft: Struktur und Reform”, Die Zugewinngemeinschaft- ein europäisches Modell?, Volker Lipp, Eva Schumann und Barbara Veit (Hrsg.), Göttingen: Universitätsverlag Göttingen, 2009, p. 3 ss.; J. SEEVOGEL, Der Wablgüterstand der Gütertrennung für die Europäische Ehe: Eine rechtsvergleichende Betrachtung der Zugewinngemeinschaft des deutschen Rechts und der ehelichen Güterstände der Gütertrennung in Spanien unter besonderer Berücksichtigung der Ausgleichsansprüche bei Beendigung der Ehe, Bielefeld: Gieseking, 2012). Deste modo, ao discernirmos no direito alemão duas vias - a "erbrechtilche Lösung", decorrente do § 1371, I, e consistente num aumento a forfait da legítima do cônjuge sobrevivo, e a "güterrechtliche Lösung", caso em que, por conseguinte, não sendo o supérstite herdeiro, não há lugar ao regime sucessório do Zugewinnausgleichs, cabendo-lhe apenas os direitos decorrentes do regime de bens, nos termos do $§ 1372$ ss. -, evidencia-se também aqui a íntima ligação entre o regime matrimonial e a tutela sucessória do supérstite (D. SCHWAB, op. cit., p. 152 s.; N. DEThloff, op. cit., p. 140 ss.), problema que tem suscitado do ponto do direito internacional privado alemão particular interesse, dando lugar a uma farta jurisprudência [sobre o problema da qualificação do § 1731, I, do BGB, e numa bibliografia extensíssima, cf. K. SIEHR, op. cit., esp. p. 395 ss.; G. KEGEL/K. SCHURIG, Internationales Privatrecht, 9. Aufl., München: C. H. Beck, 2004, p. 1006; D. LOOSCHELDERS, Internationales Privatrecht - Art. 3-46 EGBGB, Berlin/Heidelberg: Springer, 2004, p. 233; C. VON BAR, Internationales Privatrecht, München, C. H. Beck, Bd. II (Besonderer Teil), 1991, p. 162 ss.; G. SCHOTTEN/C. SCHMELLENKAMP, op. cit., pp. 189, 301 ss.; e, tendo em vista o novo regime europeu das sucessões internacionais, B. KOWALCZYK, "Die Zukunfstperspektiven der Anwendung des $\S$ 1371 I BGB unter der Geltung des europäischen Kollisionsrechts”, Zeitschrift für Rechtsvergleichung, Internationales Privatrecht und Europarecht [ZfRV], v. 54 (2013), p. 126 ss.]. E, para um tratamento aprofundado dos problemas suscitados pela tutela sucessória do cônjuge supérstite no contexto da vida privada internacional, destacamos ainda: M. ZABALO ESCUDERO, La situación jurídica del cónyuge viudo. Estudio en el derecho internacional privado y derecho interregional, Pamplona: Aranzadi, 1993; W. HERING, Die gesetzlichen Rechte des überlebenden Ehegatten in deutsch-kanadischen Erbfallen: eine Untersuchung zur gesetzlichen Regelung der Rechte des überlebenden Ehegatten im kanadischen Recht und zur internationalprivatrechtlichen Lösung deutsch-kanadischer Erbfälle, München: C.H. Beck, 1984; M. CLAUSNITZER, Die güter- und erbrechtliche Stellung des überlebenden Ehegatten nach den Kollisionsrechten der Bundesrepublik Deutschland und der USA - Eine rechtsvergleichende Untersuchung $z u$ Normenwiderspruch und Anpassung im Internationalen Privatrecht, Konstanz: Hartung-Gorre Verlag, 1986; D. HENRICH, "Ehegattenerbrecht und IPR (2000)", Deutsches, ausländisches und internationales Familien- und Erbrecht: ausgewählte Beiträge, Bielefeld: Gieseking, 2006, p. 327 ss.; B. KOWALCZYK, Die gesetzlichen Rechte des überlebenden Ehegatten im deutsch-polnischen Rechtsverkehr unter Berücksichtigung des europäischen Rechts, Hamburg: Kovač, 2013. 
sórios e que são, na definição lata de COELHO DA ROCHA ${ }^{15}$, "todos aquelles, que têm por objecto a herança de uma pessoa ainda viva, ou seja a de algum dos contractantes, ou seja a de terceiro". Assim, trataremos exclusivamente da sucessão pactícia (os "contratos de he-

De resto, os conflitos de qualificações entre "regime matrimonial" e "regime sucessório" são igualmente uma boa demonstração das dificuldades que convocamos, constituindo a orientação doutrinária no sentido da prevalência do primeiro uma clara indicação do favor matrimonii que teremos ocasião de referir (sobre estes conflitos, vejam-se, por exemplo, na nossa doutrina, A. FERRER CORREIA, Lições de Direito Internacional Privado, Coimbra: Almedina, 2000, pp. 236 ss., 240 ss.; e A. MARQUES DOS SANTOS, "Breves considerações sobre a adaptação em Direito Internacional Privado", Estudos de Direito Internacional Privado e de Direito Processual Civil Internacional, Coimbra: Almedina, 1998, p. 69 ss.), concitando, na verdade, agravados esforços interpretativos e abrindo-se caminho a passos largos à intervenção do expediente metodológico da adaptação [sobre esta, vide, por exemplo, A. MARQUES DOS SANTOS; "Breves considerações sobre a adaptação...", cit., p. 51 ss.; L. de LIMA PINHEIRO, Direito Internacional Privado [DIP], v. I (Introdução e Direito de Conflitos. Parte Geral), $3 .^{a}$ ed. refundida, Coimbra: Almedina, 2014, p. 600 ss.; e, na doutrina estrangeira, D. LOOSCHELDERS, Die Anpassung im internationalen Privatrecht: zur Methodik der Rechtsanwendung in Fällen mit wesentlicher Verbindung zu mebreren nicht miteinander harmonierenden Rechtsordnungen, Heidelberg: Müller, 1995].

15 Instituições de Direito Civil Portuguez, $3 .^{a}$ edição, Coimbra: Imprensa da Universidade, 1852, t. II, p. 577.

Sobre a sucessão contratual, e para mais desenvolvimentos sobre o conceito de pacto sucessório ( institutos onde a designação sucessória, e deixando por agora de parte a sucessão testamentária, acaba por ser determinada pela existência de outros factos jurídicos negociais, vide: A. COELHO DA ROCHA, op. cit., p. 577; EDUARDO CORREIA, Lições de direitos sucessórios, António Manuel da Veiga; de harmonia com as prelecções do Professor Doutor Eduardo Correia, ao curso do $4^{\circ}$ ano jurídico de 1948-49, Coimbra: [s.n.], 1949, p. 57 ss.; J. BOTELHO MONIZ, "A sucessão pactícia na lei portuguesa", O Direito, ano 78. ${ }^{\circ}$ (1946), p. 310 s.; J. DUARTE PINHEIRO, op. cit., p. 182 ss.; C. ARAÚJO DIAS, Lições de direito das sucessões, Coimbra: Almedina, 2010, pp. 35, 42 s.; I. GALVÃo TELLES, Sucessões: Parte Geral, Coimbra: Coimbra Editora, 2004, p. 19 ss.; J. de OlIVEIRA ASCENSÃO, Direito Civil - Sucessões, 5. ${ }^{a}$ ed. revista, Coimbra: Coimbra Editora, 2000, p. 92 ss.; EDUARDO DOS SANTOS, op. cit., pp. 76 s., 557; L. CARVAlho Fernandes, lições..., cit., p. 555 ss.; C. PAMPlONA CORTEREAL, Curso..., cit., p. 80 ss.

De qualquer modo, e sempre considerando a distinção entre negócios jurídicos inter vivos e mortis causa [sobre esta classificação, cf., por exemplo, M. DOMINGUES DE ANDRADE, Teoria geral da relação jurídica, v. II (Facto jurídico, em especial negócio jurídico), Coimbra: Almedina, 1964 (reimpressão), p. 44 ss.; L. CARVALHO FERNANDES, Teoria geral do direito civil, $5 .^{a}$ ed. revista e actualizada, v. II (Fontes. Conteúdo e garantia da relação jurídica), Lisboa: Universidade Católica Portuguesa, 2010, p. 77 ss.; C. da MOTA PINTO, Teoria geral do direito civil, $4 .^{a}{ }^{\text {ed. }}$ por António Pinto Monteiro e Paulo Mota Pinto, Coimbra: Coimbra Editora, 2012 (2. ${ }^{a}$ reimpressão), 
rança»), concentrando-nos mais propriamente nos pactos institutivos (de succedendo), ou seja, nos casos em que, mediante uma convenção, o dante causa constitui alguém como seu herdeiro ou legatário, e que são, afinal, aqueles que verdadeiramente são admitidos no Código Civil, deixando de banda tanto os acordos de successione tertii ${ }^{16}$ - o que acontece quando alguém, com a expectativa de vir a ser chamado, aliena uma futura herança ou um futuro legado de pessoa viva, não havendo, por isso, uma qualquer intervenção do causante da sucessão (o de cuius) - como os factos sucessórios renunciativos (de non succedendo) ${ }^{17}$ - uma vez que, quando alguém renuncia à herança de pessoa viva ou antecipadamente se repudia, poder-se-á concordar que não se opera positivamente sobre a devolução sucessória, não se tratando, por isso, de um verdadeiro acto jurídico designativo ou de uma verdadeira disposição por morte 18

p. 389 ss.; J. de Oliveira ASCEnSÃo, Direito Civil - Teoria Geral, v. II (Acções e factos jurídicos), 2. ${ }^{a}$ ed., Coimbra: Coimbra Editora, 2003, p. 99 ss.; J. de CASTRO MENDES, Direito civil: teoria geral, Lisboa: AAFDL, v. II, 1979 (revisto em 1985), p. 310], urge aqui lembrar, para além dos negócios jurídicos mortis causa (proprio sensu), e seguindo a sistematização de J. de OliveIra ASCENSÃo, Direito Civil Sucessões, cit., p. 39 ss., tanto a existência de negócios jurídicos inter vivos que produzem efeitos depois da morte ( $v . g$., uma dívida que onera a herança e obriga os herdeiros), sendo, por isso, fruto de uma vinculação assumida pelo de cuius e que só afectam os herdeiros na medida em que alteram o objecto da própria herança, como de actos inter vivos destinados a originar efeitos apenas por morte (v.g., as situações previstas nos artigos $962 .^{\circ}, 1231 .^{\circ}$ ss, $1719 .^{\circ}$ e $2029 .^{\circ}$ ).

16 Nos pactos dispositivos, "a pessoa convicta de que sucederá a outra, dispõe, ainda em vida desta, da referida sucessão ou de parte dela a favor de alguém" (I. GALVÃO TElleS, Sucessões: Parte Geral, cit., p. 21).

17 Nesta hipótese, há um "contrato entre autor da sucessão e um seu sucessível, pelo qual este renuncia à sucessão, i.e., antecipadamente a repudia." (neste sentido, I. GALVÃO TELLES, ibidem).

18 Nestes termos, tende a sublinhar-se a dissemelhança entre sucessão pactícia e pacto sucessório, uma vez que, como escreve J. de OlIVEIra ASCENSÃo, Direito Civil - Sucessões, cit., p. 93, "de entre os pactos sobre sucessão de pessoa viva, só os designativos dão origem a uma sucessão fundada num contrato". Aliás, de acordo I. GALVÃO TELLES, Direito das sucessões: noções fundamentais, $6 .^{a} \mathrm{ed}$, Coimbra: Coimbra Editora, 1991, p. 121 ss., orientação que seguimos no texto, apenas estes últimos serão verdadeiros pactos sucessórios, constituindo as outras figuras previstas no artigo 2028. ${ }^{\circ}$ unicamente "actos relativos a sucessões futuras" e que, nos termos da lei, são até inválidos. Com efeito, escreve (a p. 127), "só é acto mortis causa o pacto 
-, conquanto disto não resulte que, do ponto de vista do direito internacional privado, tais situações que excluímos do âmbito da nossa apreciação não mereçam um tratamento conflitual análogo ao que é dado aos pactos de succedendo ${ }^{19}$. Aliás, do mesmo modo, deixaremos fora da nossa análise outros actos ou negócios jurídicos inter vivos com repercussões sucessórias, eventualmente submetidos ainda, pelo menos no plano do direito de conflitos, ao regime da instituição contratual de herdeiro ou da nomeação de legatário ${ }^{20}$.

de succedendo. Só ele é um acto de regulamentação sucessória como o testamento. Só ele visa, como este, marcar o destino post obitum dos bens, instituir herdeiros ou legatários. Só ele é fonte de vocação sucessória”. E, mais adiante, continua (a p. 129): "Os actos mortis causa versam sobre a sucessão própria, que visam regular, designando os seus destinatários; ao passo que aqueles outros actos [os pactos renunciativos e os designativos] versam sobre sucessão alheia."

19 Assim, por exemplo, as regras de conflitos uniformes contidas no Regulamento (UE) $n .^{\circ}$ 650/2012 têm em vista, nos termos do artigo $3 .^{\circ}$, n. ${ }^{\circ} 1$, alínea $b$ ), um conceito amplo de pacto sucessório e que retoma, afinal, em larga medida, a definição constante do artigo $8 .^{\circ}$ da Convenção da Haia de 1 de Agosto de 1989 sobre a lei aplicável às sucessões por morte. Todavia, uma vez que nos pactos de successione tertii não se acha em causa a sucessão de nenhum dos contraentes - efectivamente, o de cuius não intervem no acordo -, também eles não se deverão considerar abrangidos pelo Regulamento. Para mais desenvolvimentos sobre a noção de pacto sucessório acolhida no Regulamento, vide infra, n. 76, in fine.

Por outro lado, e no tangente aos pactos de non sucedendo, mesmo de acordo com as soluções do Código Civil - uma vez que não se trata de uma autêntica disposição por morte, e estando antes em causa a exclusão da vocação sucessória, poder-se-ia apontar à primeira vista para a competência da lex successions -, sempre se tem entendido que a tutela das expectativas do hereditando aconselha a sua equiparação aos pactos de succedendo, sendo por isso de aplicar a alínea c) do artigo $64 .{ }^{\circ}$. Por conseguinte, será a lei pessoal do autor da herança ao tempo da declaração a regular a admissibilidade de tais convenções, bem como as questões de capacidade, representação, falta e vícios da vontade e efeito e medida da renúncia [neste sentido, J. BAPTISTA MACHADO, Lições de Direito Internacional Privado, 3 . $^{\mathrm{a}}$ ed., Coimbra: Almedina, 1985, p. 447 s.; e, aceitando também a aplicação do artigo $64 .^{\circ}$, L. de LIMA PINHeIRo, Direito Internacional Privado [DIP], v. II (Direito de Conflitos. Parte especial), 3. ${ }^{a}$ ed., Coimbra: Almedina, 2009, p. 552].

${ }^{20}$ Referimo-nos às convenções em que as possíveis incidências da sua violação sobre os interesses dos herdeiros e dos credores da herança justificam a sua não submissão integral ao regime geral dos contratos, designadamente às doações inter vivos e às convenções sobre testamento futuro, este último, reconhecido no horizonte do Common Law e igualmente regulado nos direitos dinamarquês e norueguês.

Neste último caso (os will substitutes), o autor, embora não fazendo qualquer instituição (ou nomeação), e conservando, por conseguinte, e em ampla medida, a liberdade de testar, obriga-se a dispor ou a não dispor de certa maneira, havendo 
De resto, tal excurso terá necessariamente um cariz perfunctório, uma vez que, ao avocarmos como desiderato fundamental o estudo do regime internacional privatístico dos pactos sucessórios, circunscrevendo-nos até, mais especificamente, aos problemas suscitados pela determinação da lei aplicável, a explicitação do regime material da sucessão contratual não pode deixar de revestir um valor caracteristicamente ancilar.

4. Aqui chegados, e ainda antes de encetarmos tal tarefa, acrescente-se que o trajecto que propomos radica num determinado pressuposto que importa claramente assumir. Na verdade, e para além de, desde já se dever advertir que o funcionamento do método conflitual poderá conduzir à perturbação das forças de sinergia e de equilíbrio que antes convocámos e que reciprocamente atraem ou apartam o direito da família e o direito das sucessões - uma vez que, ao assentar na técnica do desmembramento ou dépeçage, podemos ser conduzidos na regulação das situações privadas internacionais ao chamamento simultâneo de (eventualmente contraditórias) ordens jurídicas diversas para reger questões que se integram nos dois sectores normativos de que nos ocupamos -, com sério risco para o princípio da harmonia material ou interna e que exprime, nas palavras de FERrer CORREIA, “... a ideia de que no seio do ordenamento jurídico as contradições ou antinomias normativas são intoleráveis"21 -, urge igualmente sublinhar agora, como noutro lado já escrevemos, que não entendemos o direito de conflitos como um sistema fechado e autopoiético, sob pena, aliás, de ele se achar

\footnotetext{
lugar apenas a um direito a indemnização a exercer contra a herança sempre que se verifique uma estipulação mortis causa feita em violação do contract to make a will. Neste caso, efectivamente, a nossa doutrina tem propugnado a sua submissão ao regime conflitual dos pactos sucessórios, e, por isso, ao artigo $64 .^{\circ}$, alínea c) (assim, J. BAPTISTA MACHADO, op. cit., p. 448 ss., e, por analogia, L. DE LIMA PINHEIRO, DIP, v. II, cit., p. 552).
}

${ }^{21}$ Direito Internacional Privado - Alguns problemas, Coimbra: [s.n.], 1985, p. 113. 
destinado a estiolar-se radical e narcisisticamente numa hermética e estéril auto-fundamentação ${ }^{22}$.

Ora, e se isto nos permite apreender o sentido da contemporânea renovação do direito de conflitos - inelutavelmente condenado, ao absorver a emergência de novos valores no âmbito do direito material e ao acomodar-se aos desafios lançados pelos direitos do Homem e pelo ordenamento jurídico da União Europeia, a uma funambular reconstituição das exigências e objectivos que tradicionalmente o predicavam e, por conseguinte, forçado, na busca de novos métodos, a uma exigente ars inveniendi ${ }^{23}$-, também nestas premissas desvelamos a utilidade da análise do direito material relativo à sucessão contratual, uma vez que, como procuraremos elucidar, só através dela as soluções de direito internacional privado vigentes nessa matéria podem ser cabalmente entendidas.

5. No que respeita à sucessão mortis causa, a diversidade dos ordenamentos jurídico-materiais constitui, ainda hoje, uma crua realidade ${ }^{24}$.

22 Para a justificação da convicção que retomamos no texto, veja-se o que dissemos em " "Desenvolvimentos recentes do direito europeu da família e das sucessões" - Algumas notas", Lex Familiae, ano 4, n. 7 (2007), p. 51 s.

${ }^{23}$ Ilustrando o pluralismo de finalidades - e, também por isso mesmo, das formas de regulamentação - do direito internacional privado actual, veja-se H. GAUDEMETTALLON, "Le pluralisme en droit international privé: richesses et faiblesses (Le funambule et l'arc-en-ciel)", Recueil des Cours de l'Académie de Droit International de La Haye [Recueil des Cours], t. 312 (2005), esp. p. 171 ss.

Por outro lado, e como acentua assim, L. GANNAGÉ, Les méthodes du droit international privé à l'épreuve des conflits de cultures, La Haye: Adi-Poche, 2013, face à contemporânea mutação dos interesses, dos valores e dos objectivos - e que acabou desde logo por ditar a insuficiência dos métodos do direito internacional privado existentes para fazer face aos conflitos de culturas -, impõe-se a necessária procura de uma comunidade de métodos (a p. 242 ss.), mas também de valores (a p. 314 ss).

${ }^{24}$ Para além da inúmera literatura onde podem ser colhidas amplas informações de direito comparado relativamente ao direito material das sucessões em geral, vejam-se ainda, especificamente no respeitante à sucessão contratual: Y. H. LELEU, "Les pactes successoraux en droit comparé", Internationale contractuele relaties. De rol van de notaris, Koninklijke Federatie van Belgische Notarissen (ed.), Antwerpen: Maklu, 1995, p. 545 ss.; Les pactes successoraux en droit comparé et en droit interna- 
Na verdade, e para além de casos esporádicos e que, de resto, não relevam no contexto da matéria de que nos ocupamos - pensamos especificamente na Convenção de Washington de 1973 relativa à Lei Uniforme sobre a forma de um testamento internacional (UNIDROIT) -, não são de assinalar particulares trabalhos convencionais de unificação (hoc sensu), uniformização e harmonização do direito material sucessório, nem sequer são expectáveis num futuro próximo, e malgrado o empenho de todos aqueles que vêm sugerindo a sua necessidade e viabilidade, esforços de concertação interestadual determinados a promover a unidade do regime jurídico-material da transmissão mortis causa.

É certo, todavia, que, e apesar das vozes de todos aqueles que se opõem à unificação do direito material das sucessões, importa assinalar a convergência espontânea de muitos ordenamentos jurídicos, mormente europeus, o que corresponde, afinal, à existência de um standard of living comum que determina o nivelamento das aspirações dos cidadãos e que a intervenção das organizações internacionais e a ampla difusão dos instrumentos relativos aos direitos do Homem tem favorecido. Neste sentido, a aproximação do direito da família dos diversos Estados, fruto da sedimentação de um conjunto de princípios comuns relativos à organização pessoal e patrimonial das relações familiares, mormente no respeitante ao casamento e à filiação, tem constituído um importante catalisador da evolução do direito das sucessões. Com efeito, pode até dizer-se que, pelo menos em grande medida, as transformações que este conheceu nas últimas décadas alicerçam-se, mais do que propriamente em razões jus-sucessórias - atinentes, por isso, a uma recompreensão dos institutos jurídicos fundamentais que entretecem o regime da

tional privé: nouveautés en droit français, italien ainsi qu'espagnol et implications pratiques pour la Suisse; actes de la Journée d'Etude de Lausanne du 5 mars 2007, Andrea Bonomi... [et al.], (ed.), Genève: Droz, 2008. 
transmissão patrimonial mortis causa -, nas profundas alterações que a disciplina jurídica da família sofreu na generalidade dos ordenamentos jurídicos ao longo dos últimos decénios, mormente por força do princípio da igualdade entre os sexos, da reivindicação de uma efectiva justiça comutativa no seio da organização patrimonial do casamento, da proibição da discriminação dos filhos nascidos fora do casamento e do alargamento dos efeitos das uniões não matrimoniais, exigências que, verdadeiramente, acabaram por ditar ora o alargamento do leque dos beneficiários da tutela sucessória legítima e/ou legitimária - é conhecida a tendência para nalguns ordenamentos jurídicos ser reconhecida tutela sucessória às uniões de facto e, sobretudo, aos partenariados registados, designadamente, direitos de sucessão legal (legítima ou legitimária), sendo previsível que esta tendência venha a generalizar-se - ora o reforço dos direitos sucessórios daqueles membros da família a quem já antes tinha sido concedida tal protecção ${ }^{25}$. Daí que se imponha até aceitar, com PAMPLONA CORTE-REAL ${ }^{26}$, embora referindo-se especificamente ao direito português, que, e sem que isto permita contrariar a autonomia do direito das sucessões, mesmo do ponto de vista dos princípios constitucionais que o fundamentam ${ }^{27}$, "não fora a repercussão dos tópicos familiares inspiradores da Reforma de 77/78, e o direito sucessório continuaria preso dum imobilismo legislativo que o tem

\footnotetext{
25 Com efeito, foi esse o sentido fundamental das alterações introduzidas no Código Civil em matéria sucessória pelo Decreto-Lei n. ${ }^{\circ}$ 496/77, de 25 de Novembro, e que consistiram fundamentalmente na abolição da discriminação negativa que antes existia, no âmbito da sucessão legítima e legitimária, relativamente aos filhos nascidos fora do casamento e que não houvessem sido legitimados (artigos 2139. ${ }^{\circ}$, n. ${ }^{\circ} 2$, e $2140 .^{\circ}$, n. ${ }^{\circ} 2$, e $2158 .^{\circ},{ }^{\circ} .^{\circ}$ 2) e no reforço da posição sucessória do cônjuge sobrevivo que, até então, não era herdeiro legitimário, aparecia somente em $4 .^{\circ}$ lugar na classe dos sucessíveis (artigo $2133 .^{\circ}$ ), beneficiando apenas, caso a sucessão fosse deferida aos irmãos (ou seus descendentes) do de cuius, de um direito de usufruto vitalício da herança (artigo $2146 .^{\circ}$ ).

${ }^{26}$ Direito da Família..., cit., p. 145.

27 Sobre o elenco e sentido dos princípios de direito constitucional em matéria sucessória, cf., por todos, R. CAPELO DE SOUSA, Lições..., v. I, cit., p. 122 ss.
} 
feito necessariamente distanciar da realidade sócio-económica que lhe subjaz", conclusão que, na verdade, as mais recentes alterações legislativas no âmbito do regime jurídico das sucessões não permitem desmentir ${ }^{28}$.

Sendo assim, podemos então reconhecer que o direito das sucessões de muitos Estados tem conhecido um caminho em muito convergente, sendo de destacar inter alia, e para além da assunção dos novos princípios do direito da família que antes convocámos, o alargamento da protecção do cônjuge supérstite, a generalização do princípio romanista da universalidade - segundo o qual, a transmissão sucessória se deve fazer de modo unitário e independentemente da natureza dos bens que integram a massa hereditária - e o reforço das exigências de solidariedade intrafamiliar, se bem que não se deva omitir a difusão de um pensamento crescente que reclama o alargamento da esfera de autonomia do autor da herança, a impor uma maior liberdade de testar - o que terá efeitos irrecusáveis no âmbito da sucessão legitimária - e a sugerir a remoção dos obstáculos que em muitos sistemas jurídicos continuam a travar o desenvolvimento da sucessão contratual. Acresce ainda que, para além da assumida contratualização do direito das sucessões, a evolução jurídica tem demonstrado a diminuição do recurso aos institutos tipicamente sucessórios (ou familiares, como é o caso do regime de bens do casamento) para estabelecer a organização e transmissão patrimonial no seio da família, ganhando fôlego, afinal, por exemplo, a utilização do trust ou a constituição de sociedades familiares ${ }^{29}$ - neste sentido,

28 Para uma súmula destas alterações, nomeadamente em sede de inventário, cf. R. CAPELO DE SOUSA, "Recentes alterações em Direito da família, Direito dos menores e Direito das sucessões", Boletim da Faculdade de Direito da Universidade de Coimbra [BFDUC], v. LXXXIX, t. I (2013), p. 137 ss.

29 Cf., para a ilustração de tal afirmação, Doing Succession in Europe: Generational Transfers in Familiy Businesses in Comparative Perspective, Isabell Stamm, Peter Breitschmid, Martin Kohli, Zurich... [etc.]: Budrich Unipress... [etc.], 2011. 
a existência das chamadas "sucessões anómalas"30 parece evidenciar um acusado fenómeno de crise do direito das sucessões e que, na sua inércia, se revela incapaz para responder às exigências hodiernas de institucionalização da transmissão patrimonial mortis causa ${ }^{31}$.

Porém, e no que tange especificamente à sucessão contratual, são abissais ainda hoje as divergências que existem entre os diversos ordenamentos jurídicos. Na verdade, se há Estados que rejeitam liminarmente a existência de pactos sucessórios ${ }^{32}$ ou, pelo contrário, os

30 Com mais desenvolvimentos sobre as "sucessões anómalas", aqui se podendo referir tanto as doações inter vivos como os "institutos alternativos ao testamento" (v.g., o trust ou as contas solidárias), vide, por exemplo, F. PADOVINI, "Fenomeno successorio e strumenti di programmazione patrimoniale alternativi al testamento", Rivista del Notariato, 2008, p. 1007 e ss.; e, entre nós, J. DUARTE PINHEIRO, op. cit., p. 193 ss.

31 Sobre esta convocada crise, cf. J. DUARTE PInHEIRo, op. cit., p. 40 ss., e, insistindo também no "imobilismo jus-sucessório", C. PAMPLONA CORTE-REAL, Direito da Família..., cit., p. 121 ss.

32 Era esta a posição tradicionalmente adoptada na Itália (artigo 458. ${ }^{\circ}$, Codice civile), embora o alcance de tal proibição tenha diminuído com a introdução, em 2006, do "patto di famiglia" (artigo 68. ${ }^{\circ}$ bis e ss. do Codice civile). Sobre o "pacto de família" instituído no direito italiano, cf. A. ZOPPINI, "Profili sistematici della successione "anticipata" (note sul patto di famiglia)", Studi in onore di Giorgio Cian, Giovanni De Cristofaro... [et al.] [comitato promotore], Padova: Cedam, 2010, t. II, p. 2547 ss.; E. L. GUASTALLA, "Gli strumenti negoziali di trasmissione della ricchezza familiare: dalla donazione si praemoriar al patto di famiglia", Studi in onore di Giorgio Cian, cit., t. II, p. 1471 ss.; F. DELFINI, "Struttura e patologia del "patto di famiglia”", Studi in onore di Giorgio Cian, cit., t. I, p. 749 ss.; H. DÖRNER/E. FERRANTE, "Der neue italienische "Patto di famiglia", Zeitschrift für Erbrecht und Vermögensnachfolge, v. 15 (2008), p. 53 ss.; G. OPPO, "Patto di famiglia e "diritti della famiglia”", Studi in onore di Nicolò Lipari, Milano: Giuffrè, v. II, 2008, p. 1955 ss.; F. PADOVINI, "Der Familienvertrag ("patto di famiglia")", $Z f R V$, v. 49 (2008), p. 42 ss.; A. DI SAPIO, "Osservazioni sul patto di famiglia (brogliaccio per una lettura disincantata)", Il Diritto di Famiglia e delle Persone, v. XXXVI (2007), p. 289 ss.; F. TASSINARI, "Interdiction des pactes successoraux en droit positif italien et perspectives de réforme", Les pactes successoraux en droit comparé..., cit., p. 65 ss.; e, monograficamente, F. VOLPE, Patto di famiglia, Milano: Giuffrè, 2012.

Aliás, também na Argentina vigorava uma proibição absoluta dos pactos sucessórios, se bem que o novo Codigo Civil y Comercial Unificado de la Nación Argentina, destinado a vigorar a partir de 1 de Agosto de 2015, embora fiel a tal tradição (artigos $1010 .^{\circ}, 1546 .^{\circ}, 2286 .^{\circ}$ e $2449 .^{\circ}$ ), e com o claro intento de promover a continuidade da exploração empresarial - aliás, em termos mais amplos que no patto di famiglia -, veio desviar-se de tal princípio, ao estabelecer no artigo 1010. ${ }^{\circ}$, n. ${ }^{\circ}$ 2, que "Los pactos relativos a una explotación productiva o a participaciones societarias de cualquier tipo, con miras a la conservación de la unidad de la gestión 
empresaria o a la prevención o solución de conflictos, pueden incluir disposiciones referidas a futuros derechos hereditarios y establecer compensaciones en favor de otros legitimarios. Estos pactos son válidos, sean o no parte el futuro causante y su cónyuge, si no afectan la legítima hereditaria, los derechos del cónyuge, ni los derechos de terceros" (sobre o direito argentino, veja-se J. Osvaldo MAFFíA, Tratado de las sucesiones, $3^{\text {a }}$ ed., Buenos Aires: Abeledo-Perrot, 2012, v. I, p. 19 ss.).

Também na Bélgica se ultrapassou a proibição genérica de dispor sobre herança futura consagrada no artigo $7910^{\circ}$ do Code civil e a evolução legislativa tem sido no sentido de permitir a sucessão contratual, malgrado a manutenção da interdição da modificação da ordem legal da sucessão através do regime matrimonial (artigo $1388 .^{\circ}$, n. $^{\circ} 1$, Code civil): assim, a Lei de 22 de Abril de 2003 veio autorizar a qualquer um dos (futuros) cônjuges a renúncia antecipada aos direitos sucessórios relativamente à herança do outro (artigo $1388 .^{\circ}$, n. ${ }^{\circ}$ 2, Code civil), na convenção antenupcial ou no pacto que modifique o regime de bens, se no momento em que ela ocorre existirem filhos de qualquer um deles nascidos, ou adoptados, antes do casamento ou seus descendentes [vide, por exemplo, P. DELNOY, Les libéralités et les successions: précis de droit civil, $3^{\mathrm{e}}$ éd., Bruxelles: Larcier, 2010, p. 194 ss.; IDEM, "Une nouvelle possibilité de priver le conjoint de ses droits successoraux supplétifs et de sa réserve héréditaire 'abstraite'", Revue du Notariat Belge, 2004, p. 226 ss.; F. TAINMONT, "Le droit successoral belge", Electronic Journal of Comparative Law, v. 14.2 (October 2010), p. 1 ss.; IDEM, "La loi du 22 avril 2003 relative aux droits successoraux du conjoint survivant", Revue Trimestrielle de Droit Familial, 2003, p. 735 ss.; M. GRÉGOIRE, "À propos des effets du pacte successoral permis par l'article 1388 C. Civ. Effets de la modification ultérieure du pacte", Liber amicorum Paul Delnoy, Christine Biquet-Mathieu... [et al.] (éd.), Bruxelles: De Boeck \& Larcier, 2005, p. 247 ss.].

Por outro lado, no direito comum espanhol vigora uma proibição genérica de sucessão contratual (artigos $658 .^{\circ}$ e $1271 .^{\circ}, 2$, Código Civil), conquanto tal solução não tenha impedido o desenvolvimento de mecanismos alternativos aos pactos sucessórios e aquela seja afastada nalguns ordenamentos regionais, ora em geral (por exemplo, em Navarra e no País Basco) ora desde que estabelecida em favor dos cônjuges e/ou dos descendentes (é o caso da Catalunha e da Galiza) (vide I. Herrero Alonso, "Le principe de la prohibition des pactes successoraux et les instruments alternatifs du Code civil espagnol", Les pactes successoraux en droit comparé..., cit., p. 99 ss.; M. MARTÍNEZ MARTÍNEZ, "Les pactes successoraux dans les droits régionaux de l'Espagne”, Les pactes successoraux en droit comparé..., cit., p. 107 ss.).

Por fim, na França, não obstante a conhecida proibição dos pactos sucessórios (artigos $722 .^{\circ}$ e $1130 .^{\circ}$, Code civil), e que teve origem na hostilidade revolucionária perante um mecanismo que tinha, no Ancien Régime, como função "manter intacto o património familiar e, com ele, o lustre das casas nobres" (as palavras são de EDUARDO CORREIA, op. cit., p. 71), a Loi n ${ }^{\circ} 2006-728$ du 23 juin 2006 portant réforme des successions et des libéralités introduziu novos e importantes desvios a este princípio, que, na verdade, mesmo antes não era absoluto. Com efeito, já desde 1965, era admitida a "cláusula comercial" contida no pacto nupcial e que permitia ao supérstite manter "les fonds de commerce" ou uma exploração civil ou rural que os cônjuges explorassem em comum e que constituíssem a fonte do seu sustento, podendo por isso o sobrevivo adquirir ou ver ser-lhe atribuído um bem próprio do de cuius (artigo $1390 .^{\circ}$ ss., Code civil); por outro lado, a reforma do direito do 
divórcio, em 1975, estabeleceu a possibilidade de se renunciar por acordo e antecipadamente à sucessão do cônjuge em caso de separação ("séparation de corps") (artigo 301..$^{\circ}$ Code civil); também, desde 1978, se permite a celebração de pactos sobre sucessões futuras tendo em vista o princípio da continuidade das sociedades comerciais (com excepção das sociedades anónimas) pelos herdeiros; de resto, já antes se aceitava, no contexto matrimonial, e tendo em vista compensar a fragilidade da tutela sucessória do cônjuge sobrevivo, a existência de "donations au dernier vivant", sendo por conseguinte autorizada a instituição contratual ou a doação de bens futuros, tanto nas convenções antenupciais como depois da celebração do casamento, feitas pelos cônjuges ou por um terceiro a um dos cônjuges. Seja, como for, através da $L o i \mathrm{n}^{\circ}$ 2006-728, foi alargado significativamente o leque de sucessão pactícia, sendo de referir, por exemplo, a extensão das hipóteses em que são admissíveis as "libéralités-partages" (artigo 1075. ${ }^{\circ}$, ss., Code civil), classicamente apenas admitidas quando feitas pelo de cuius a favor dos seus descendentes (cf., por exemplo, sobre o direito francês, A.-M. LEROYER, Droit des successions, $3^{\mathrm{e}}$ éd., Paris: Dalloz, 2014, p. 226 ss.; F. TERRÉ/Y. LEQUETTE/S. GAUDEMET, Les successions, les libéralités, $4^{\mathrm{e}}$ éd., Paris: Dalloz, 2014, p. 601 ss.; Y. FAVIER, "Le principe de la prohibition des pactes successoraux en droit français", Les pactes successoraux en droit comparé et en droit international privé..., cit., p. 29 ss.; M. PEREÑA VICENTE, "Nuevo marco legal de los pactos sucesorios en el Derecho francés", Revista Crítica de Derecho Inmobiliario $[R C D I]$, n. $^{\circ} 710$ (2008), pp. 2485 ss.).

De qualquer forma, ainda hoje são hostis à admissibilidade dos pactos sucessórios inúmeros Estados, designadamente, todos aqueles que sofreram mais intensamente a influência do Código Napoleónico, directa ou indirectamente (por exemplo, através do direito espanhol ou português), os antigos Estados comunistas (com excepção dos Estados Bálticos e a Hungria), bem como a Suécia [Cap. 17. ${ }^{\circ}$, I, do Código das Sucessões (Ärvdabalken)] e a Finlândia [Lei das Sucessões, 10, 5 (Perintökaari)]. No que diz respeito ao primeiro grupo de casos, resulta tal solução dos artigos $1130 .^{\circ}, 791 .^{\circ}, 1389 .^{\circ}$ e $600 .^{\circ}$ do Código civil luxemburguês, conquanto, todavia, e à semelhança do direito francês, se admita a donation partage e a instituição contratual feita pelos nubentes ou pelos cônjuges; do mesmo modo, não obstante a proibição genérica de pactos sucessórios, são expressamente admitidas as doações mortis causa nos Países Baixos [artigos 4:42, e 4:4, 2, al.b), Burgerlijk Wetboek]; por fim, decorre igualmente do artigo $426 .^{\circ}$ do Código Civil brasileiro tal interdição geral dos pactos de corvina (a norma referida dispõe que "não pode ser objeto de contrato a herança de pessoa viva"), conquanto alguns autores vejam na partilha antecipada dos bens do de cuius realizada inter vivos pelos ascendentes (art. 2.018, Código Civil) um desvio a tal impedimento, embora para muitos um mero adiantamento de legítima, do mesmo modo que alguma doutrina vem aceitando que, na convenção antenupcial, e apesar do artigo $1655 .^{\circ}$ (que dispõe que será nula a convenção ou cláusula aí estipulada que contravenha disposição absoluta de lei), os nubentes possam dispor acerca da recíproca e futura sucessão, desde que não ultrapasse a metade dos bens [para mais desenvolvimentos, cf. PONTES DE MIRANDA, Tratado de direito privado - Parte especial. Direito das sucessões. Sucessão em geral, sucessão legítima, Giselda Hironaka, Paulo Lôbo (act.), São Paulo: Ed. Revista dos Tribunais, 2012, pp. 53 ss, 229 ss.; M. BERENICE DIAS, Manual das Sucessões., $2{ }^{a}$. ed. São Paulo: Revista dos Tribunais, 2011, esp. n. ${ }^{\circ}$ 11.7]. 
admitem em larga medida ${ }^{3}$, noutros, a admissibilidade da instituição contratual de herdeiro apenas é reconhecida no contexto da organização patrimonial do casamento, exigindo-se que tais estipulações sucessórias sejam incluídas nas convenções antenupciais ${ }^{34}$ ou, pelo menos, o que acontece nos ordenamentos jurídicos não vinculados

33 Assim acontece na Alemanha ( $\$ 2274$, ss., BGB) (vide, por exemplo, D. LEIPOLD, Erbrecht: ein Lehrbuch mit Fällen und Kontrollfragen, 20., neubearb. Aufl., Tübingen: Mohr Siebeck, 2014, p. 491 ss.; WOLF-DIETRICH WALKER, Erbrecht, begr. von Hans Brox, 25., vollst. neu bearb. Aufl., München: Vahlen, 2012, p. 85 ss.) e na Suíça (artigo $494 .^{\circ}$, ss., Código Civil) (cf. P.-H. STEINAUER, Le droit des successions, Berne: Stämpfli, 2006, p. 309 ss.; Erbrecht, Peter Breitschmid... [et al.], 2. Aufl., Zürich... [etc.]: Schulthess, 2012, p. 90 ss.) e onde os pactos sucessórios designativos e, desde logo, as doações mortis causa, são em geral admitidos, bem como nalguns sistemas jurídicos que por estes foram amplamente influenciados, como é o caso do direito turco (artigo 485. ${ }^{\circ}$, ss., Código Civil) [cf. N. KESEN, "Besonderer Teil”, Internationales Erbrecht Türkei, Hans-Peter Schömmer, Nebi Kesen, München: Beck, 2004, p. 98 s.].

Todavia, embora reconhecendo ali a influência do $B G B$, os pactos sucessórios não são admitidos, por exemplo, nem na Grécia [artigo 368. ${ }^{\circ}$, Código Civil, embora sejam admitidas as doações mortis causa, conquanto revogáveis, e algumas partilhas em vida; de resto, e de acordo com o Decreto-legislativo 472/1974, a designada, por Gerhard Kegel (G. KEGEL/K. SCHURIG, op. cit., p. 1015), Lei Onassis, sempre que um cidadão grego seja casado com um estrangeiro, este pode renunciar à herança daquele, incluindo a legítima, através de um contrato celebrado no país estrangeiro do domicílio ao tempo de tal renúncia) [vide A. GRAMMATICAKI-AlEXIOU, "The Law of Succession”, Introduction to Greek Law, Konstantinos D. Kerameus... [et al.] (ed.), $3^{\text {rd }}$, rev. ed., Alphen aan den Rijn... [etc.]: Kluwer Law International... [etc.], 2008, p. 206; S. VRELlis, Private International Law in Greece, Alphen aan den Rijn: Kluwer Law Internat., 2011, p. 141 s.] nem em Taiwan, conquanto aqui seja possível a instituição do trust, inter vivos ou mortis causa (Taiwan's Trust Act) [vide WAN WEN-YEU/WANG CHIH-CHENG/SHIEH JER-SHENQ, "Trust Law in Taiwan: History, Current Features and Future Prospects", Trust Law in Asian Civil Law Jurisdictions: a Comparative Analysis, Lusina Ho and Rebecca Lee (ed.), Cambridge: Cambridge Univ. Press, 2013, p. 63 ss.].

Acresce ainda que também no direito dos países do Common Law, embora os pactos sucessórios sejam ignorados, o trust, na sua inultrapassável plasticidade, permite a organização da transmissão mortis causa por força do contrato (cf. J. PERRIN, Le trust à l'épreuve du droit successoral en Suisse, en France et Luxembourg: Étude de droit comparé et de droit international privé, Genève: Droz, 2006, p. 151 ss.). Ao invés, há Estados onde, embora os pactos sucessórios sejam em geral desconhecidos, são admitidos tanto os testamentos irrevogáveis como as doações mortis causa [assim acontece, por exemplo, na Dinamarca (Arveloven)].

34 Como vimos, é esse o caso português e onde, como é sabido, não é permitido aos cônjuges modificar o regime de bens do casamento (artigo $1714 .^{\circ}$ ). 
ao princípio da imutabilidade do regime de bens do casamento, acordadas entre os cônjuges ${ }^{35}$.

6. Especificamente no que diz respeito ao direito português, e ao tratamento que aqui é dado às sucessões não abertas, convem lembrar que o artigo $2028 .^{\circ}$, n. $^{\circ} 2$, dispõe que os contratos sucessórios - seja quando alguém renuncia à sucessão de pessoa viva ou dispõe da sua própria sucessão ou da sucessão de terceiro ainda não aberta - apenas são admitidos nos casos previstos na lei, sendo nulos todos os demais - sem prejuízo, todavia, da possibilidade de, nos termos do artigo $946 .^{\circ}$, n..$^{\circ}$, se converter a doação por morte em disposição testamentária, o que apenas acontecerá se tiverem sido observados os requisitos de forma extrínseca dos testamentos $-{ }^{36}$, não se tendo o legislador apartado significativamente dos

35 Para além dos ordenamentos referidos supra, n. 32, lembre-se, por exemplo, o caso da codificação austríaca, onde só são admitidos os pactos sucessórios desde que realizados entre cônjuges, apenas em seu favor (logo, não pode existir a instituição contratual feita pelos cônjuges em favor dos seus descendentes comuns) e desde que não disponham de mais de $3 / 4$ do seu património [\$ $1249 .^{\circ}$, ss., Allgemeines Bürgerliches Gesetzbuch (para uma exposição do regime legal austríaco, cf. Kurzkommentar zum ABGB: Allgemeines bürgerliches Gesetzbuch, Ehegesetz, Konsumentenschutzgesetz, IPR-Gesetz, Rom I- und Rom II-VO, Helmut Koziol, Peter Bydlinski, Raimund Bollenberger (Hrsg.), 4., überarb. Aufl., Wien: Verl. Österreich, 2014, p. 39 ss.; F. HAUNSCHMIDT, Erbschaft und Testament: Erb- und Testamentsrecht, Verlassenschaftsverfahren, Anfechtung letztwilliger Anordnungen, internationales Erbrecht; [inkl. EU-Erbrechtsverordnung], 4., aktualisierte Aufl., Wien: LexisNexis ARD Orac, 2013, p. 67 s.].

36 Para a exposição das soluções que entre nós vigoram no âmbito da sucessão contratual, vide: J. RODRIGUES BASTOS, Direito da família: segundo o código civil de 1966, v. II, Lisboa: Petrony, 1977, p. 194 ss.; F. PEREIRA COELHO, op. cit., pp. 104 ss., 234 s.; J. DUARTE PINHEIRO, op. cit., p. 183 ss.; C. ARAÚJO Dias, op. cit., p. 212 ss.; I. GAlVÃo Telles, Sucessões: Parte Geral, cit., p. 19 ss.; J. de OlIVEIRA ASCENSÃo, Direito Civil - Sucessões, cit., p. 92 ss.; C. da MOTA PINTO, op. cit., p. 390 ss.; EDUARDO DOS SANTOS, op. cit., p. 557 ss.; L. CARVALHO FERNANDES, Lições..., cit., p. 569 ss.; C. PAMPlONA CORTE-REAL, Curso..., cit., p. 81 s.

Seja como for, não é pacífica a admissibilidade da conversão legal estatuída no artigo $946 .^{\circ}$, n. $^{\circ} 2$ (assim, contestando a razoabilidade de tal solução, I. GALVÃo TELles, Sucessões: Parte Geral, cit., p. 20), dando a norma em causa a inúmeras dificuldades interpretativas (por todos, L. CARVAlHO FERNANDES, Lições..., cit., p. 562 ss.). Por outro lado, e como teremos ocasião de ver mais adiante (infra, n. 73), 


\section{princípios relativos aos contratos de herança futura vigentes à luz do Código de Seabra ${ }^{37}$.}

não é pacífica a caracterização das doações mortis causa como autênticos pactos sucessórios.

37 Efectivamente, a proibição alargada dos pactos sucessórios constava já do Código de Seabra e onde se havia retomado uma hostilidade que, aliás, para além de em consonância com os ventos contrários da Revolução que tinham dado lugar ao Code Napoléon, já vinha do direito anterior, malgrado a circunstância de, na prática, e apesar das Ordenações, ser usual antes da nossa codificação civil oitocentista a existência nas convenções antenupciais de cláusulas sobre o destino post mortem dos bens dos esposados (de modo que, escreve M. J. DE ALMEIDA COsTA, Noções fundamentais de direito civil, $5 .^{a}$ ed. revista e actualizada com a colaboração de António Alberto Vieira Cura, Coimbra: Almedina, 2009, p. 557, [t]ais pactos sucessórios eram largamente admitidos e praticados no direito anterior ao Código Civil de 1867"), de resto, situação que viria a ser expressamente autorizada pela Lei de 17 de Agosto de 1761 quanto aos filhos das casas nobres - afinal, mais uma das rupturas setecentistas do nosso direito das sucessões e a que se refere R. DE FIGUEIREDO MARCOS? [R. DE FIGUEIREDO MARCOS "Rupturas setecentistas no direito sucessório português", O direito das sucessões: do direito romano ao direito actual, António Santos Justo... [et al.], Coimbra: Coimbra Editora, 2006, p. 295 ss.].

Para o estudo da sucessão contratual na vigência do Código Civil de 1867, vide, por exemplo: J. BOTELHO MONIZ, "A sucessão pactícia na lei portuguesa", O Direito, ano $78 .^{\circ}$ (1946), p. 311 ss.; M. DOMINGUES DE ANDRADE, Teoria..., v. II, cit., p. 45 s.; M. Ferreira PIMEnTel, Pactos sucessórios: casos que são admitidos no direito português, [s.1.]: [s.n], 1935 (texto dactilografado); EDUARDO CORREIA, op. cit., p. 81 ss.; EDUARDO DOS SANTOS, op. cit., p. 80 s. Sobre os pactos sucessórios na história do direito português, e onde se descobre, afinal, a intíma interdependência e quase osmose que marca a evolução dos regimes de bens do casamento e da sucessão contratual, vide ainda A. COELHO DA ROCHA, op. cit., p. 577; EDUARDO DOS SANTOS, op. cit., p. 78 ss.; EDUARDO CORREIA, op. cit., p. 80 ss.; e, sobretudo, G. BRAGA DA CRUZ, "Les pactes successoraux dans l'ancien droit portugais", Annales de la Faculté de Droit de Toulouse, v. XI (1963), p. 195 ss.; IDEM, "Os pactos sucessórios na História do direito português", Revista da Faculdade de Direito da Universidade de São Paulo, v. LX (1965), p. 93 ss.

Ora, tal desconfiança relativamente à sucessão contratual perduraria, no século XX, por ocasião da preparação do novo Código Civil. Com efeito, e apesar da ressalva dos pactos contidos em convenções antenupciais, e que constituíram objecto de outra proposta, da autoria de F. PESSOA JORGE ["Doações para casamento. Doações entre casados (Anteprojecto de dois capítulos do futuro Código Civil)", Boletim do Ministério da Justiça [BMJ] 124 (1963), p. 287 ss.], já o artigo $3 .^{\circ}$ do Anteprojecto de I. GALVÃo TELLES continha uma proibição genérica da sucessão contratual [vide "Direito das Sucessões", BMJ 54 (1956), p. 19 ss., e ainda, para a discussão das regras então formuladas, "Actas da Comissão Revisora do Anteprojecto do Direito das Sucessões do futuro Código Civil Português" BMJ 133 (1964), p. 57 ss., esp. pp. 61 s., 79 s., 83 ss.], seguindo, na verdade, as linhas já antes traçadas no sentido do não alargamento dos contratos de herança futura, restringidos, por conseguinte, aos contratos de doação para casamento e com exclusão, por isso, da situação expressamente contemplada no Assento do Supremo Tribunal de Justiça, de 16 de Dezembro 
Neste sentido, pode afirmar-se que o nosso legislador, e de acordo com uma tradição bem arreigada, foi particularmente sensível às razões que fundamentam a proibição em geral dos pactos sucessórios: primeiro, por se entender que o autor da herança deve preservar até ao fim o poder de autonomamente determinar a transmissão mortis causa do seu património; depois, porque só após aberta a sucessão parecem estar reunidas as condições para que com esclarecimento, e até por respeito ao de cuius - e sob pena de um repugnante votum captandae mortis aliena - se possa aceitar, repudiar ou dispor da herança ${ }^{38}$.

Contudo, o Código Civil de 1966 consentiu que tais razões perdessem o seu fulgor em hipóteses contadas, pelo que a proibição dos pacta corvina, enquanto manifestação do princípio segundo o qual não é legítima, fora dos casos expressamente previstos na lei, a celebração em vida do de cuius de quaisquer negócios jurídicos que regulem a sucessão, não é completa ${ }^{39}$. Efectivamente, e num claro favor matrimonii ${ }^{40}$, que depois acaba por contagiar, nas condições

de 1927 (doações mortis causa feitas pelos esposados a terceiros) (cf. "Directrizes do trabalho da Comissão do Código civil e comentários do respectivo Presidente", Direito das sucessões - Trabalhos preparatórios do Código Civil, Lisboa: Centro de Estudos de Direito Civil da Faculdade de Direito da Universidade de Lisboa, 1972, p. 3 ss., esp. p. 12 ss.).

38 Para mais desenvolvimentos sobre os fundamentos da rejeição dos pactos sucessórios, cf., por exemplo: J. DUARTE PINHEIRO, op. cit., p. 183; J. DE OLIVEIRA ASCEnSÃo, Direito Civil - Sucessões, cit., p. 93; I. GALVÃo TElles, Direito das sucessões: noções..., cit., p. 127 s.; L. CARVALHO FERNANDES, Lições..., cit., p. 558 ss.; e ainda, considerando, respectivamente, o direito romano, o Code civil de 1804 e o direito português, EDUARDO CORREIA, op. cit., pp. 70, 74 e $81 \mathrm{~s}$.

39 Neste sentido, J. de OlIVEIRA ASCENSÃo, Direito Civil - Sucessões, cit., p. 94, recorda-nos que o artigo $2170 .^{\circ}$ constitui um afloramento de tal princípio, conquanto, na verdade, não caiba nas hipóteses contempladas no artigo $2028 .^{\circ}$, uma vez que a renúncia ao direito de reduzir liberalidades não implica verdadeiramente uma renúncia à herança.

${ }^{40}$ Assumindo claramente este propósito aquando da formulação do regime excepcional relativamente aos pactos sucessórios contidos nas convenções antenupciais, vide I. GALVÃO TElles, Direito das sucessões: noções..., cit., p. 126 s.; L. CARVAlHO FERNANDES, Lições..., cit., p. 570; do mesmo modo, escreve C. PAMPLONA CORTEREAL, Direito da Família..., cit., p. 153: "Em suma, uma apertada teia de medidas 
que veremos, as nossas regras de conflitos de leis, e não obstante a proibição geral de nas convenções antenupciais serem insertas cláusulas destinadas a organizar a sucessão hereditária dos cônjuges ou de terceiro [vide o artigo $1699 .^{\circ},{ }^{\circ}{ }^{\circ} 1$, alínea a)], o artigo $1700 .^{\circ}$, n. ${ }^{\circ} 1$, alínea $a$ ), expressamente prescreve que as convenções antenupciais poderão conter uma instituição (contratual) de herdeiro ou a nomeação de legatário em favor de qualquer dos esposados, feita pelo outro esposado ou por terceiro ${ }^{41}$, acrescentando ainda o artigo 1701. ${ }^{\circ}$, n. $^{\circ} 1$, que tais disposições não poderão ser unilateralmente revogadas depois da aceitação, não sendo lícito ao doador prejudicar o donatário por actos gratuitos de disposição, salvo nas liberalidades feitas por terceiro, caso em que poderá ocorrer a revogação a todo o tempo por mútuo acordo dos contraentes ${ }^{42}$. Para além disso, e tendo em vista a salvaguarda das expectativas do donatário, a caducidade destes pactos sucessórios apenas ocorrerá em casos contados, designadamente sempre que se verifiquem as circunstâncias previstas no artigo $1760 .^{\circ}$ para as doações para casamento ou caso aquele faleça antes do doador (artigo 1703. ${ }^{\circ}$, n. $\left.^{\circ} 1\right)^{43}$. Com o mesmo propósito, determina-se ainda que, quando a instituição contratual em favor de qualquer dos esposados consista numa quota da herança, esta

\footnotetext{
tutelares da situação patrimonial e sucessória do cônjuge sobrevivo, expressiva, talvez mesmo, de uma "prevalência sucessória" da família conjugal sobre a nuclear (?), que vai inclusive ao ponto de excepcionalmente [...], se inserirem pactos sucessórios inseridos em convenções antenupciais (art. 1700 e ss.)". E, na vigência do Código de Seabra, EDUARDO CORREIA, op. cit., p. 84, igualmente exprimia o pensamento segundo o qual "[a] lei não pode deixar de permitir e até encorajar, as iniciativas particulares que tendam a favorecer e a estimular o matrimónio", permitindo a sucessão contratual, incluindo as doações mortis causa, obviar aos inconvenientes decorrentes ora de uma insegura (pois, revogável) designação testamentária ora do excessivo sacrifício que a doação inter vivos implica para o disponente.

${ }^{41}$ De acordo com o artigo $1700 .^{\circ}$, n. $^{\circ} 1$, alínea $b$ ), qualquer um dos esposados poderá ainda proceder à instituição de herdeiro ou à nomeação de legatário em favor de terceiro.

42 Cf. ainda o artigo $1701 .^{\circ}$, n. $^{\circ}$ s 2 e 3.

43 Solução diversa, por isso, da especificamente consagrada quanto às doações por morte feitas por terceiros (artigo $1703 .^{\circ}, \mathrm{n}^{\circ}{ }^{2}$ ).
} 
deverá ser calculada conferindo-se os bens de que o doador haja disposto gratuitamente depois da doação (artigo 1702. ${ }^{\circ}$, n. ${ }^{\circ} 1$ ), da mesma forma que, nas situações em que o objecto da instituição haja sido a totalidade da herança, o doador apenas poderá dispor gratuitamente (inter vivos ou mortis causa) da sua terça parte, havendo igualmente lugar à conferência dos bens de que se haja disposto gratuitamente depois da doação (artigo 1702..$^{\circ}$ n..$^{\circ}$ 2) $^{44}$.

De resto, note-se ainda que, se a instituição de herdeiro e a nomeação de legatário feitas em favor de terceiro, mas sem que este tenha intervindo como aceitante na outorga da convenção antenupcial, valerão apenas como disposição testamentária e não terão efeitos caso a convenção venha a caducar (artigo $1704 .^{\circ}$ ), pelo contrário, e sempre que tenha ocorrido a referida aceitação por parte do terceiro-beneficiário, será aplicável o regime estatuído nos artigos $1701 .^{\circ}$ e $1702 .^{\circ}$, sem prejuízo, todavia, de a disposição mortis causa se tornar ineficaz por caducidade da convenção ou de ser possível a reserva da faculdade de livremente a revogar (artigo 1705. ${ }^{\circ}$, n. $^{\circ} \mathrm{s}$ 1 e 2) ${ }^{45}$. Seja como for, não é despiciendo que, nestes casos, o beneficiário seja muitas vezes um descendente do ou dos esposados, desvelando-se também por aqui o sentido jusfamiliar da sucessão contratual.

7. Em suma, se o direito português manifesta por tradição uma clara hostilidade à sucessão contratual, esta esvanece-se sempre que

\footnotetext{
${ }^{44}$ De qualquer forma, é lícito ao doador, por ocasião do acto de disposição, renunciar, no todo ou em parte, ao direito de dispor da terça parte da herança (artigo $1702 .^{\circ},{ }^{\circ}{ }^{\circ} 3$ ).

45 Aliás, mesmo quando irrevogáveis, tais liberalidades caducarão, se o donatário falecer antes do doador (artigo $1705 .^{\circ}, \mathrm{n}^{\circ}$ 4), e encontram-se submetidas ao regime geral da revogação das doações por ingratidão do donatário e à redução por inoficiosidade (artigo $1705 .^{\circ}, \mathrm{n}^{\circ}{ }^{3}$ ), do mesmo modo que, sempre que ambos os esposados tenham procedido à referida instituição ou nomeação e conste da convenção antenupcial o seu carácter correspectivo, a invalidade ou revogação de uma das disposições determinará a ineficácia da outra (artigo $1706 .{ }^{\circ}$ ).
} 
as disposições por morte se encontram inseridas numa convenção antenupcial. Efectivamente, a sua vinculatividade é até particularmente notória quando tais estipulações mortis causa tenham sido feitas em favor de um dos esposados, ora pelo outro esposado, ora por terceiro, revelando-se, deste modo, um claro favor ao casamento, sendo a sucessão contratual entre nós, afinal, um instrumento predominantemente destinado a acudir à programação económica da vida matrimonial e a organizar as relações patrimoniais do casamento, desempenhando uma função que concomitantemente é levada a cabo tanto pelo regime patrimonial primário (ou seja, os efeitos económicos do casamento independentes do específico regime de bens que nele vigore) como pelos regimes de bens do casamento (stricto sensu). Aliás, e considerando a ampla autonomia que, no que toca a esta última matéria, é reservada aos nubentes (vide os artigos $1698 .^{\circ}$ e $1699 .^{\circ}$ ), pode até discernir-se no regime jurídico relativo às disposições mortis causa contidas nas convenções antenupciais o firme propósito de assegurar a tutela da autodeterminação da vida patrimonial no contexto das relações de família.

$\mathrm{Na}$ verdade, entre os beneficiários das doações mortis causa feitas por terceiros nem sempre se encontra, pelo menos directamente, um dos cônjuges, uma vez que, como decorre do prescrito no artigo $1703 .{ }^{\circ}$ n. ${ }^{\circ}$, e apesar de o donatário falecer antes do doador, não resultará a caducidade das liberalidades em questão, sempre que sobrevivam a este descendentes legítimos do donatário. Por conseguinte, manter-se-á o dever jurídico de cumprimento de tais estipulações sucessórias, apesar da ocasional e prévia dissolução do casamento por morte do cônjuge em benefício do qual hajam sido feitas. Ainda aqui, todavia, ao reconhecer-se tal direito apenas aos descendentes nascidos do casamento por ocasião do qual haja sido outorgada a convenção antenupcial, se encontra indiciada a existência de uma íntima ligação entre o regime patrimonial do casamento e as soluções legais relativas aos pactos 
sucessórios ${ }^{46}$, podendo até dizer-se que a assunção pelos descendentes da posição jurídica do donatário antes falecido viabiliza a conservação das disposições sucessórias, sem prejuízo para o equilíbrio contratual e a justa ordenação das relações patrimoniais do casamento.

Por outro lado, a circunstância de entre nós os pactos sucessórios constituírem fundamentalmente um instrumento de organização das relações patrimoniais do casamento resulta ainda particularmente evidente na preocupação manifestada em manter a intangibilidade do património que com a sua celebração se teve em vista transmitir, tutelando-se dessa forma as expectativas do ou dos esposados em favor de quem haja sido estabelecida uma instituição ou um legado contratuais. Deste modo, às soluções constantes do artigo 1702.', e que asseguram, afinal, a estabilidade patrimonial dos cônjuges - pense-se, por exemplo, na obrigação de conferência dos bens transmitidos gratuitamente pelo disponente após a doação mortis causa -, encontram-se subjacentes as razões que, na verdade, inspiraram o legislador no momento da consagração do princípio da imutabilidade do regime de bens do casamento (artigo 1714. ${ }^{\circ}$ ). Efectivamente, o referido paralelismo resulta tanto mais evidente quanto o Código Civil sentiu a necessidade de expressamente abraçar no elenco dos desvios ao princípio da imutabilidade os casos em que ocorre a revogação ou caducidade das disposições mortis causa [artigo 1715..$^{\circ}$..$^{\circ} 1$, alínea a)].

\footnotetext{
46 Com efeito, a protecção dos filhos nem sequer constitui um desiderato de que o legislador se alheia quando estabelece os critérios legais relativos aos regimes de bens do casamento. Na verdade, não parece que também esse objectivo não tenha sido ponderado quando se estabeleceu a solução constante do artigo $1720 .^{\circ}$, n $^{\circ}{ }^{1}$, alínea $b$ ) - mesmo considerando que o regime imperativo de separação não supõe aqui a existência de descendentes legítimos daquele que, tendo mais de sessenta anos, contrai matrimónio em segundas núpcias, será sobretudo nesse caso que se evitarão atribuições patrimoniais indevidas em favor de quem se case com alguém que reúna os pressupostos de tal proibição legal -, assim como ele resulta perfeitamente claro quando se estabelece a proibição da celebração do casamento no regime da comunhão geral de bens por quem tenha filhos, ainda que maiores ou emancipados (artigo $1699 .^{\circ}, \mathrm{n}^{\circ} 2$ ).
} 
8. Comprovado assim o íntimo elo que existe no nosso direito material entre a regulamentação dos pactos sucessórios e a organização patrimonial do casamento, urge então dedicarmo-nos às soluções de direito internacional privado que valem neste matéria, procurando expor de uma forma sucinta os critérios de resolução dos conflitos de leis plasmados no Código Civil de 1966 - com efeito, e contrariamente ao que ocorreu no âmbito das relações de família, não foi sentida, por ocasião da Reforma de 1977, a necessidade da sua modificação - e no Regulamento (UE) n. ${ }^{\circ}$ 650/2012 do Parlamento Europeu e do Conselho de 4 de Julho de 2012 relativo à competência, à lei aplicável, ao reconhecimento e execução das decisões, e à aceitação e execução dos atos autênticos em matéria de sucessões e à criação de um Certificado Sucessório Europeu, tentando perscrutar o sentido das mutações, mas também das constâncias, que marcam a recente transformação do regime conflitual das sucessões internacionais e, mais propriamente, explicitar se, e em que medida, o legislador europeu se afastou das preocupações que justificaram no Código Civil de 1966 os particulares critérios conflituais relativos aos pactos sucessórios que mais abaixo adiantaremos.

II - Os pactos sucessórios no direito internacional privado - do Código Civil de 1966 ao Regulamento (UE) n. ${ }^{\circ}$ 650/2012 do Parlamento Europeu e do Conselho, relativo à competência, à lei aplicável, ao reconhecimento e execução das decisões, e à aceitação e execução dos atos autênticos em matéria de sucessões e à criação de um Certificado Sucessório Europeu

9. Ao debruçarmo-nos sobre o regime conflitual dos pactos sucessórios sancionado no Código Civil de 1966 e tendo em vista a explicitação do modo como o regime material português da sucessão contratual se encontra aí cristalinamente espelhado, impõe-se que aludamos às 
orientações que caracterizam o nosso sistema de resolução do concurso de normas no espaço naquilo que diz respeito tanto às sucessões em geral como às matérias que, pelo menos de acordo com o paradigma que inspirou o nosso legislador, delas não podem ser dissociadas.

9.1. Na verdade, e embora distante da tendência que mais tarde se viria a acentuar, também entre nós não se rejeitou o método do "picking-and-choosing", podendo dizer-se, e parafraseando as palavras de WILLIS REESE, embora referindo-se particularmente à situação existente nos Estados Unidos da América, que "[a]midst the chaos and tumult of choice of law there is at least one point on which there seems to be general agreement... [and] [t]his is that choice of the applicable law should frequently depend upon the issue involved" 4 .

Todavia, urge relembrar que o Código Civil perfilhou uma concepção muito ampla do estatuto pessoal, havendo claramente acreditado nos encantos da ideia segundo a qual existe um conjunto unitário e vasto de matérias ou questões - as profundamente ligadas ao indivíduo - que deverão ser submetidas à aplicação de uma lei constante, única e que os sujeitos individuais sintam como sua, de modo a assegurar a constância do seu estatuto individual e relacional no contexto das situações jurídicas transfronteiriças, pressentindo-se aqui tanto a irradiação das exigências da igualdade do direito como sobretudo a convicção de que apenas uma solução unitária poderia acautelar o princípio da harmonia material (ou da harmonia jurídica interna) e prevenir a perturbação das "coerências invisíveis", a que aludia WILHELM WENGLER ${ }^{48}$, e que inarredavelmente entretecem cada um dos ordenamentos jurídicos internos ${ }^{49}$.

47 "Dépeçage: A Common Phenomenon in Choice of Law", Columbia Law Review, v. 73 (1973), p. 58.

48 "The General Principles of International Private Law", Recueil des Cours, t. 104 (1961), p. 399.

49 Para mais desenvolvimentos sobre a noção de estatuto pessoal e o significado da ampla extensão que este viria a receber no nosso direito, veja-se, com mais referências, N. ASCENSÃO SILVA, "Do estatuto pessoal - Unidade e dispersão (Algumas 
Acresce ainda que, se em geral o valor da unidade de regulamentação implicou tanto a preferência por um estatuto pessoal de grande extensão - este abarca, nos termos do artigo 25. ${ }^{\circ}$, "o estado dos indivíduos, a capacidade das pessoas, as relações de família e as sucessões por morte" - como a perpetuação da tradição manciniana de preponderância da lei da nacionalidade (artigo 31. ${ }^{\circ}$, n. $^{\circ}$ 1) - tendencialmente mais estável que a lei do domicílio ou a lei da residência habitual -, também no que concerne especificamente à transmissão mortis causa, tal exigência - que subjaz à concepção da herança como uma universalidade, reinante, aliás, no direito material das sucessões da generalidade dos Estados - se aclara ${ }^{50}$. Neste sentido, compreende-se que, nos termos do artigo $62 .^{\circ}$, toda a sucessão seja regida pela lei nacional do de cuius, incluindo os poderes do administrador da herança e do executor testamentário, rejeitando-se por conseguinte o desmembramento do estatuto sucessório e que ocorreria caso ele fosse feito depender ora do lugar da situação dos bens que integram a massa da herança ora, mais inverosímil, da lei pessoal de cada um dos (presumíveis) herdeiros ou legatários ${ }^{51}$. Deste modo, se ao juízo conflitual feito mediante a

notas a propósito da comemoração dos 35 anos do Código Civil)", Comemorações dos 35 anos do Código Civil e dos 25 anos da Reforma de 1977, v. II (a Parte Geral do Código e a teoria geral do direito civil), Coimbra: Coimbra Editora, 2006, p. 549 ss.

50 Para uma exposição das regras de conflitos relativas à sucessão mortis causa contidas no Código Civil, vide: J. BAPTISTA MACHADO, op. cit., p. 433 ss.; L. de LIMA PINHEIRO, DIP, v. II, cit., p. 545 ss.; F. de AlMEIDA PIRES, Conflitos de leis: comentário aos artigos $14 .^{\circ}$ a $65 .^{\circ}$ do Código Civil, Coimbra: Coimbra Editora, 2009, p. 146 ss.; A. MARQUes Dos SANTOS, "Testamento público", Colectânea de Jurisprudência, 1995, t. 2, p. 5 ss.; IDEM, "Lei aplicável a uma sucessão por morte aberta em Hong Kong", Revista da Faculdade de Direito da Universidade de Lisboa, v. XXXIX (1998), p. 115 ss.; J. GOMES DE ALMEIDA, Direito de conflitos sucessórios: alguns problemas, Coimbra, Almedina, 2012, passim.

${ }^{51}$ Ainda assim, o artigo $17 .^{\circ}$, n. $^{\circ} 3$, derrogando o preceituado no artigo $17 .{ }^{\circ}, \mathrm{n} .^{\circ}$ 2, e dando abrigo à acepção conflitual do princípio da maior proximidade (cf. A. FERRER CORREIA, Lições..., 2000, cit., pp. 357, 359 ss.), o que se consubstancia, no tangente à sucessão nos bens imóveis, na aplicação da lex rei sitae, pode conduzir-nos ao chamamento de leis diferentes. 
referência ao causante da sucessão não é seguramente alheia uma específica ponderação do valor relativo de cada um dos interesses (conflituais) que confluem no fenómeno da transmissão patrimonial mortis causa ${ }^{52}$, há que reconhecer nesta solução o ingente propósito de, por essa via, se assegurar a unidade de regulamentação de toda a sucessão e para que, na verdade, o facto de submetermos à lex successionis um amplo leque de matérias decerto contribui ${ }^{33}$.

9.2. Ainda que continuemos a olhar exclusivamente para as soluções plasmadas no Código Civil - e deixando, por isso, de remissa os ventos contrários que, desde há décadas, foram soprando por força da intensificação dos esforços de unificação do direito internacional privado levados a cabo através das convenções internacionais e, depois, também, pelo desenvolvimento daquilo que é hoje o direito internacional privado da União Europeia -, haverá sempre que consentir que tal desiderato de unidade nem sempre foi conseguido, bastando para o corroborar atender tanto às múltiplas situações em que a lei da nacionalidade acaba por decair - para além da hipótese particular dos apólides, assim acontece nos conflitos de leis pessoais, uma vez que, sempre que os sujeitos das relações familiares em causa não tenham uma nacionalidade comum, a lex patriae acaba por dar lugar, por exemplo, ora à lei da residência habitual comum ora à lei do país com o qual a vida familiar se ache mais estreitamente conexa - como aos casos em que, fruto da alteração da nacionalidade do sujeito a quem a conexão se refere, e ressalvadas as situações particulares em que o estatuto se encontra legalmente petrificado,

\footnotetext{
52 Para uma súmula das exigências que confluem na determinação do estatuto regulador das sucessões, vide, por exemplo: A. FERRER CORREIA, Direito Internacional Privado - Alguns problemas, cit., p. 122 ss.; N. ASCENSÃO SILVA, "O reconhecimento e a eficácia dos testamentos no Direito internacional privado", Boletim do IRIB, n. 349 (2014), p. 163.; e, na doutrina estrangeira, por exemplo, E. CASTELLANOS RUIZ, Unidad vs. Pluralidad legal de la sucesión internacional, Granada: Comares, 2001, p. 70 ss.

53 Sobre o âmbito da lex successionis na vigência do Código Civil, cf., por todos, J. BAPTISTA MACHADO, op. cit., p. 435 ss.
} 
o conflito móvel resultará afinal na competência sucessiva de ordenamentos jurídicos diversos ${ }^{54}$.

Ora, se o primeiro dos fenómenos de pulverização do estatuto pessoal que referimos não adquire naturalmente interesse de relevo no âmbito da sucessão em geral55 - e o mesmo não se poderia já dizer se o nosso legislador tivesse optado pelo sistema do desmembramento ou cisão do tratamento conflitual da sucessão por morte, uma vez que tanto o critério realista como a escolha da lei pessoal dos herdeiros sempre poderiam abicar no chamamento simultâneo de ordenamentos jurídicos diversos e de conteúdo incompatível -, o mesmo já não poderá dizer-se nas hipóteses em que a nacionalidade do de cuius mude após a verificação de um acto voluntário de disposição mortis causa - ocorrendo a vocação sucessória por força de contrato ou de testamento - ou, ainda, de qualquer acto inter vivos, ainda que regido pela lei pessoal, cuja validade e eficácia possam ser constrangidas por aplicação da lei pessoal do autor da herança ao tempo da morte.

Decorre então daquilo que já dissemos que o tratamento conflitual das sucessões não é unitário, pese embora a circunstância de tal matéria ser incluída no âmbito do estatuto pessoal - e como tal regida primariamente pela lex patriae. Com efeito, no âmbito da sucessão voluntária, e para além das razões que ditam a autonomização conflitual de certas dimensões da conduta declarativa (vg., a capacidade, as formalidades externas), urge aceitar que, malgrado a igual presença das exigências de protecção individual do causante e dos seus familiares - o que reforça os méritos da submissão de

\footnotetext{
54 Vide, monograficamente, T. SCHEUERMANN, Statutenwechsel im internationalen Erbrecht, München: Beck, 1969.

55 porém, e no que respeita aos pactos sucessórios, a relevância da lex familiae, como adiante esclareceremos, pode comprometer a aplicação da lex patriae (vide artigo $53 .^{\circ}, n .^{\circ}$ ), embora também neste caso não se abdique da competência de uma lei única.
} 
toda a sucessão a uma lei, a lei pessoal do avante causa -, sempre a existência de um negócio jurídico sucessório, unilateral ou bilateral, haverá de condicionar a escolha da lei competente para reger a sua admissibilidade, validade e efeitos, atribuindo-se relevo ao tempo da sua verificação ${ }^{56}$. De resto, e para além da pertinência das exigências que, no âmbito da sucessão voluntária, ditam a autonomização do "estatuto da disposição" relativamente à lex successionis, a diversificação do regime conflitual - e, portanto, a quebra da unidade da lei aplicável - é tanto mais patente nesta matéria quanto se propende a aceitar que aos pactos sucessórios, e uma vez que não será inteiramente rigoroso dizer que produzem efeitos exclusivamente mortis causa, deverá ser dado um tratamento conflitual diverso do estatuído para os testamentos ${ }^{57}$.

9.3. Para além do valor da coerência material da regulamentação a que acabamos de aludir, interessa igualmente rememorar que o estatuto pessoal constitui um instituto cujo propósito se destina caracteristicamente a propiciar a estabilidade internacional das situações jurídicas individuais, tanto mais que as qualidades que predicam cada um dos indivíduos, e nas palavras de ANTÓNIO FERRER CORREIA $^{58}$, "não devem ser coisas que o seu portador corra o perigo de ver confiscadas numa fronteira, como artigos de contrabando", devendo antes apresentar-se como "algo de permanente, um foro inviolável".

56 Assim, J. BAPTISTA MACHADO, op. cit., p. 438.

57 Com efeito, ao invés do testamento, e continuando a acompanhar J. BAPTISTA MACHADO, op. cit., p. 443, "o pacto sucessório, como instituição contratual que é, entra em vigor, e vincula, como qualquer outro contrato, a partir da sua celebração". Deste modo, e apesar da aparente semelhança entre os pactos sucessórios recíprocos e os testamentos de mão comum, apenas improprio sensu podemos ver nestes últimos "pactos sucessórios sob a forma de testamento" (assim, EDUARDO CORREIA, op. cit., p. 61 s.).

58 “Unidade do estatuto pessoal”, BFDUC, v. XXX (1954), p. 105. 
De qualquer modo, para além deste genérico fundamento do estatuto pessoal, convem ainda considerar que a aspiração da coerência internacional das soluções ganhou entre nós particular alento quando se enfrentou o problema dos conflitos de sistemas de direito internacional privado, bastando para o demonstrar que atendamos às soluções particulares que o legislador perfilhou no âmbito do reenvio e dos direitos adquiridos e onde, pelo reconhecimento do carácter subordinado das normas de conflitos relativamente à "teleologia imanente" de todo o sistema de determinação da lei aplicável59, discernimos o firme desígnio de garantir, ainda que de diferentes maneiras, a referida continuidade internacional das situações regidas pela lei pessoal ${ }^{60}$.

10. Havendo apresentado os contornos do estatuto pessoal tal como ele se encontra erigido no Código Civil de 1966 e as exigências normativas em que este se enucleia - afinal, os valores da igualdade, unidade e estabilidade do status dos indivíduos -, e depois de termos sugerido os termos em que o estatuto pessoal tende, mesmo entre nós, e por razões várias, a conhecer momentos de dispersão, mormente em matéria sucessória, centremo-nos agora na determinação do estatuto regulador dos pactos sucessórios à luz dos critérios ali sancionados ${ }^{61}$.

59 Ora, verdadeiramente, a orientação que referimos - e que, afinal, não é pacífica na nossa doutrina - é a que nos parece em consonância com uma adequada compreensão do sistema jurídico e do papel que cada um dos seus diferentes strati é chamado, no plano metodológico, a cumprir (para mais desenvolvimentos, cf. os elementos citados, supra, n. 3); aliás, parece-nos, aquela compreensão constitui, afinal, uma congruente e lograda concretização da lição metodológica que convocámos.

${ }^{60}$ Para uma explicitação mais demorada sobre o modo como o Código Civil enfrentou o problema dos conflitos de sistemas de direito internacional privado no âmbito do estatuto pessoal, aí se podendo colher as referências bibliográficas pertinentes, vide N. ASCENSÃO SILVA, "Do estatuto pessoal...", cit., p. 601 ss.

61 Sobre o regime conflitual sucessório na vigência do Código de Seabra, vide: L. FERNANDES FALCÃO, Do Direito Internacional Privado - Dissertação Inaugural para o Acto de Conclusões Magnas na Faculdade de Direito da Universidade de Coimbra, 
10.1. Efectivamente, também no âmbito da sucessão contratual não pôde o legislador alhear-se do velho princípio (designadamente, de direito intertemporal) segundo o qual tempus regit actum, impondo-se por isso assegurar, na medida possível, as expectativas na validade e eficácia dos actos sucessórios que não sofram de qualquer vício à luz da lei que lhes é aplicável no momento da sua prática. Destarte, assim se compreende que se haja entendido como necessário, e apesar da competência de princípio da lei pessoal do de cuius no momento da morte para reger todo o fenómeno sucessório, atribuir relevo ao "estatuto da disposição", ou seja, à lei pessoal do autor da herança ao tempo da declaração negocial ${ }^{62}$. Sendo assim, caso existam estipulações mortis causa feitas concomitantemente

Coimbra: Imprensa da Universidade, 1868, p. 341 s.; A. MACHADO VILLELA, Tratado elementar (teórico e prático) de Direito Internacional Privado, v. I (Princípios gerais) Coimbra, Coimbra Editora, Lda., 1921, p. 442 ss.; V. TABORDA FERREIRA, Sistema do Direito Internacional Privado segundo a lei e a jurisprudência, Lisboa: Ática, 1957, p. 127 ss.; e J. ALBERTO DOS REIS, op. cit., p. 92 ss.. Especificamente sobre a sucessão contratual no anterior Código Civil, cf. A. MACHAdo Villela, op. cit., p. 446 ss., que sustentava, uma vez que decorria do artigo $1457 .^{\circ}$ do Código Civil a natureza estritamente testamentária das doações mortis causa, a aplicação do regime dos testamentos, devendo, por conseguinte, ser regidas pela lei nacional do autor da herança.

62 Assim, de acordo com os artigos $63 .^{\circ}, \mathrm{n} .{ }^{\circ} 1$, e $64 .^{\circ}$, comportará ao estatuto da disposição, e não ao "estatuto sucessório primário", determinar a capacidade para fazer, modificar ou revogar uma disposição por morte, bem como as exigências da forma especial das disposições por virtude da idade do disponente, do mesmo modo que a interpretação das respectivas cláusulas e disposições, salvo se houver referência expressa ou implícita a outra lei [o que lembra as construction clauses tão frequentes no âmbito do comércio internacional (sobre o sentido desta ressalva e que seguramente não parece contemplar uma verdadeira escolha de lei, cf. F. de AlmeIDA PIRES, op. cit., p. 150], a falta e vícios da vontade e a admissibilidade de testamentos de mão comum ou de pactos sucessórios, sem prejuízo, quanto a estes, do disposto no artigo $53^{\circ}$.

Acresce ainda que, segundo o artigo $63 .^{\circ}, \mathrm{n} .^{\circ} 2$, e tendo em vista um eventual conflito móvel e os resultados nefastos que poderiam decorrer da estrita relevância do estatuto actual, aquele que, depois de ter feito a disposição, adquirir nova lei pessoal conservará a capacidade necessária para revogar a disposição validamente feita à luz da lei aplicável no momento da sua verificação.

Sobre o regime da sucessão contratual no direito de conflitos do Código Civil, cf.; J. BAPTISTA MACHADO, op. cit., p. 443 ss.; L. DE LIMA PINHEIRO, DIP, v. II, cit., p. 550 ss.; F. DE AlmeidA PIRES, op. cit., p. 148 ss.; J: GOMES DE AlMEIDA, op. cit., p. 150 ss. 
por distintas pessoas, cada uma delas será regida pela lei pessoal do respectivo autor ${ }^{63}$.

Naquilo que diz respeito à determinação das questões que relevam exclusivamente do "estatuto da disposição", diga-se que este incide particularmente sobre a admissibilidade dos pactos sucessórios bem como sobre o reconhecimento do seu efeito vinculativo, traduzido, desde logo, no afastamento da livre revogabilidade das disposições por morte ${ }^{64}$, o mesmo acontecendo com os limites à liberdade de disposição especificamente impostos no âmbito da sucessão contratual (por exemplo, se a lei limitar o montante máximo da quota da herança que pode ser objecto de uma vocação sucessória contratual) ${ }^{65}$.

63 J. BAPTISTA MACHADO, op. cit., p. 444.

${ }^{64}$ Se a irrevogabilidade constitui um elemento característico dos pactos sucessórios, ele não é definitório (como lembrava, EDUARDO CORREIA, op. cit., p. 57 s.): com efeito, nada impede, como acontece à luz do $\S 2293 .^{\circ}$ do $B G B$, que o disponente reserve o direito de revogação (similarmente, posto que no respeitante às disposições por morte a favor de terceiros e com carácter contratual, cf. o artigo $1705 .^{\circ},{ }^{\circ}, 2$, do nosso Código Civil).

65 Quer isto dizer, por isso, que, ao invés, será a lei determinada nos termos do artigo $62 .^{\circ}$ que fixará, desde logo, o âmbito da liberdade de disposição em geral, ou seja, será à luz da lei nacional do de cuius ao tempo da morte que deveremos apreciar os limites decorrentes da existência de uma quota legitimária ou as restrições estabelecidas em função das qualidades pessoais do autor da herança. Deste modo, a eficácia dos pactos sucessórias ficará em grande medida dependente da lex successionis, apenas por ocasião da abertura da sucessão podendo decidir-se a possibilidade do estrito cumprimento e a plena eficácia do convencionado.

Seja como for, e apesar da circunstância de, pelo menos para alguma doutrina, as doações entre cônjuges não estarem no nosso ordenamento jurídico sujeitas a colação (artigo $2104 .{ }^{\circ}$ ss.), ainda assim, nada neutraliza a necessidade de acautelar em termos conflituais os interesses dos donatários, tanto mais que a sucessão contratual poderá consistir na instituição de herdeiro ou na nomeação de legatário, feita por qualquer um dos esposados, em favor de terceiro que seja, afinal, presuntivo herdeiro legitimário do doador. Nestes casos, e como ensina J. BAPTISTA MACHADO (op. cit., p. 437, n. 1), deverá atender-se a um "estatuto sucessório hipotético", uma vez que deverá caber, pelo menos, à lei pessoal do doador ao tempo da doação indicar quais os presuntivos herdeiros sujeitos à colação ou as condições em que esta se presume dispensada.

Paralelamente, se a obrigação do co-herdeiro levar à colação os bens doados ou a fixação do seu valor decorre da lei da sucessão, que determina assim a legítima, a necessidade de redução por inoficiosidade e a ordem da redução das disposições inoficiosas, no caso de uma doação inter vivos que não seja inoficiosa de acordo com 
Por outra banda, se a instituição contratual não for legítima à luz da lei designada nos termos do artigo $63 .^{\circ}$, tem-se defendido que não poderá ocorrer a sua convalidação à luz do "estatuto sucessório primário", conquanto, na verdade, se afigure razoável admitir, atendendo ao disposto no artigo $946 .^{\circ},{ }^{\circ} .^{\circ} 2$, poder ter lugar a conversão do pacto sucessório numa disposição testamentária, sempre que cumpridos os requisitos de validade (substancial e formal) das disposições testamentárias e desde que o autor da herança não haja já disposto do seu património de modo contrário ${ }^{66}$.

10.2. Acresce ainda que o artigo $64 .^{\circ}$, alinea $c$ ), embora submetendo a admissibilidade dos pactos sucessórios ao estatuto da disposição mortis causa, acautela expressamente o disposto no artigo $53 .^{\circ} \mathrm{e}$ onde se regula a questão da substância e efeitos das convenções antenupciais e do regime de bens do casamento (o chamado estatuto patrimonial secundário do casamento). Conquanto se reconheça tanto o carácter pouco "transparente" desta formulação legal ou até se possa questionar o mérito da solução aí sancionada, tudo leva a crer que o legislador pretendeu excluir a questão da admissibilidade dos pactos sucessórios contidos em convenções antenupciais do âmbito de aplicação da lei pessoal do ou dos seus autores ao tempo da declaração, tendo entendido preferível sujeitá-las à lei reguladora do regime patrimonial secundário ${ }^{67}$. Assim, e independemente do prescrito pelo "estatuto da disposição", o pacto sucessório será ad-

um suposto (hipotético) estatuto sucessório - a lei pessoal do doador ao tempo da doação -, não deverá proceder-se à sua redução de acordo com o estatuto definitivo.

Sobre o âmbito do "estatuto da disposição" nos pactos sucessórios, vide J BAPTISTA MACHADO, op. cit., p. 444 s.

66 Neste sentido, J. BAPTISTA MACHADO, op. cit., p. 445 s., que defende a admissibilidade de tal conversão, se o estatuto regulador da sucessão a consentir e conquanto não resultem prejudicadas as exigências que levaram o legislador, nos artigos $63 .^{\circ}$ e $64 .^{\circ}$, a estabelecer a relevância do estatuto da disposição (no mesmo sentido, cf. L. DE LIMA PINHEIRO, DIP, v. II, cit., p. 552).

67 Sustentando tal entendimento, cf. J. BAPTISTA MACHADO, op. cit., p. 444, e L. DE LIMA PINHEIRO, DIP, v. II, cit., p. 551. 
missível (e vinculativo), desde que tal resulte da lei reguladora das relações patrimoniais secundárias do casamento (lei da nacionalidade comum dos nubentes ou, na falta, lei da residência habitual comum ao tempo do casamento, ou, na sua falta, lei do primeiro domicílio conjugal) ${ }^{68}$.

Seguramente, testemunha-se desta maneira, e agora no plano do direito de conflitos, a união entre o direito da família e o direito das sucessões que desde o início temos estado a convocar e tem-se mesmo assinalado nesta solução a presença de um inquestionável favor matrimonii, que, de modo convergente, justifica, no plano do direito material português, o desvio à proibição geral dos pactos sucessórios, sempre que estes sejam inseridos numa convenção antenupcial, e conquanto algum dos esposados seja instituidor/nomeador ou instituído/legatário69.

Ora, ainda que assentando tanto numa interpretação da ressalva feita na parte final do artigo $64 .^{\circ}$, alínea c) alheada de um qualquer

$68 \mathrm{Na}$ verdade, e do mesmo modo que a convalidação poderá ocorrer sempre que esteja em causa um vício formal, nos termos em que mais adiante referiremos (infra, n. 86 e texto correspondente), de iure condendo, poder-se-ia dizer não existirem razões bastantes para rejeitar um pacto sucessório reconhecido pela lei da disposição, ainda que constante de uma convenção antenupcial e inadmissível ou ineficaz à luz da lei designada nos termos do artigo $53 .{ }^{\circ}$, pelo menos, sempre que o instituidor mortis causa não houvesse disposto de outro modo dos bens sobre o qual aquele incide.

Ora, se existem soluções que correm nesse sentido - por exemplo, a Convenção da Haia de 1989 admite, nos termos do artigo $9 .^{\circ}, \mathrm{n} .{ }^{\circ}$ 2, o efeito convalidante da aplicação da lex successionis (por conseguinte, determinada ao tempo da morte), que regerá então tanto os efeitos vinculativos da convenção como a sua extinção, conquanto apenas nos pactos sucessórios em que apenas uma pessoa disponha da sua sucessão -, sempre será compreensível defender que, se o favor matrimonii parece constituir o fundamento da excepção constante do artigo $64 .^{\circ}$, alínea c), o certo é que a ressalva do previsto no artigo $53 .^{\circ}$, ao fazer prevalecer um regime especial sobre um regime geral, se afigura visar prevenir a perturbação do equilíbrio da organização patrimonial do casamento e até das expectativas dos esposados, propósitos que seguramente foram tidos em vista ao estabelecer-se o regime (material e conflitual) dos pactos sucessórios e que, caso fosse admitida tal convalidação, poderiam aparentemente ser prejudicados.

69 Neste sentido, e com menção do referido favor matrimonii, J. BAPTISTA MACHADO, op. cit., p. 444. 
favor negotii - uma vez que se tem sustentado, como vimos, que não deverá ocorrer a convalidação de um pacto sucessório entre esposados contido na convenção antenupcial, se tal não for admitido pela lei aplicável nos termos do artigo $53 .^{\circ}$, ainda que a outra solução fôssemos conduzidos por aplicação da "lei da disposição" - como admitindo até que o legislador se norteou aqui por um indisfarçável favor matrimonii, impõe-se mesmo assim tecer sobre este aspecto algumas considerações complementares.

Por um lado, o favor aqui subjacente não se reconduz a uma qualquer ideia de aplicação da lei mais favorável, não estando em causa, por conseguinte, o interesse material dos esposados na validade das disposições mortis causa contidas nas convenções antenupciais. De facto, só assim não seria se o espírito de tutela da família conjugal tivesse conduzido o legislador por caminhos mais ousados e a lei designada nos termos do artigo $53 .^{\circ}$ se aplicasse alternativamente à lei pessoal do ou dos disponentes. De facto, e em consonância com tal propósito, teria sido até razoável que o Código Civil se tivesse deixado aliciar aqui por uma solução mais permissiva e claramente inspirada pelo favor negotti, o que, isso sim, se consumaria num arrojado favor matrimonii, facilitando-se a validade das disposições sucessórias contidas nas convenções antenupciais. E isto sem que, na verdade, e sobretudo quando apenas um dos esposados institua contratualmente o outro esposado como herdeiro ou o nomeie como legatário ${ }^{70}$, se pudessem opor

${ }^{70} \mathrm{Na}$ verdade, no caso das convenções antenupciais em que ambos os esposados disponham mortis causa do seu património, a aplicação de leis diferentes poderá suscitar problemas acrescidos, atendendo ao nexo de sinalagmaticidade (improprio $s e n s u)$ que provavelmente existirá entre as referidas cláusulas sucessórias, malgrado a sua feição, ainda assim, caracteristicamente gratuita.

Seja como for, a ruptura do nexo de dependência decorrente de uma aplicação distributiva de leis é, afinal, um problema que também em geral se coloca no funcionamento das regras de conflitos relativas aos pactos sucessórios que não constem de convenções antenupciais, mesmo no contexto das soluções plasmadas no nosso Código Civil. E isto, porque, nos casos em que várias pessoas disponham 


\section{nesta matéria razões conflituais de relevo que fundamentassem a}

formulação de um cúmulo de conexões, isto é, a exclusiva aplicação

num mesmo acto, a admissibilidade e efeitos da instituição contratual (ou nomeação de legatário) feita por cada uma delas, ou, pelo menos, a sua admissibilidade, como acontece no Regulamento (UE) n. ${ }^{\circ}$ 650/2012, será apreciada à luz da respectiva lei pessoal ao tempo da conduta declarativa (como veremos mais adiante, o Regulamento não deixou de estabelecer um tratamento conflitual diferenciado consoante o pacto sucessório se refira à sucessão de uma ou de várias pessoas, se bem que, neste último caso, e no tangente à admissibilidade da sucessão contratual, se sancione um sistema de aplicação cumulativa de leis).

Destarte, em qualquer dos casos, e partindo do princípio segundo o qual não nos encontramos dentro da álea que certamente reveste a celebração de tais pactos sucessórios, deverá o desequilíbrio contratual daí decorrente ser sanado pela mobilização dos institutos de direito civil (específicos ou gerais) previstos pelo ordenamento jurídico competente para reger a instituição contratual em causa ou, se assim não for, por recurso à adaptação.

Com efeito, embora partindo da ideia segundo a qual o pacto sucessório em sentido próprio, ou seja, o pacto de succedendo, é, por definição, "um negócio jurídico bilateral, gratuito e mortis causa" (assim, L. CARVALHO FERNANDES, Lições..., cit., p. 556) e considerando o carácter tendencialmente límpido da distinção entre negócios (e contratos) jurídicos gratuitos e onerosos [cf., por exemplo, M. DOMINGUES DE ANDRADE, Teoria..., v. II, cit., p. 54 ss.; L. CARVAlHO FERNANDES, Teoria..., v. II, cit., p. 82 ss.; C. DA MOTA PINTO, op. cit., p. 400 ss.; J. DE CASTRO MENDES, Direito civil..., v. II, cit., p. 315 ss.; P. PAIS DE VASCONCELOS, Teoria geral do direito civil, 6. ${ }^{a}$ ed., Coimbra: Almedina, 2010, p. 447 ss.; M. J. DE ALmeIDA COSTA, Direito das obrigações, 12. ${ }^{a}$ edição revista e actualizada, Coimbra: Almedina, 2013 (reimpressão), p. 367 ss.; L. M. DE MENEZES LEITÃO, op. cit., p. 183 s.; J. ANTUNES VARElA, Das obrigações em geral, 10. ${ }^{a}$ ed., v. I, Coimbra: Almedina, 2015 (reimpressão), p. 404 ss.; I. GALVÃo TELLES, Direito das obrigações, $7 .^{a}$ ed. revista e actualizada, Coimbra: Coimbra Editora, 1997, p. 96 ss.], há desde logo que reconhecer que "[a] gratuidade e a onerosidade não são qualidades impermeáveis, são dois pólos numa série infinitamente graduável, na qual se inserem negócios mais ou menos gratuitos, como a doação modal, e mais ou menos gratuitos, como as vendas por preços baixos, ou mesmo por preços vis" (P. PAIS DE VASCONCELOS, Teoria..., cit., p. 448).

Ora, parece certo que não podemos ver na simultânea (e até recíproca) instituição contratual feita por vários disponentes num mesmo acto um verdadeiro nexo de sinalagmaticidade genética e funcional, característica dos contratos bilaterais [para mais esclarecimentos, e tendo em mente que as distinções contratos bilaterais (ou sinalagmáticos) versus contratos unilaterais e negócios onerosos versus negócios gratuitos não são coincidentes, vide: M. DOMINGUES DE ANDRADE, Teoria..., v. II, cit., p. 43 s.; L. CARVAlHO FERnANDES, Teoria..., v. II, cit., p. 83 s.; C. DA MOTA PINTO, op. cit., p. 388 s.; J. DE CASTRO MENDES, Direito civil..., v. II, cit., p. 320 ss.; P. PAIS DE VASCONCElOS, Teoria..., cit., p. 445 ss.; M. J. DE AlMEIDA COSTA, Direito das obrigações, cit., p. 360 ss.; M. DE MENEZES LEITÃO, op. cit., p. 180 ss.; J. ANTUNES VARELA, Das obrigações em geral, v. I, cit., p. 395 ss.; I. GALVÃO TELLES, Direito das obrigações, cit., p. 95 s.; A. MENEZES CORDEIRO, Direito das obrigações, v, I, Lisboa: AAFDL, 1986, p. 422 ss.; J. DE OlIVEIRA ASCENSÃo, Direito Civil Teoria Geral, v. III (Relações e situações jurídicas), Coimbra: Coimbra Editora, 


\author{
de uma lei comum aos dois esposados, bastando para o comprovar \\ que, na falta de uma professio iuris, tanto na vigência do Código
}

2002, p 313 s.]. Aliás, e independentemente de a própria natureza mortis causa, ainda que recíproca, da instituição contratual feita por vários causantes parecer dificilmente compaginável com tal classificação, se tal nexo de sinalagmaticidade existisse, não se compreenderia até que em geral a lei previsse a caducidade dos pactos sucessórios quando o donatário faleça antes do doador (cf. o artigo $1703 .^{\circ}$, n. ${ }^{\circ} 1$; porém, os artigos $1703 .^{\circ}$, n. $^{\circ} 2$, e $1706 .^{\circ}$ ). Sobre a questão, em geral, cf. D. ROTHE, Erbvertrag und Synallagma, Berlin: Duncker \& Humblot, 2008.

Todavia, não se pode ignorar que, no plano da representação das partes, poderá subjazer a tais situações uma expectativa de correspectividade, conquanto, na verdade, se possa dizer não tratar-se aqui de um único contrato oneroso, muito menos comutativo, mas antes, e apenas, de uma união de contratos (sobre a união, junção ou coligação de contratos, cf: M. J. DE ALMEIDA COSTA, Direito das obrigações, cit., p. 377 ss.; P. PAIS DE VASCONCELOS, Teoria..., cit., p. 540 ss.; IDEM, Contratos atípicos, 2. ${ }^{a}$ ed., Coimbra: Almedina, 2009, esp. p. 218 ss.; M. DE MENEZES LEITÃO, Direito das obrigações, 11. ${ }^{a}$ edição, v. I, Coimbra: Almedina, 2014, p. 190 s.; J. ANTUNES VARELA, Das obrigações em geral, v. I, cit., p. 281 ss.; I. GALVÃO TELLES, Direito das obrigações, cit., p. 87 ss.; A. MENEZES CORDEIRO, op. cit., p. 429 s.; J. DE OLIVEIRA ASCENSÃO, Direito Civil - Teoria Geral, v. III, cit., p. 303 s.), existindo entre eles um nexo de dependência funcional (ou interna) de índole bilateral, conquanto se mantenha a sua "autonomia formal" (vide P. PAIS DE VASCONCELOS, ibidem).

Sendo assim - e não se enquadrando tal hipótese numa estrita alteração superveniente das circunstâncias (artigo $437 .^{\circ}$ ), uma vez que usualmente o facto (vício) que inquina a disposição mortis causa é contemporâneo às estipulações dos contraentes, não se tratando, por conseguinte, da não verificação da pressuposição cuja relevância decorre do artigo $437 .^{\circ}$-, sempre parece que a "vinculação sobrevivente" poderá ser contestada ao abrigo da lei que a regula, caso a outra venha a ser considerada ineficaz (lato sensu) ao abrigo do respectivo estatuto, por mobilização do preceituado para os casos de erro, tendo lugar o funcionamento do regime disposto no artigo $252 .^{\circ}$, designadamente o relativo ao erro sobre a base do negócio [para uma explicação detida das hipóteses tidas em vista pelo erro sobre os motivos (lato sensu) aí regulado, vide, por exemplo, M. DOMINGUES DE ANDRADE, Teoria..., v. II, cit., p. 242 ss.; L. CARVALHO FERNANDES, Teoria..., v. II, cit., p. 217 ss.; C. DA MOTA PINTO, op. cit., p. 512 ss.; J. DE CASTRO MENDES, Direito civil..., v. II, cit., pp. 97 ss., 102 ss.; P. PAIS DE VASCONCELOS, Teoria..., cit., p. 661 ss.; J. DE OliveIRA AsCensão, Direito Civil - Teoria Geral, v. II, cit., p. 147 ss.; e v. III, cit., p. 184 ss.], caso a nossa ordem jurídica seja a competente, ou o de soluções congéneres previstas pela lex causae estrangeira.

De resto, e sempre que (excepcionalmente) não seja possível assegurar o cumprimento do equilíbrio pressuposto pelos contraentes mediante a mobilização do estatuto regulador da "disposição sobrevivente" - ora através do regime do erro, ora através de outros institutos de direito privado intencionalmente destinados a prosseguir, inter alia, a justiça comutativa nas relações contratuais, designadamente, a redução dos negócios jurídicos ou até mesmo o enriquecimento sem causa -, poder-se-á impor uma maior intervenção constitutiva, maxime, correctiva, do decidente, tratando-se, por conseguinte, de um terreno fértil para a mobilização do mecanismo da adaptação. 
Civil (artigo 42..$\left.^{\circ}\right)^{71}$ como de acordo com os critérios decorrentes do Regulamento (CE) 593/2008, do Parlamento Europeu e do Conselho, de 17 de Junho de 2008, sobre a lei aplicável às obrigações contratuais (Roma I) (artigo $4^{\circ} .^{72}$, a determinação da lei aplicável aos

${ }^{71}$ Com efeito, de acordo com o artigo $42 .^{\circ}$, sempre que os contraentes não tenham uma residência habitual comum, será competente a lei da residência habitual da parte que atribui o benefício. Sobre a lei reguladora dos contratos gratuitos à luz do artigo $42 .^{\circ}$, do Código Civil, vide: J. BAPTISTA MACHADO, op. cit., cit., p. 358 ss.; L. DE LIMA PINHEIRO, DIP, v. II, cit., p. 330 ss.

$72 \mathrm{Na}$ falta de escolha de lei, o Regulamento Roma I submete as doações à lei do país em que o contraente que deve efectuar a prestação característica do contrato tem a sua residência habitual (artigo $4 .^{\circ}, \mathrm{n} .^{\circ} 2$ ) - ou seja, do doador -, sem prejuízo de, caso resulte claramente do conjunto das circunstâncias do caso que o contrato apresenta uma conexão manifestamente mais estreita com um outro país, se venha a considerar aplicável a lei desse outro país (artigo $4 .^{\circ}, n .^{\circ} 3$ ). Para a exposição da lei aplicável às doações de acordo com o referido instrumento europeu (ou segundo a Convenção de Roma de 1980), vide, por exemplo, J. CARRASCOSA GONZÁlEZ, "Apuntes sobre la competencia judicial internacional y la ley aplicable a las donaciones: antes y después del Reglamento Roma I", Cuadernos de Derecho Transnacional [CDT], v. 1, n. ${ }^{\circ} 2$ (2009), p. 323 ss.; L. FUMAGALLI, "La Convenzione di Roma e la legge regolatrice delle donazioni", Rivista di Diritto Internazionale Privato e Processuale, v. XXIX (1993), p. 589 ss.; P. JIMÉNEZ BLANCO, "El derecho aplicable a las donaciones", Revista Española de Derecho Internacional, v. XLIX (1997), p. 63 ss.

Ademais, impõe-se considerar que o artigo $1 .^{\circ}, \mathrm{n} .{ }^{\circ} 2$, alíneas $b$ ) e $c$ ), do Regulamento (CE) 593/2008 exclui do seu âmbito de aplicação material as obrigações que decorram de relações de família (ou de relações que a lei que lhes é aplicável considere produzirem efeitos equiparados), incluindo as obrigações de alimentos, bem como as obrigações que resultem dos regimes de bens do casamento (ou de relações que a lei que lhes é aplicável considera produzirem efeitos análogos ao do casamento) e as sucessões. Assim, o regime internacional privatístico das doações para casamento, das doações entre cônjuges e, mais especificamente, das doações mortis causa não se encontra prima facie plasmado no referido instrumento, resultando por isso das regras de conflitos internas ou contidas noutros instrumentos internacionais ou europeus (as designadas "doações residuais").

Todavia, na verdade, nada impede que certo negócio jurídico constitua num determinado ordenamento jurídico um negócio familiar e noutro se encontre submetido ao regime geral dos contratos, acusando-se aqui a emergência de um verdadeiro circulus inextricabilis. Nestes casos, parte significativa da doutrina tem apontado a necessidade de recorrer primeiramente ao direito de conflitos interno, havendo que lançar mão, caso a lex causae assim determinada considerar não estarmos em presença de um negócio familiar, das regras de conflitos do Regulamento, desde que estejamos face a uma doação que gere doações contratuais (para mais desenvolvimentos, e concordando com tal orientação J. CARRASCOSA GONZÁLEZ, "Apuntes...", cit., p. 325). Seja como for, e se parece claro que as doações mortis causa estão claramente excluídas do âmbito de aplicação do Regulamento Roma I, o procedimento que referimos parece-nos discutível - não deixamos de percepcionar aí os indícios de uma criticável modalidade de qualificação -, havendo antes 


\section{contratos gratuitos em geral - e, afinal, as doações mortis causa}

são (ou podem ser) pactos sucessórios ${ }^{73}$-, acaba por se fazer pelo

que mobilizar o pensamento plasmado no artigo $15 .^{\circ}$ do Código Civil, devendo em princípio os concursos de normas e, por conseguinte, os eventuais conflitos de qualificações, ser resolvidos por prevalência dos regimes especiais e, logo, das regras de conflitos que conduzem à designação do ordenamento jurídico em que estes se inserem. E isto, cremos, sem a perturbação do princípio da interpretação autónoma dos conceitos contidos nos instrumentos europeus [vide ainda, A. RODRíGUEz BENOT, "La exclusión de las obligaciones derivadas del Derecho de familia y sucesiones del ámbito material de aplicación del Reglamento Roma I", $C D T$, v. 1, n. ${ }^{\circ} 1$ (2009), p. 112 ss., referindo-se especificamente aos alimentos, aos regimes de bens do casamento e à sucessão].

Para a circunscrição do estatuto sucessório face ao estatuto contratual, designadamente face ao estatuto regulador das liberalidades ou de outros modos de criação ou transferência de bens ou direitos fora da sucessão (por exemplo, os will substitutes) [artigo $1 .^{\circ}$, n. $^{\circ}$ 2, alínea g)], vejam-se: A. BONOMI/P. WAUTELET, Le droit européen des successions: commentaire du Règlement no. 650/2012 du 4 juillet 2012, Bruxelles: Bruylant, 2013, p. 90 ss.; J. CARRASCOSA GONZÁLEZ, El Reglamento Sucesorio Europeo 650/2012 de 4 de julio 2012: análisis crítico, Granada: Comares, 2014, p. 38 ss.

De qualquer modo, atendendo à diversa configuração que as doações mortis causa assumem nos distintos ordenamentos jurídicos, e que já antes convocámos, não é certo que tais doações se encontrem abrangidas pelo Regulamento (UE) n. ${ }^{\circ}$ 650/2012, nomeadamente, quando não constituam, de acordo com a sua lei reguladora, um verdadeiro pacto sucessório. Para mais desenvolvimentos quanto às doações mortis causa, vide A. BONOMI/P. WAUTELET, op. cit., p. 96 ss., que defendem a mobilização do regime das doações entre vivos, logo, a sua exclusão do âmbito do Regulamento (EU) n. ${ }^{\circ}$ 650/2012, sempre que, de acordo com a lei designada nos termos do seu artigo $25 .^{\circ}$, o contrato em causa não seja qualificado como uma verdadeira doação mortis causa ou não se estabeleça aí um regime especial (sucessório) relativamente ao das doações em geral, sendo de rejeitar, por conseguinte, uma inadmissível qualificação lege fori e devendo percorrer-se um iter que é, afinal, e em grande medida, o sugerido pelo artigo $15 .^{\circ}$ do nosso Código Civil (em sentido contrário, excluindo as doações mortis causa do âmbito do Regulamento, vide: J. CARRASCOSA GONZÁlez, El Reglamento..., cit., p. 41). Assim, o regime material português relativo às doações mortis causa apenas será mobilizável sempre que a competência da nossa ordem jurídica seja reconhecida pelo artigo $25 .^{\circ}$ do Regulamento.

Finalmente, e apesar da exclusão enunciada no artigo $1 .^{\circ}$, n. $^{\circ} 2$, alínea $g$ ), sempre a lex successionis relevará quanto a alguns aspectos de tais "transmissões fora da sucessão", designadamente, no concernente à sucessão legitimária e aos mecanismos de protecção dos "herdeiros forçosos" (cf. A. BONOMI/P. WAUTELET, op. cit., p. 93, e, em termos mais gerais, S. LORENZ, op. cit., p. 113 ss).

73 Atendendo desde logo à natureza supostamente híbrida das doações mortis causa (assim, M. DOMINGUES DE ANDRADE, Teoria geral..., v. II, cit., p. 45 s.; e, na vigência do actual direito, também F. PEREIRA COELHO, op. cit., p. 24 s.; C. DA MOTA PINTO, op. cit., p. 392; e L. CARVALHO FERNANDES, Teoria geral..., v. II, cit., p. 81). importa ainda acrescentar que não é pacífica a sua identificação com os 


\section{predomínio do "interesse conflitual" de apenas um dos contraentes}

- designadamente, do doador ou beneficiante -, não se levantando contra esta solução obstáculos de monta.

Por outro lado, e se o favor ao casamento, ainda que apenas conflitualmente prosseguido, parece indesmentível - tendo o legis-

pactos sucessórios, aliás, como resulta já dos apontamentos de direito comparado que fizémos supra, n. 32. De resto, e contribuindo para tal incerteza, a circunstância de o legislador se referir às doações por ocasião da regulamentação dos casos de sucessão contratual parece justificar-se até pela influência que o Código civil francês teve no Código Civil de 1867 e pela hostilidade que aquele demonstrou face a uma designação (pacto sucessório) de sabor aristocrático e intimamente ligada ao direito sucessório do Ancien Régime (aspectos sublinhados por EDUARDO CORREIA, op. cit., p. 81).

Com efeito, se é comum aparecer-nos a afirmação segundo a qual tais doações mortis causa constituem pactos sucessórios (por exemplo, J. BAPTISTA MACHADO, op. cit., p. 445), o problema das relações entre tais tipos contratuais não se apresenta de um modo evidente, tanto mais que o legislador, à semelhança daquilo que acontecia já no Código de Seabra, acabou por deslocar a disciplina da sucessão contratual, ressalvada a sua genérica proscrição contida no artigo $2028 .^{\circ}$, para o âmbito do regime jurídico de cada uma das situações em que ela legalmente pode ter lugar (é o caso das convenções antenupciais). Ora, e malgrado tal sistematização, o que poderia sugerir a distinta natureza das duas figuras, o que é certo é que muitos autores tendem a assumir que tais liberalidades constituem de iure condito autênticos pactos sucessórios (e, com efeito, também nesse sentido poderíamos compreender a remissão contida no artigo $946 .^{\circ}$, n. ${ }^{\circ} 1$, in fine) (por exemplo, L. CARVAlHo Fernandes, Lições..., cit., p. p. 560 ss.; I. GALVÃo TElles, Sucessões: Parte Geral, cit., p. 19; C. PAMPlona CORTE-ReAl, Curso..., cit., p. 79; PAUla BARBOSA, Doações entre cônjuges: enquadramento jus-sucessório, Coimbra: Coimbra Editora, 2008, p. 131 s.), razão pela qual o seu regime internacional-privatístico não é habitualmente diferenciado, se bem que seja incerto se o Regulamento (EU) $n .^{\circ}$ 650/2012 abrangerá, ou não, as doações mortis causa (vide supra, n. 72). Ora, se assim não for, é provável que as regras de conflitos do Código Civil relativas aos pactos sucessórios continuem a aplicar-se a tais doações, mesmo após a entrada em vigor do Regulamento, solução que, na verdade, não nos parece a mais ajustada.

Ao invés, alguma doutrina, embora reconhecendo tratar-se de uma questão cuja resposta depende dos critérios legais sancionados em cada um dos concretos ordenamentos jurídicos e vislumbrando, de qualquer forma, as dificuldades práticas de monta que a sua distinção acarreta, tem sublinhado a diversa natureza das duas figuras, sustentando o entendimento segundo o qual tais liberalidades não serão verdadeiros actos de direito hereditário - mas antes, e apenas, actos entre vivos, uma vez que consideram que o donatário adquire, posto que sub conditione, no momento da doação, podendo dispor dos direitos adquiridos, também condicionalmente -, se bem que estejam conscientes de que alguns dos seus efeitos se acham deveras próximos dos que emergem dos pactos sucessórios (assim, EDUARDO CORREIA, op. cit., p. 61, conquanto a p. 81 , se refira às doações para casamento, "que têm a natureza exacta de pactos sucessórios"). 
lador entendido que urgia acautelar a organização das transmissões mortis causa operada por ocasião da fixação do regime patrimonial do casamento ao abrigo da lei que a regula -, discernimos aqui, e sobretudo, a inclusão no âmbito da lex familiae da regulamentação dos pactos sucessórios contidos em convenções antenupciais, distraindo tal questão do domínio de aplicação da lei que normalmente lhe seria aplicável, ou seja, a lei pessoal do instituidor ou de cada um deles, podendo até aí achar-se a intenção de o nosso legislador resolver afinal um problema específico de qualificação - designadamente a qualificação da questão jurídica da admissibilidade (e efeito vinculativo) das disposições sucessórias contratuais contidas nas convenções antenupciais. Outrossim, e ao reger os pactos sucessórios contidos nestas convenções por esta lei única, privilegiando-se, por conseguinte, uma "solução de integração" 74 - e não descurando que

De outro modo, outros autores, embora vendo em tais doações (as mortis causa) verdadeiros pactos sucessórios, aceitam que nem todas as doações por morte configurarão verdadeiras hipóteses de sucessão contratual - uma vez que a morte poderá não constituir a "causa da devolução dos bens" e tão só uma mera condição (ou até um termo incerto) da atribuição patrimonial -, só assim se compreendendo que o legislador, a par da proibição enunciada no artigo $2028 .^{\circ}$, haja achado necessário proibir expressamente as doações por morte e que não se confundirão, assim, com as doações mortis causa (proprio sensu) (artigo 946. ${ }^{\circ},{ }^{\circ}{ }^{\circ} 1$ ) [neste sentido, vide F. PIRES DE LIMA/J. ANTUNES VAREla, Código civil anotado, v. II, 6 . $^{a}$ ed., Coimbra: Coimbra Editora, 1997, p. 248 s.; e, igualmente ancorado nos diferentes termos em que a morte pode funcionar como causa, condição ou termo, F. PEREIRA COElHo, op. cit., p. 26 s.]. De resto, também o artigo $2170 .^{\circ}$ demonstra afinal que o disposto no artigo $2028 .^{\circ}$ não consome a proibição geral da existência de negócios jurídicos feitos em vida e destinados a regular a sucessão, apenas admitidos nos casos expressamente estabelecidos na lei (assim, J. DE OLIVEIRA ASCENSÃO, Direito Civil - Sucessões, cit., p. 94).

Seja como for, e face à nossa lei, nos casos excepcionais em que as doações que hajam de produzir os seus efeitos por morte do doador são admitidas, estas beneficiam em geral do regime da sucessão contratual, podendo dizer-se serem verdadeiros pactos sucessórios (artigo 1755. ${ }^{\circ}$, n. $^{\circ}$ 2) (F. PIRES DE LIMA/J. ANTUNES VARELA, Código civil anotado, v. IV, 2. ${ }^{a}$ ed., Coimbra: Coimbra Editora, Lda., 1992, v. IV, p. 465 s.).

${ }^{74} \mathrm{Na}$ verdade, e parafraseando H. VALLADÃO ["Développement et intégration du droit international privé, notamment dans les rapports de famille. Cours général de droit international privé", Recueil des Cours, t. 133 (1971), p. 413 ss.], não deixamos de encontrar aqui o eco do princípio segundo o qual a unidade da família exige "un élément de connexion situé audessus des éléments de connexion propres à chacun 
não se admitiu aqui o exercício de qualquer autonomia conflitual, ainda que limitada -, demonstra-se afinal a sobreposição do valor institucional da família e do casamento por oposição à aceitação de um critério de raiz assumidamente individualista e a que, ao sancionar a exclusiva aplicabilidade da lei pessoal do disponente (ou de cada um deles), não deixaria de subjazer uma inegável resignação pulverizadora do regime patrimonial da família.

De qualquer maneira, se parece irrefutável que o Código Civil, ao formular os critérios destinados a dirimir os conflitos de leis relativos aos pactos sucessórios, não se conseguiu desprender do regime material interno - e onde a sucessão pactícia se apresenta primacialmente como um instrumento de programação patrimonial do casamento, sendo a sua admissibilidade recusada fora desse propósito -, embora assumindo que o favor matrimonii é afinal, nada mais, do que um favor legis familiae, também é certo que não se abjurou aqui o princípio da autonomia do direito internacional privado75: verdadeiramente, é a assunção desta exigência que torna compreensível o facto de se ter tido em vista o problema da lei aplicável aos pactos sucessórios celebrados fora das convenções antenupciais, porquanto, no que diz respeito a estas disposições contratuais mortis causa, se aceitou a aplicação da lei pessoal do ou dos causantes.

Ademais, tendo isto em conta, parece até que, mais do que na particular situação em que a lei competente é designada por força

de ses membres" (p. 509), traduzindo-se a referida integração, por oposição à atomização, na "recomposition unitaire, la réunion en une unité de ce qui était séparé en fractions autonomes, souvent minimes et toujours antagonistes" e representando por conseguinte, no contexto de uma visão certamente institucional do casamento, "la synthèse des activités pour le bien commun, la victoire de l'esprit de solidarité, de vraie communauté, altruiste, d'amour, sur l'individualisme, égoïste, expression d'une lutte permanente et agressive".

75 Sobre este princípio, veja-se, por todos, A. FERRER CORREIA, "O princípio da autonomia do Direito internacional privado no sistema jurídico português", Revista de Direito e Economia, v. 12 (1986), p. 3 ss. 
do artigo $53 .^{\circ}$ (instituição contratual de herdeiro e nomeação de legatário contidas nos pactos antenupciais), a especificidade do nosso regime conflitual relativo aos pactos sucessórios se encontra antes na sua geral submissão à lei pessoal do autor da herança ao tempo da declaração, com clara independência, na verdade, relativamente à proibição genérica dos pactos sucessórios contida no nosso direito material.

11. Relativamente à lei aplicável aos pactos sucessórios de acordo com o Regulamento (UE) n. ${ }^{\circ}$ 650/201276, o regime instituído atende desde logo à circunstância de o pacto sucessório se referir apenas

${ }^{76}$ Lembre-se que o legislador europeu adoptou um conceito amplo de pacto sucessório [artigo $3 .^{\circ}, \mathrm{n}^{\circ} 1$, alínea $b$ )], pelo que, na verdade, se submetem às regras de conflitos consagradas no artigo $25 .^{\circ}$ figuras que, ab initio, excluímos do âmbito deste trabalho (por exemplo, os pactos renunciativos ou de non succedendo). $\mathrm{E}$ se, na verdade, muita doutrina sublinha a conveniência de uma interpretação lata da noção de pacto sucessório, aqui abrangendo, inter alia, os testamentos de mão comum, os pactos de tipo germânico, as doações entre cônjuges de bens futuros, as doações-partilha, a renúncia antecipada ao direito de redução por inoficiosidade (é o caso de G. KHAIRAllaH, "La détermination de la loi applicable à la succession", Droit européen des successions internationales: le règlement du 4 juillet 2012, G. Khairallah, M. Revillard (dir.), Paris: Defrénois, 2013, p. 61 s.), outros autores apontam para um sentido mais restritivo, excluindo do seu âmbito, designadamente, as referidas doações entre cônjuges de bens futuros, os testamentos de mão comum, os testamentos-partilha ou a renúncia à acção de redução, sugerindo antes a sua regulamentação de acordo com o artigo $24 .^{\circ}$ (neste sentido, M. REVILlARD, "Portée de la loi applicable", Droit européen des successions internationales..., cit., p. 83).

Especificamente sobre a noção de pacto sucessório aí acolhida, cf., por exemplo: A. BONOMI/P. WAUTElET, op. cit., p. 141 ss.; J. CARRASCOSA GONZÁlez, $E l$ Reglamento..., cit., p. 227; A. DAVİ/A. ZANOBETTI, Il nuovo diritto internazionale privato europeo delle successioni, Torino: Giappichelli, 2014, p. 105 ss.; B. BAREL, "La disciplina dei patti successori", Il diritto internazionale privato europeo delle successioni mortis causa, Pietro Franzina e Antonio Leandro (a cura di), Milano: Giuffrè, 2013, p. 109 ss.

Para desenvolvimentos aprofundados sobre os critérios que, em matéria de sucessão contratual, foram sancionados no Regulamento (UE) n. ${ }^{\circ} 650 / 2012$, vide, para além da bibliografia geral a ele relativa: I. RODRÍGUEZ-URíA SUÁREZ, "La propuesta de reglamento sobre sucesiones y testamentos y su posible aplicación al derecho interrregional: especial consideración de los pactos sucessorios", Anuario Español de Derecho Internacional Privado, v. X (2010), p. 639 ss.; A. FONT Y SEGURA, "La ley aplicable a los pactos sucesorios", InDret: Revista para el Análisis del Derecho, 2/2009, p. 1 ss. 
à sucessão de uma ou de várias pessoas, sancionando-se, por conseguinte, um desmembramento já acolhido na Convenção da Haia sobre a lei aplicável às sucessões mortis causa (artigos 9. ${ }^{\circ}, \mathrm{n} .{ }^{\circ} 1$, e $\left.10 .^{\circ},{ }^{\circ}{ }^{\circ} 1\right)$ e que, na verdade, também vale no Código Civil relativamente aos pactos de succedendo celebrados fora das convenções antenupciais.

11. 1. Assim, de acordo com o artigo $25 .^{\circ}, \mathrm{n}^{\circ} 1$, os pactos sucessórios relativos à sucessão de uma só pessoa são regidos, no que respeita à sua admissibilidade, à sua validade material e aos seus efeitos vinculativos entre as partes, incluindo as condições da sua dissolução, pela lei que seria aplicável à sucessão do disponente se este tivesse falecido no dia em que o pacto foi celebrado, ou seja, e por remissão para o artigo $211^{\circ}$, pela lei do Estado da residência habitual do autor da herança ${ }^{77}$, a não ser que, excepcionalmente, resulte claramente do conjunto da factualidade que, nesse momento, este apresentava uma ligação manifestamente mais estreita com um Estado diferente do da residência habitual 78 .

77 A solução coincide com a sancionada no artigo $9 .^{\circ}, n .^{\circ} 1$, da Convenção da Haia de 1989.

${ }^{78}$ Embora sem que o Regulamento defina aquilo que haverá de ser entendido por residência habitual, o seu Considerando 24 dá-nos uma ideia clara dos termos em que se deverá operar a difícil concretização de tal conceito.

De qualquer forma, é provável que a referida definição venha a constar de uma futura codificação do direito internacional privado europeu, que retomará muito provavelmente a interpretação que tal noção ganhou na jurisprudência do Tribunal de Justiça, ou seja, entendida como o "local onde o interessado fixou, com a vontade de lhe conferir um carácter estável, o centro permanente ou habitual dos seus interesses" [acórdão do Tribunal de Justiça (Terceira Secção), 15 de Setembro de 1994, proc. C-452/93 P, Pedro Magdalena Fernández contra Comissão das Comunidades Europeias (CJTJ, 1994, I-4295 ss., esp. § 22)], tratando-se, por conseguinte, de um conceito com um sentido consolidado no direito internacional privado da União (cf. D. BAETGE, "Auf dem Weg zu einem gemeinsamen europäischen Verständnis des gewöhnlichen Aufenthalts. Ein Beitrag zur Europäisierung des Internationalen Privat- und Verfahrensrechts", Die richtige Ordnung. Festschrift für Jan Kropholler zum 70. Geburtstag, Dietmar Baetge, Jan von Hein und Michael von Hinden (Hrsg.), Tübingen: Mohr Siebeck, 2008, p. 77 ss.). 
Pelo contrário, tratando-se de um pacto sucessório relativo à sucessão de várias pessoas, preferiu-se estabelecer uma conexão múltipla cumulativa, ainda que de cunho limitado, uma vez que a sua admissibilidade depende da concordância de todos os ordenamentos jurídicos que, por força das regras de conflitos gerais, teriam regido a sucessão das pessoas em causa se estas tivessem falecido no dia em que o pacto foi celebrado ${ }^{79}$. Contudo, e a que não é alheio, ainda que abstractamente, um claro favor validitatis ${ }^{80}$, uma vez determinada assim a sua admissibilidade, a validade material, os efeitos vinculativos entre as partes e as condições de dissolução do pacto sucessório serão regidos por uma única lei, designadamente, por aquela, de entre as cumulativamente designadas para apreciar a admissibilidade do pacto, com a qual ele tenha uma ligação mais significativa ${ }^{81}$.

Não obstante, em qualquer destas hipóteses, destaca-se ainda a consagração do princípio da autonomia da vontade ${ }^{82}$, uma vez que, no que respeita a qualquer uma das questões jurídicas a que nos referimos (admissibilidade, validade material, efeitos vinculativos entre as partes e condições de dissolução dos pactos sucessórios), as

79 Posto isto, o legislador europeu acolheu uma solução diversa daquela que vimos vigorar por força do Código Civil, e onde, efectivamente, se sancionou um critério de cariz distributivo.

${ }^{80} \mathrm{E}$ dizemos abstractamente, uma vez que esta solução sempre será menos restritiva do que aquela que resultaria de uma estrita aplicação cumulativa de leis.

81 Contrariamente, nestes casos, o artigo $9 .^{\circ}$ n. ${ }^{\circ} 2$, da Convenção da Haia determina que os efeitos dos pactos sucessórios relativos à sucessão de várias pessoas bem como as circunstâncias que ditam a sua extinção serão submetidos cumulativamente às leis competentes para reger a sua admissibilidade.

Seja como for, e por oposição ao critério de índole distributiva sancionado no nosso Código Civil, tanto a designação de uma lei única, nos termos do Regulamento, como a aplicação cumulativa de leis, segundo a Convenção da Haia, parecem ter a clara vantagem de viabilizar uma regulamentação coerente das disposições contratuais mortis causa feitas por várias pessoas ou, pelo menos, o justo equilíbro da posição jurídica dos vários disponentes.

${ }^{82} \mathrm{~A}$ aceitação do princípio da autonomia consta igualmente do $\operatorname{artigo~} 11 .^{\circ} \mathrm{da}$ Convenção da Haia. 
partes podem escolher a lei que a pessoa ou uma das pessoas cuja herança esteja em causa teria podido eleger nos termos do artigo $22 .^{\circ}$ e nas condições neste previstas ${ }^{83}$.

11.2. Importa ainda referir que, segundo o artigo $26 .^{\circ}$, n. ${ }^{\circ} 1$, se integra na questão da validade material dos pactos sucessórios um leque bastante alargado de matérias, designadamente, a capacidade do autor da disposição por morte para a fazer, as causas concretas que o impedem de dispor a favor de determinadas pessoas ou que proscrevem que uma determinada pessoa possa receber bens da sucessão do autor da disposição, a admissibilidade da representação voluntária, a interpretação da disposição e, por fim, a falta e os vícios da vontade ${ }^{84}$. Para tudo o resto - e também aqui é notória a semelhança com as soluções do nosso Código Civil -, a lex sucessionis, determinada de acordo com os critérios gerais, será a aplicável, cabendo-lhe, desde logo, regular todas as matérias enumeradas no artigo $23 .^{\circ 5}$.

83 Para além de tudo isto, nos termos do artigo $26 .^{\circ}, \mathrm{n} .{ }^{\circ} 2$, do Regulamento, e num claro paralelismo com a solução sancionada no artigo $63 .^{\circ}, \mathrm{n} \cdot{ }^{\circ} 2$, do Código Civil, caso uma pessoa tenha capacidade para fazer uma disposição por morte ao abrigo da lei aplicável nos termos dos artigo $25 .^{\circ}$ (pactos sucessórios), a posterior alteração da lei aplicável não prejudicará a sua capacidade para a alterar ou revogar (sobre esta solução relativa ao conflito móvel, cf. A. BONOMI/P. WAUTELET, op. cit., p. 420 s.; J. CARRASCOSA GONZÁleZ, El Reglamento..., cit., p., p. 233 s.).

${ }^{84}$ Sobre o artigo $26 .^{\circ}$, n. $^{\circ}$ 1, cf.: A. BONOMI/P. WAUTELET, op. cit., p. 415 ss.; e J. CARrascosa GonzÁlez, El Reglamento..., cit., p. 233 ss.

85 Também na Convenção da Haia sobre a lei aplicável às sucessões por morte se sanciona o princípio segundo o qual a validade de um pacto sucessório que se encontre conforme à lei que lhe é aplicável (a lei do tempo da disposição) não poderá ser posta em causa pela lex successionis (artigo $12 .^{\circ}, \mathrm{n} .{ }^{\circ} 1$ ), se bem que tal pacto não possa comprometer nem a legítima de quem não tenha intervindo no pacto nem qualquer outro direito de alguém que dele não possa ser privado pelo de cuius, por força da aplicação do estatuto regulador da sucessão (artigo 12. ${ }^{\circ},{ }^{\circ}{ }^{\circ} 2$ ).

Para uma exposição mais pormenorizada do domínio da lex successionis, tal como ele resulta circunscrito no artigo $23 .^{\circ}, \mathrm{n} .^{\circ} 2$, do Regulamento, vide, por exemplo: M. REVILLARD, op. cit., p. 67 s.; A. BONOMI/P. WAUTELET, op. cit., p. 337 ss.; T. BALlARINO, "Il nuovo regolamento europeo sulle successione", Rivista di Diritto Internazionale, v. XCVI (2013), p. 1124 ss.; J. CARRASCOSA GONZÁlEZ, El Reglamento..., cit., p. 165 ss.; R. MOURA RAMOS, "O Direito internacional privado 
12. Para além dos termos em que o "estatuto da disposição" tende a concorrer com a lex successionis, dando lugar à possível designação de vários ordenamentos jurídicos para regerem os pactos sucessórios, interessa ainda realçar que a questão da forma ganha por força de uma tradição multicentenária um tratamento conflitual autónomo, tendo em vista a assunção de um claro favor negotii, claramente patente a partir do momento que a regra locus regit actum foi perdendo o seu carácter imperativo. Com efeito, a matéria da forma externa das disposições por morte, incluindo a dos pactos sucessórios, beneficia no seio do direito de conflitos de um tratamento particular relativamente àquele que é dado à generalidade da matéria sucessória - designadamente, às questões da substância -, razão pela qual pode ocorrer, desde logo, a convalidação de um facto jurídico que seria inválido face à lei aplicável no momento da sua prática, demonstrando-se deste modo que nem sempre lhe será aplicada a lei da disposição ${ }^{86}$.

Efectivamente, assim acontece no regime estatuído no Código Civil relativamente à forma das disposições mortis causa, bem como à da sua modificação ou revogação, e onde o favor validitatis se consubstancia numa aplicação alternativa de leis (artigo $\left.65 .^{\circ}, \mathrm{n} .^{\circ} 1\right)^{87}$, se bem que, na verdade, procurando solucionar o problema da qualificação das chamadas formalidades ad substantiam, o legislador haja

das sucessões na União Europeia. Primeiras reflexões”, BFDUC, v. LXXXIX, t. I (2013), p. 95.

86 Seja como for, e acompanhando J. BAPTISTA MACHADO, op. cit., p. 451 s., também aqui a solução a adoptar no âmbito dos pactos sucessórios deverá ser diversa da relativa à sucessão testamentária. Com efeito, a mencionada convalidação apenas deverá ter lugar caso o de cuius, a notar a invalidade formal à luz da lei reguladora no momento da celebração do pacto sucessório, não haja aproveitado para dispor através de testamento ou de um outro pacto sucessório, porquanto "seria absurdo considerar o hereditando vinculado por um pacto nulo e não reconhecer por isso validade a uma disposição sua posterior àquele" (J. BAPTISTA MACHADO, op. cit., p. 452).

87 Cf. J. BAPTISTA MACHADO, op. cit., p. 451; L. DE LIMA PINHEIRO, DIP, v. II, cit., p. 235 ss. 
esclarecido que, se a lei pessoal do autor da herança no momento da declaração impuser, sob pena de nulidade ou ineficácia, a observância de determinada forma, ainda que o acto seja praticado no estrangeiro, terá tal exigência de ser respeitada (artigo $\left.65 .^{\circ}, \mathrm{n} .^{\circ} 2\right)^{88}$.

Por outro lado, também nesta matéria o Regulamento (UE) n. ${ }^{\circ}$ 650/2012 ganhou inspiração no favor validitatis, uma vez que a validade formal dos pactos sucessórios depende alternativamente do cumprimento das formalidades extrínsecas previstas pela lex celebrationis, pela lei do Estado da nacionalidade, do domicílio ou da residência habitual de, pelo menos, uma das pessoas cuja sucessão constitua objecto de vocação contratual, quer no momento em que a disposição haja sido feita, quer no momento da morte - para determinar se o disponente tinha ou não o seu domicílio num determinado Estado aplicar-se-á a lei desse Estado (artigo 27. ${ }^{\circ}$ n. ${ }^{\circ} 1$, in fine) -, ou, por fim, caso se trate de um bem imóvel, pela lex rei sitae (artigo 27. ${ }^{\circ}{ }^{89}$. Ainda neste contexto, importa mencionar que,

88 Sobre o sentido desta restrição ao critério da estrita aplicação alternativa de leis, vide: A. FERRER CORREIA, Lições..., cit., 2000, p. 228 ss.; J. BAPTISTA MACHADO, op. cit., p. 450 ss.; e L. DE LIMA PINHEIRO, DIP, v. II, cit., p. 235 s.; F. DE ALMEIDA PIRES, op. cit., p. 151 s. Para mais desenvolvimentos sobre a evolução histórica que conduziu ao carácter subordinado da forma relativamente à substância, podendo entrever-se na solução do artigo $65 .^{\circ}$ que apontamos a confirmação da feição incompleta da autonomia do estatuto da forma, logo, o seu carácter subordinado, A. FERRER CORREIA, Lições de Direito Internacional Privado, Coimbra: Universidade de Coimbra, 1973, p. 330 ss., que, expressamente, se recusa a ver tanto no artigo $36 .^{\circ}, \mathrm{n} .^{\circ} 1$, in fine, como no artigo $65 .^{\circ}$ uma hipótese de conflito de qualificações. Seja como for, e chegados aos conflitos entre a "qualificação forma" e a "qualificação substância", não deixa tal evolução de pesar no sentido da prevalência desta última (assim, A. FERrER CORREIA, Lições..., cit., 2000, p. 228 ss).

89 Acontece ainda que este leque de conexões alternativas é também aplicável às disposições mortis causa que alterem ou revoguem manifestações de vontade já antes predispostas, sendo estas ainda igualmente válidas quanto à forma se respeitarem uma das leis nos termos da qual, de acordo com o n. ${ }^{\circ} 1$ do artigo $27 .^{\circ}$, a disposição por morte que foi alterada ou revogada era válida (artigo $27 .^{\circ}, \mathrm{n} .^{\circ} 2$ ).

Relembre-se, ainda que, e de acordo com o artigo $1 .^{\circ}, \mathrm{n}^{\circ} 2$, alínea $f$ ), do Regulamento, a questão da validade formal das disposições por morte feitas oralmente encontra-se fora do seu âmbito de aplicação material, conservando por isso, neste casos, as regras de conflitos internas relativas à forma dos testamentos pleno interesse. 
ao contrário do critério sancionado no nosso Código Civil, e também aí se desvelando o propósito de conservação dos negócios jurídicos, o artigo 27. ${ }^{\circ}$ n..$^{\circ} 3$, do Regulamento expressamente reconduz ao estatuto da forma todos os preceitos que estabeleçam soluções específicas quanto à forma atendendo à idade, nacionalidade ou outras características pessoais daqueles cuja sucessão seja objecto de um pacto sucessório, o mesmo valendo relativamente às soluções legais que imponham o preenchimento de determinadas qualidades das testemunhas exigidas para a validade de uma qualquer disposição por morte, havendo, por isso, sido retomada a solução acolhida na Convenção da Haia de 5 de Outubro de 1961 sobre a lei aplicável à forma das disposições testamentárias (artigo 5. .).

13. A complexidade dos problemas relativos à determinação da lei aplicável à sucessão mortis causa não decorre apenas da autonomização da questão da forma externa nem sequer do tratamento conflitual diferenciado dos diversos modos de designação sucessória ou dos variados tipos contratuais em que a sucessão pactícia se consubstancia - e isto de modo a atender à específica forma como cada uma dessas vocações se opera e à função de cada uma das modalidades negociais, respeitando as exigências normativas que

Acresce ainda que as regras do Regulamento (UE) n. ${ }^{\circ}$ 650/2012, nos termos do seu artigo $75 .^{\circ}$, não afastam, nos Estados vinculados à Convenção da Haia de 1961 , as soluções aqui sancionadas relativamente à forma dos testamentos e dos testamentos de mão comum. Porém, a Convenção da Haia não abrange os pactos sucessórios, razão pela qual, mesmo nos Estados em que ela vigora, o artigo $27 .^{\circ}$ do Regulamento encontra plena aplicação no âmbito da sucessão contratual (vide, por todos, J. CARRASCOSA GONZÁlez, El Reglamento..., cit., p. 235 ss.). Sobre o $\operatorname{artigo} 27 .^{\circ}$ do Regulamento, cf.: A. BONOMI/P. WAUTELET, op. cit., p. 423 ss.; A. BONOMI/A. ÖZTÜRK, "Das Statut der Verfügung von Todes wegen (Art. $24 \mathrm{ff}$. EuErbVO)", Die Europäische Erbrechtsverordnung..., cit., p. 64 ss.; M. REVILLARD, op. cit., p. 79 s.; B. BAREL, op. cit., p. 133 ss.; C. FISCHER-CZERMAK, "Anwendbares Recht", Europäische Erbrechtsverordnung: (2012/650/EU vom 4. Juli 2012), Martin Schauer und Elisabeth Scheuba (Hrsg.), Wien: Manz, 2012, p. 52 s.; T. BALlarinO, op. cit., p. 1144; R. MOURA RAmos, op. cit., p. 93 ss; A. DAVİ/A. PAGNeTti, op. cit., p. 123 ss. 
em cada uma delas sobressai e que dita a sua individualidade -, uma vez que o próprio modo-de-ser do método conflitual, ao impor o fracionamento da vida privada internacional em numerosas questões jurídicas, não deixa de provocar delicados problemas de delimitação recíproca do âmbito normativo de cada uma das regras de conflitos de leis e até o surgimento de inúmeras e espinhosas antinomias e de que os conflitos de qualificações constituem um acabado exemplo90.

Por conseguinte, a finalizar este breve excurso relativamente aos conflitos de leis no âmbito dos pactos sucessórios, evidencia-se assim a necessidade de aludir, ainda que muito brevemente, ao modo como o chamamento da lei ou das leis reguladoras da sucessão se haverá de compaginar com outros estatutos que, de um modo mais ou menos forte, consoante o tipo de devolução mortis causa em causa, tangenciam a regulamentação do fenómeno sucessório.

$\mathrm{Na}$ verdade, e no contexto da linha argumentativa que seguimos, não devem ser omissas, desde logo, mormente nos casos em que a vocação sucessória radica num título negocial, as relações da lex successionis com, por exemplo, o estatuto regulador da personalidade jurídica e da capacidade (genérica), das obrigações contratuais, das coisas, do regime matrimonial, das sociedades comerciais, dos alimentos ou do trust, o que, na verdade, supõe uma fina cautela na delimitação do âmbito normativo dos conceitos-quadro das normas de conflitos que especificamente assimilam cada uma das matérias que mencionámos ou algum dos aspectos particulares que se aí integram.

Ora, posto que assim seja, nem sempre o funcionamento do referido dépeçage ocorrerá sem embaraços, bastando para o corroborar atender à possibilidade de surgimento de conflitos de qualificações,

${ }^{90}$ Sobre os conflitos de qualificações no contexto do sistema português, veja-se, por todos, A. FERrer CORREIA, Lições..., 2000, cit., p. 225 ss. 
que, desde há muito, a nossa doutrina tem identificado, designadamente, entre a "qualificação pessoal" e a "qualificação real", entre a "qualificação forma" e a "qualificação substância" ou entre a "qualificação regime matrimonial" e a "qualificação sucessória", procurando sanar as contradições que daí emergem.

Seja como for, e sendo impossível aqui, tanto assumir o encargo de tal tarefa interpretativa, como nos demorarmos nos critérios de resolução dos referidos conflitos de qualificações e nos expedientes metodológicos do direito internacional privado - como é o caso da adaptação - que propiciam a boa coordenação dos estatutos e a erradicação das incoerências eventualmente resultantes do chamamento de leis diversas para reger tais relações jurídicas vizinhas, haverá sempre que assentir que o estatuto sucessório poderá sofrer constrições importantes. E é bastante para o esclarecermos lembrar as inúmeras hipóteses em que, na vigência do nosso Código Civil, e por força do estatuto regulador das coisas, a aplicação da lex successionis é coarctada91.

De resto, e malgrado a aparente clarividência da forma como o artigo $1 .^{\circ}$, n. ${ }^{\circ} 2$, do Regulamento (UE) n. ${ }^{\circ}$ 650/2012 demarca negati-

91 Com efeito, já antes vimos que, em nome da acepção conflitual do princípio da maior proximidade, e nos termos do artigo $17 .^{\circ}, \mathrm{n} .{ }^{\circ} 3$, a lex successionis poderá ser a lex rei sitae (supra, n. 51).

Ora, ainda que assim não seja, existem inúmeros casos em que o estatuto real condiciona a aplicação da lei da sucessão. Na verdade, embora caiba a esta estabelecer o elenco dos direitos transmissíveis mortis causa, a partilha, a admissibilidade e regime do fideicomisso, o dever de colação ou a redução por inoficiosidade, será de acordo com o estatuto das coisas que se regerá um leque importante de questões intimamente ligadas à organização dominial. Assim, por exemplo, este determinará, para além do elenco dos direitos reais admissíveis, a sua transmissibilidade mortis causa, a duração da indivisão sucessória, a existência de um direito de pedir a partilha, a licitude das convenções de manutenção de indivisão, as proibições que tenham em vista prevenir o parcelamento fundiário ou a eficácia de uma substituição fideicomissária (neste sentido, J. BAPTISTA MACHADO, op. cit., pp. 436, 437, 442; e, no que respeita à partilha, ainda, L. DE LIMA PINHEIRO, DIP, v. II, cit., p. 550). Paralelamente, e no âmbito da colação e da inoficiosidade, haverá que rejeitar a conferência ou a redução in natura sempre que a lex rei sitae se lhe oponha (J. BAPTISTA MACHADO, op. cit., p. 437, n. 1). 
vamente o seu âmbito de aplicação ratione materiae, as orientações que encontramos aí tanto a propósito do regime matrimonial como do regime dos direitos reais - matérias que o artigo $1 .^{\circ}, \mathrm{n} .^{\circ} 2$, alíneas d) $e k$ ), expressamente arredam - constituem afinal um exemplo demonstrativo daquilo que temos estado a afirmar.

Com efeito, e se quanto ao primeiro dos casos o legislador europeu, para além de excluir do âmbito de aplicação do Regulamento todas as questões relacionadas com o regime de bens do casamento, incluindo as convenções antenupciais, "na medida em que tais convenções não tratem de matérias sucessórias", apenas sentiu a necessidade de esclarecer que "[a]s autoridades que tratem de determinada sucessão [...] deverão, no entanto, em função da situação, ter em conta a liquidação de um eventual regime de bens no casamento ou regime de bens semelhante do falecido ao determinarem a herança do falecido e as quotas-partes dos beneficiários"92, ao invés, no que respeita aos direitos reais foi-se mais longe, aceitando-se expressamente afinal a força cerceadora da lex rei sitae que antes referimos e que assume, na verdade, em termos que não podem aqui se explicitados, uma amplitude diversa daquela que the foi sendo atribuída, ao abrigo do Código Civil, pela nossa doutrina.

92 Considerando 12. E, sobre o significado da exclusão contida no artigo $1 .^{\circ}$, n. $^{\circ}$ 2, alinea $d$ ), do Regulamento, e versando os problemas de delimitação e qualificação aqui implicados, cf. A. BONOMI/P. WAUTELET, op. cit., p. 82 ss.; J. CARRASCOSA GONZÁLEZ, El Reglamento Sucesorio..., cit., p. 40; G. BIAGIONI, "L'ambito di applicazione del regolamento sulle successioni", Il diritto internazionale privato europeo..., cit., p. 49 ss.; H. DÖRNER, "Die Abgrenzung des Erbstatus vom Güterstatut", Die Europäische Erbrechtsverordnung..., cit., p. 73 ss. Em termos gerais, vide ainda, para além das referências contidas na p. 14, a propósito da interdependência entre o regime matrimonial e sucessório e dos direitos dos privados reconhecidos ao cônjuge supérstite, W. MÜLLER-FREIENFELS, "Zur kollisionsrechtlichen Abgrenzung von Ehegüterrecht und Erbrecht", Vorschläge und Gutachten zur Reform des deutschen internationalen Erbrechts, Wolfgang Lauterbach (Hrsg.), Tübingen/Berlin: J. C. B. Mohr (Paul Siebeck)/Walter de Gruyter \& Co., 1969, p. 42 ss.; P. NEY, Das Spannungsverbältnis zwischen dem Güter- und dem Erbstatut, Frankfurt am Main: Peter Lang, 1993. 


\section{III - Conclusão - O sentido de uma evolução:}

14. Aqui chegados, e pensando nas não despiciendas alterações acarretadas pelo Regulamento (UE) n. ${ }^{\circ}$ 650/2012 e nos laboriosos esforços e severos escolhos interpretativos que a sua mise en ouvre não deixará de albergar, poderíamos ser tentados a retornar aos cuidados de BERNARDO SOARES, o ajudante de guarda-livros da cidade de Lisboa, e sempre frisando que a evolução no mundo da praxis e, também por isso, do sistema jurídico, não se faz pela mera sobreposição de tabulae rasae 93 : "A historia nega as coisas certas. Ha periodos de ordem em que tudo é vil e periodos de desordem em que tudo é alto. As decadencias são ferteis em virilidade mental; as epochas de força em fraqueza do espirito. Tudo se mixtura e se cruza, e não ha verdade senão no suppol-la./Tantos nobres ideaes cahidos entre o estrume, tantas ansias verdadeiras extraviadas entre o enxurro!"94.

Ao invés, para além da manutenção dos velhos e intrincados problemas ligados à delimitação e coordenação dos estatutos e até do facto de as novas soluções legais, mais ou menos inovadoras, serem afinal a consagração de velhas ideias e até o decalque de muitas das orientações já concretizadas na Convenção da Haia sobre a lei aplicável às sucessões por morte, podemos ainda assim discernir fortes linhas de continuidade no regime internacional privatístico das sucessões e mais particularmente dos pactos sucessórios, sendo de imediato de destacar a conservação do princípio da unidade da sucessão e a determinação da lex successionis atendendo a elementos de conexão de índole pessoal relativos ao causante da transmissão mortis causa (a residência habitual e a vontade).

93 Para o cabal esclarecimento do modo como o desenvolvimento do sistema jurídico se opera por uma "reconstituição regressiva a posteriori", vide: A. CASTANHEIRA Neves, Curso..., cit., esp. pp. 210 s., 328 ss.; F. PINTO BRONZE, op. cit., p. 678 ss.

94 FERNANDO PESSOA, Livro do desassossego, prefácio e organização de Jacinto do Prado Coelho, 2. ${ }^{a}$ ed. v. II, Lisboa: Ática, 1997, p. 155, 410. 
Com efeito, e para além destes vectores de permanência que em geral se manifestam, é de sublinhar, agora no âmbito da sucessão voluntária, a subsistência do espírito que em muito incitou o legislador civil português de 1966, designadamente, o intento de preservação, no âmbito da vida transfronteiriça, da validade e eficácia dos negócios jurídicos, o objectivo de tutela das expectativas das partes e, por conseguinte, a assunção do desígnio de tentar fazer cumprir o mais possível a vontade do de cuius. Efectivamente, é disto que se trata quando nos deparamos com as soluções relativas às formalidades extrínsecas fundamentalmente construídas tendo em vista o favor validitatis, sendo igualmente tais desiderata que permitem compreender a autonomização de uma lei da disposição por contraposição à lex successionis.

15. Todavia, são muitas as diferenças que em matéria de sucessão contratual apartam o Regulamento (UE) n. ${ }^{\circ}$ 650/2012 do Código Civil, sendo de assinalar, desde logo, tanto a geral substituição da lex patriae pela lei da residência habitual como, sobretudo, a consagração da possibilidade da electio iuris e que, na verdade, acaba por não comprometer a raiz personalista do sistema da lei aplicável às sucessões, uma vez que a escolha da lei apenas poderá recair sobre a lei da nacionalidade ${ }^{95}$.

Em termos mais particulares, refira-se ainda o alargamento do estatuto da forma imposto pelo artigo $27^{\circ}$, n. ${ }^{\circ} 3$, a que já aludimos, bem como o diferente critério adoptado quanto aos pactos sucessórios que incluam disposições relativamente à sucessão de várias

95 Pelo contrário, embora sem que isso possa implicar o afastamento das normas imperativas do ordenamento jurídico competente para reger a sucessão, determinado, ora pela escolha da lei da nacionalidade ou da residência habitual, ora pelo funcionamento dos critérios supletivos, o artigo $6 .^{\circ}$ da Convenção da Haia sobre a lei aplicável às sucessões mortis causa admite ainda a escolha da lex rei sitae, permitindo, por isso, e apesar da sua fidelidade de princípio a um tratamento unitário da sucessão, o seu fracionamento. 
pessoas. Com efeito, ao contrário do critério distributivo resultante da aplicação das disposições do Código Civil, a sua admissibilidade é feita depender da aplicação cumulativa das leis de todos aqueles que no referido contrato disponham mortis causa, se bem que, no que tange à sua validade material e aos efeitos vinculativos entre as partes, incluindo os requisitos da sua dissolução, se haja optado pela aplicação de uma lei única - o que decerto poderá atender de melhor forma às relações de dependência que entrelaçam as atribuições patrimoniais mortis causa feitas simultaneamente pelos vários estipulantes -, conquanto, na verdade, a flexibilidade do critério sancionado - afinal, e uma vez verificada a admissibilidade do pacto relativo à sucessão de várias pessoas por aplicação cumulativa de todas as leis que regeriam a sucessão dos vários disponentes, a proper law do contrato será apenas uma dessas leis, designadamente aquela que tenha com o caso a conexão mais estreita - se encontre longe da rigidez que caracteriza, no Código Civil, os elementos de conexão no âmbito do estatuto patrimonial secundário e das sucessões. Por fim, e por razões a que ainda voltaremos, as regras europeias desconhecem o favor matrimonii que preside, nos termos que vimos, às regras de conflitos relativas aos pactos sucessórios contidas no Código Civil português, não havendo lugar por isso no novo regime, e no respeitante às disposições mortis causa contidas nas convenções antenupciais, à mobilização da lei que as rege.

16. A jeito de conclusão, evidencia-se agora a necessidade de, ainda que sinteticamente, ponderar os termos em que os valores da unidade de regulamentação e de estabilidade internacional que começámos por convocar perpassam ainda o regime europeu conflitual dos pactos sucessórios.

16.1. Primo conspectu, e no que diz respeito ao valor da coerência material das soluções, poderíamos ser desde logo tentados a pensar que os tempos que vivemos são propícios à desarticulação 
dos sistemas e à dispersão, e mesmo dissolução, do estatuto pessoal. Realmente, a mera verificação da tendência de especialização das soluções de direito internacional privado, em muito decorrente do progresso dos esforços convencionais ${ }^{96}$, bem como o carácter francamente evolutivo e ainda fragmentário que caracteriza o direito de conflitos nascido no seio da União Europeia permitem até confortar tal suposição, posto que não esteja longe do espírito de muitos, als Beruf unserer Zeit, a elaboração de um código de direito internacional privado europeu ou, pelo menos, a adopção de um Regulamento Roma 0 destinado a condensar a parte geral do direito de conflitos, tendo em vista tanto a ambiciosa regulamentação das matérias ainda tendencialmente conformadas pelos diversos regimes conflituais (internos e convencionais) vigentes nos Estados-membros como, mais modestamente, a resolução dos conflitos horizontais e verticais das normas de conflitos e a integração das lacunas existentes nos instrumentos já adoptados. Aliás, a própria preferência pela conexão residência habitual, atendendo ao carácter instável desta, pelo menos quando confrontada com a nacionalidade, permite igualmente vaticinar a referida quebra da unidade do direito por força da aplicação sucessiva de variados ordenamentos jurídicos às diversas questões jurídicas que, de acordo com o artigo 25. do Código Civil, se encontram reconduzidas ao estatuto pessoal97. Por fim, também

96 Para mais desenvolvimentos, vide N. ASCENSÃO SILVA, "Do estatuto pessoal...", cit., p. 629 ss.

97 Com efeito, e numa evolução cunhada por inúmeras incertezas quanto aos diferenciados níveis de relacionamento entre os sistemas jurídicos nacionais e a ordem jurídica daquilo que viria a tornar-se na União Europeia, desde cedo lucidamente se prognosticaram as sérias dificuldades que a conexão "nacionalidade» viria a enfrentar no seio do processo de integração europeia perante o princípio da proibição de tratamento discriminatório e as exigências decorrentes da liberdade de circulação.

Seja como for, e não esquecendo as diferentes soluções que decorrem actualmente dos Tratados quanto à legitimidade e pressupostos de intervenção da União Europeia no domínio do direito internacional privado da família e das sucessões - designadamente, a partir do Tratado de Lisboa -, seguro é que se sedimentou o propósito de promoção da integração dos cidadãos europeus no país da sua 
na circunstância de a lei reguladora das convenções antenupciais nada ter a dizer relativamente à admissibilidade e vinculatividade das estipulações contratuais mortis causa nelas contidas poderíamos ver a demonstração do risco da quebra das sinergias que dentro de cada um dos ordenamentos jurídicos entretece o regime patrimonial do casamento e a regulamentação das sucessões ${ }^{98}$.

Ainda que tais receios não devam ser menoscabados, a convergência no que respeita à lei aplicável ao regime matrimonial do casamento (ou aos efeitos patrimoniais das uniões registadas) e aos pactos sucessórios não constitui hoje uma enganosa miragem ${ }^{99}$. Com

residência habitual (aludindo ao carácter "federativo" do domicílio e da residência habitual, por contraposição à nacionalidade, cf., recentemente, L. D'AVOUT, "La lex personalis entre nationalité, domicile et résidence habituelle", Mélanges en l'honneur du Professeur Bernard Audit - Les relations privées internationales, Paris: LGDJ, Lexextenso éditions, 2014, p. 30 ss.), razão pela qual assistimos nos instrumentos europeus de direito internacional privado, entretanto elaborados, ao triunfo quase incondicional da "residência habitual", confirmando-se a suposição dos observadores mais atentos da chamada comunitarização da disciplina da relações privadas internacionais e que ainda prematuramente logo vaticinaram o retrocesso da lei da nacionalidade, nomeadamente, nas situações em que não viesse a ser reconhecida às partes a faculdade electio iuris ou, de todo o modo, quando, embora esta fosse estabelecida, os interessados acabassem por não a exercer [neste sentido, P. LAGARDE, "Développements futurs du droit international privé dans une Europe en voie d'unification: quelques conjectures”, Rabels Zeitschrift für ausländisches und internationales Privatrecht, v. 68 (2004), pp. 236 ss., 243].

$98 \mathrm{Na}$ verdade, a solução conflitual portuguesa é perfeitamente compreensível num sistema que seja, por princípio, hostil à admissibilidade dos pactos sucessórios, pelo que, no contexto do Regulamento, e atendendo à tradição liberal de muitos Estados europeus que antes lembrámos, não se afigurou razoável sancionar um desvio à aplicação da lei da disposição em nome de um não unânime predomínio da funcionalidade familiar dos pactos sucessórios.

99 Temos em mente a Proposta de regulamento do Conselho relativo à competência, à lei aplicável, ao reconhecimento e à execução de decisões em matéria de regimes matrimoniais [Bruxelas, 16.3.2011 - COM (2011) 126 final, 2011/0059 (CNS)] e a Proposta de um regulamento do Conselho relativo à competência, à lei aplicável, ao reconhecimento e à execução de decisões em matéria de efeitos patrimoniais das parcerias registadas [Bruxelas, 16.3.2011 - COM (2011) 127 final, 2011/0060 (CNS)] (sobre estas iniciativas, vide, monograficamente, K. DENGEL, Die europäische Vereinheitlichung des Internationalen Ehegüterrechts und des Internationalen Güterrechts für eingetragene Partnerschaften, Tübingen: Mohr Siebeck, 2014).

No concernente à primeira destas iniciativas, o artigo $1 .^{\circ}, \mathrm{n} .^{\circ} 3$, aparta do seu âmbito de aplicação os direitos sucessórios do cônjuge sobrevivo, do mesmo modo que o Regulamento (UE) $n .^{\circ}$ 650/2012 não rege as questões relacionadas com os 
efeito, tal coincidência, que será apenas eventual, ainda que provável, nas situações em que venham a operar em tais domínios os critérios supletivos de determinação da lei competente, poderá deliberadamente ser prosseguida pelos interessados pela possibilidade que

regimes matrimoniais e com os regimes patrimoniais no âmbito das relações que a lei aplicável considere produzirem efeitos comparáveis ao casamento [artigo $1 .^{\circ}, \mathrm{n}^{\circ}$ 2 , alínea $d$ )]. Ainda assim, a preocupação em garantir a coerência das soluções não foi ignorada. Com efeito, e deixando de parte os casos em que nas duas matérias em causa se reconhece a admissibilidade dos pactos de eleição do foro (vide o artigo $5 .^{\circ}$ e ss. do Regulamento (UE) n..$^{\circ}$ 650/2012 e o artigo 5. ${ }^{\circ}$, n. ${ }^{\circ}$ 2, da Proposta), a Proposta de regulamento do Conselho relativo à competência, à lei aplicável, ao reconhecimento e à execução de decisões em matéria de regimes matrimoniais acolhe no artigo $3 .^{\circ}$ a regra segundo a qual, nos casos de dissolução do regime matrimonial por força da morte de um dos cônjuges, sempre que as autoridades de um Estado assumam competência ao abrigo do Regulamento (UE) n. ${ }^{\circ}$ 650/2012, elas serão igualmente competentes para decidirem as questões ligadas ao regime matrimonial relacionadas com o pedido. No mesmo sentido, e para além desta particular situação da extensão da competência das autoridades chamadas a decidir um pedido sucessório, destaca-se ainda a probabilidade de uma mesma lei determinar o regime matrimonial e a sucessão, atendendo desde logo à possibilidade de uma electio iuris que a Proposta reconhece (cf. os artigos $16 .^{\circ}$ e $18 .^{\circ}$ ), à semelhança, por isso, daquilo que acontece em matéria sucessória [artigo $22 .^{\circ}$ do Regulamento (UE) n. ${ }^{\circ}$ 650/2012].

Por outro lado, também na Proposta de um regulamento do Conselho relativo à competência, à lei aplicável, ao reconhecimento e à execução de decisões em matéria de efeitos patrimoniais das parcerias registadas proscreve do seu âmbito as obrigações de alimentos, as liberalidades e as sociedades entre parceiros e os direitos sucessórios do parceiro sobrevivo, mantendo-se, todavia, os esforços para evitar em caso de sucessão por morte a existência de procedimentos paralelos (artigo $3 .^{\circ}, \mathrm{n} .^{\circ}$ 1 ), conquanto se reconheça, todavia, a possibilidade de as autoridades competentes ao abrigo do Regulamento (UE) $n .{ }^{\circ}$ 650/2012 se recusarem a assumir jurisdição no respeitante aos efeitos das uniões registadas, sempre que estas sejam desconhecidas do direito interno (artigo $3 .^{\circ}, \mathrm{n} .^{\circ} 2$ ). De resto, e no que concerne à lei competente, a estrita aceitação de uma conexão territorial - o território do Estado onde a parceria haja sido registada - compromete a unicidade da lei aplicável que, em matéria de regime de bens do casamento, é desde logo viabilizada pela possibilidade de os nubentes ou cônjuges poderem exercer a sua autonomia conflitual.

Por fim, e deixando de parte a comprovação do modo como a cláusula de excepção consagrada no artigo $21 .^{\circ}$, n. $^{\circ} 2$, do Regulamento (UE) n. ${ }^{\circ}$ 650/2012 poderá potenciar - e acreditamos que sim -, ou não, a coerência da regulamentação da sucessão e do regime patrimonial relativo ao casamento ou às uniões registadas, não é despicienda a exclusão do reenvio nas duas Propostas a que nos referimos (cf., respectivamente, o artigo $24 .^{\circ}$ e o artigo $19 .^{\circ}$ ), ao contrário do que acontece em matéria sucessória (vide o artigo $34 .^{\circ}$, Regulamento (UE) n. ${ }^{\circ}$ 650/2012). Com efeito, também por aqui, e no chamamento de ordenamentos jurídicos diversos para reger os referidos estatutos, e que apresentam entre si inegáveis pontos de contacto, podemos desembocar em contradições ou desarticulações materiais que o método do dépeçage por si só já potencia. 
lhes é reconhecida pelo direito internacional privado europeu - e temos agora em vista a solução constante do artigo $166^{\circ}$ da Proposta de regulamento do Conselho relativo à competência, à lei aplicável, a reconhecimento e à execução de decisões em matéria de regimes matrimoniais - de operarem uma professio iuris. Finalmente, e atendendo à abertura conferida pelo artigo $26 .^{\circ}$, n. $^{\circ} 2$, do Regulamento (UE) n. ${ }^{\circ}$ 650/2012, estamos convictos de que, na concretização do princípio da conexão mais estreita que aí se encontra plasmado, o intérprete será conduzido a ponderar a particular conexão dos pactos sucessórios com o estatuto matrimonial, permitindo-se dessa maneira proceder a uma regulamentação equilibrada da organização patrimonial no seio do casamento, ainda que, na verdade, apenas quando aqueles contenham instituições contratuais feitas por várias pessoas.

Acresce também que, se à primeira vista seria razoável supor que o favor matrimonii que nesta matéria supostamente fundamenta o regime conflitual dos pactos sucessórios do Código Civil português esteve longe dos propósitos do legislador europeu e que tal facto se justificou pelo facto de se ter procurado no Regulamento, e como se isso fosse possível, construir um regime de direito de conflitos tendencialmente afastado das tradições jus-sucessórias dos Estados-Membros, na verdade, este situa-se antes num universo jurídico predominantemente receptivo à sucessão pactícia - e que até a consagração do princípio da autonomia da vontade, nos termos do seu artigo $25 .^{\circ},{ }^{\circ} 3$, evidencia -, de modo que, atendendo a tal amplo acolhimento, as restrições que no nosso direito material valem ainda em tal domínio se arriscam afinal a tornar-se despropositadas e anacrónicas. Aliás, e nesta óptica, é até provável que o funcionamento do regime conflitual europeu venha também nesta matéria a propulsionar a evolução convergente dos sistemas jus-sucessórios internos, mormente os daqueles Estados que se the encontram vinculados, desde logo, se considerarmos o modo como 
o desenvolvimento do acquis europeu tende a constranger a invocação da tradicional excepção de ordem pública internacional ${ }^{100}$.

Seja como for, ao afirmar-se o predomínio da autonomia dos sujeitos individuais no tangente ao modo como organizam a transmissão sucessória do seu património - ora pela quebra das limitações que os ordenamentos materiais elevam à admissibilidade dos "contratos de herança" ora pela extensão do princípio da autonomia da vontade ao direito de conflitos da sucessão voluntária, mormente contratual -, não nos achamos longe das tendências gerais da evolução contemporânea do direito matrimonial, matéria onde, como é sabido, são notórios os sinais da força crescente da autodeterminação individual a originar o afrouxamento do valor institucional do casamento e que, no direito internacional privado da família se espelha, afinal, numa certa decadência da lex familiae. De tal modo que, verdadeiramente, as soluções do Regulamento (UE) n. ${ }^{\circ}$ 650/2012 relativas à sucessão contratual refletem, afinal, a situação presente do direito da família e o peso que as pulsões individualistas ganharam no seio da vida matrimonial e que o direito não pôde deixar de assimilar.

16.2. Voltando agora a nossa atenção para o valor da continuidade transfronteiriça das situações privadas internacionais, também não nos parece que tal exigência se encontre em perigo no contexto do desenvolvimento actual do direito internacional privado das sucessões, a despeito da circunstância de à regulamentação do reenvio constante do Regulamento (UE) n. ${ }^{\circ}$ 650/2012 serem alheias as preocupações de harmonia jurídica internacional (simples ou qualificada) subjacentes às soluções que nesta matéria foram albergadas no nosso

100 Se é verdade que no Regulamento (UE) n. ${ }^{\circ}$ 650/2012 não se abdicou da consagração da cláusula de excepção de ordem pública internacional (artigo $35 .^{\circ}$ ), não devem ser olvidados os ventos que levam à afirmação de uma ordem pública europeia e que tenderá certamente a constranger, cada vez mais, a função nacionalista que preside tradicionalmente ao funcionamento de tal mecanismo de evicção da lex causae. 
Código Civil ${ }^{101}$ ou de, apesar de algumas soluções pontuais que têm um cariz validante - como antes referimos, a validade das disposições mortis causa acaba por ser promovida tanto pela negação do carácter substantivo de algumas exigências de forma especial ${ }^{102}$ como pela alternatividade dos elementos de conexão relativos à forma -, não se achar aí previsto, ao contrário daquilo que sucede por força do artigo 31. ${ }^{\circ}$, n. ${ }^{\circ}$, do Código Civil, um instituto especificamente destinado a assegurar o reconhecimento das situações constituídas no estrangeiro.

Com efeito, a uniformidade da lei aplicável encontra-se garantida, pelo menos no seio dos Estados vinculados ao Regulamento, pela existência de critérios idênticos de determinação da lei aplicável. Aliás, e independentemente disto, atendendo ao carácter automático do reconhecimento das decisões que aí se estabelece (artigo 39. n. ${ }^{\circ}$ 1), à aceitação dos actos autênticos, a que é atribuída a mesma força probatória, ou efeitos o mais próximos possível, que lhes é dada no Estado-Membro onde hajam sido exarados (artigo 59. ${ }^{\circ}$ ), e à susceptibilidade da declaração de executoriedade das decisões e dos actos autênticos ou transacções judiciais que sejam executórios no país de origem (vide, respectivamente, os artigos $43 .^{\circ}$ e ss., $60 .^{\circ}$ e $61^{\circ}$ ), tudo indica, na verdade, que, no contexto das relações dos Estados obrigados ao Regulamento, a questão da lei aplicável tende a perder muito do seu relevo, constituindo seguramente o princípio do reconhecimento mútuo um instrumento privilegiado de garantia da continuidade internacional da vida jurídica.

Ademais, e ainda que não se descure que o corpo uniforme de regras de conflitos contidas no Regulamento (UE) n. ${ }^{\circ}$ 650/2012, ao

101 Assinale-se, mais uma vez, que o reenvio é rejeitado em geral tanto na Proposta de regulamento relativo aos regimes matrimoniais (artigo $24 .^{\circ}$ ) como na Proposta de um regulamento relativo a efeitos patrimoniais das parcerias registadas (artigo $19 .^{\circ}$ ).

102 Comparem-se, mais uma vez, o artigo $63 .^{\circ}, \mathrm{n} .{ }^{\circ} 1$, do Código Civil e o artigo $27 .^{\circ}, \mathrm{n} .^{\circ} 3$, do Regulamento. 
permitir "uma regulamentação harmónica e completa da sucessão mortis causa" no seio de países da União Europeia, constitui afinal, ainda nas palavras de CARRASCOSA GONZÁLEZ103, o seu "corazón vitalizante", se a isto acrescentarmos os termos em que o referido princípio (o Annerkennungsprinzip) tem dado lugar, no âmbito do direito das pessoas e da família, a um alargado reconhecimento das situações jurídicas constituídas à luz de um dos ordenamentos dos Estados da União - decorrente da construção de um "espaço de liberdade, segurança e justiça” e enucleado tanto nas liberdades europeias como nas exigências de garantia do estatuto da cidadania europeia e de tutela dos direitos fundamentais -, e ainda que sem Roma 0, tudo leva a crer que não estaremos longe do sopro de alma que encaminhou, em matéria de estatuto pessoal, os autores do Código Civil de 1966.

Sabedora da complexidade da teia das acções intersubjectivamente significativas que compõem a existência do Homem, observava AGUSTINA BESSA LUÍS104, na sua notável lucidez, que "[a]s relações humanas são assim: fios interrompidos e retomados até que a morte venha fechar o anel em que pousaram em vão esperanças e vontades".

Ora, também no específico domínio da juridicidade, e como não poderia deixar de ser, encontramos um "fantástico rosário" de fundamentos e critérios, um enleado e de não linear desenvolvimento corpo de "elementos de um "puzzle" variável ao infinito" 105. Verdadeiramente, também isto o demonstra a evolução que procu-

103 El Reglamento..., cit, p. 24.

104 As relações humanas - I - Os quatro rios (1964), Lisboa: Guimarães Editores, 2001, p. 27.

$105 \mathrm{E}$ as palavras são de EDUARDO LOURENÇO, exactamente tendo em vista a obra que referimos ("Des-concertante Agustina: a propósito de Os Quatro Rios", $O$ Tempo e o Modo, n. ${ }^{\circ} 22,1964$, p. 112). 
rámos desenhar do regime dos pactos sucessórios e das soluções conflituais que a eles respeitam e onde se desvela que, afinal, apenas aparentemente a sucessão pactícia se libertou dos "grilhões" do direito da família. Afinal, tal como todos nós, e sem que a isso possamos assacar radicalmente um sentido pejorativo, também o direito das sucessões tem intransponíveis cárceres invisíveis. 
(Página deixada propositadamente em branco) 